\author{
UNIVERSIDADE DE SÃO PAULO \\ FACULDADE DE ZOOTECNIA E ENGENHARIA DE ALIMENTOS
}

CAROLINA FERNANDA SENGLING CEBIN COPPA

Extração de oleuropeína de folhas de oliva com solvente hidroalcoólico e efeito dos extratos sobre a estabilidade oxidativa de óleos vegetais 
CAROLINA FERNANDA SENGLING CEBIN COPPA

\title{
Extração de oleuropeína de folhas de oliva com solvente hidroalcoólico e efeito dos extratos sobre a estabilidade oxidativa de óleos vegetais
}

\author{
Versão corrigida
}

Dissertação apresentada à Faculdade de Zootecnia e Engenharia de Alimentos da Universidade de São Paulo, como parte dos requisitos para a obtenção do Título de Mestre em Ciências da Engenharia de Alimentos.

Área de concentração: Ciências da Engenharia de Alimentos.

Orientadora: Profa. Dra. Cintia Bernardo Gonçalves

\section{Pirassununga \\ 2016}


Ficha catalográfica elaborada pelo

Serviço de Biblioteca e Informaçäo, FZEAMUSP.

com os dados fornecidos pelo(a) autor(a)

Sengling Cebin Coppa, Carolina Fernanda

Extraçäo de oleuropeina de folhan de oliva com nolvente hidroalcoslico e efeito doe extrato sobre a eatabilidade oxidativa de 6leon vegetaie / Carolina Pernanda Sengling Cebin Coppa ; orientador Cintia Bernardo Gonçalvea. - - Piraasununga, 2016. $95 \mathrm{f}$.

Diasertaçăo (Meatrado - Programa de P6a-Graduação Engenharia de Alimentoa) - Faculdade de Eootecnia e Bngenharia de Al imentos, Univeraidade de șo paulo.

1. Oleuropeina. 2. Maceraçశo. 3. Extração. 4. Extrato hidroaloo6lico. 5. Batabilidade oxidativa. I. Bernardo Gonçalven, Cintia, orient. II. Titulo. 
"Foi o tempo que dedicastes à tua rosa que fez tua rosa tão importante." Antoine de Saint-Exupéry

Dedico este trabalho à minha mãe, Bernadete, e ao meu marido, Eduardo, com amor! 


\section{AGRADECIMENTOS}

Primeiramente, agradeço à Deus pelo dom da vida e por me dar a oportunidade e forças para a conclusão deste trabalho.

À minha mãe, Bernadete, que nunca deixou de acreditar em mim e está ao meu lado em todos os momentos, devo à ela tudo o que sou hoje.

Ao meu marido, Eduardo, por ser meu amigo acima de tudo, e me apoiar em minhas decisões. Obrigada por fazer parte da minha vida.

À toda minha família e aos meus amigos que sempre me trazem alegria.

Agradeço à minha orientadora, Cintia Bernardo Gonçalves, pela paciência, amizade e confiança depositada em mim ao longo deste trabalho, por ter me recebido de braços abertos e por me dar a oportunidade de realizar esta pesquisa. Muito obrigada!

À todos os meus colegas do Laboratório de Engenharia de Separações pela amizade e pelos momentos de descontração, em especial à Keila Kazue Aracava pelo auxílio durante a realização das análises. Não vou me esquecer de vocês!

Aos especialistas de laboratório, Marcelo Thomazini, Roice Eliana Rosim e Roseli Sengling Lacerda por concederem um pouco do seu tempo para me auxiliar com as análises.

À Profa Christianne Elisabete da Costa Rodrigues, por disponibilizar seus materiais e equipamentos ao longo da pesquisa.

À Profa Carmen Sílvia Fávaro Trindade, por disponibilizar o liofilizador em seu laboratório para a realização das análises.

À Profa Catarina Abdalla Gomide, por disponibilizar seu laboratório, materiais e equipamentos para a realização das análises de composição centesimal.

Ao Prof. Carlos Augusto Fernandes de Oliveira, por disponibilizar seu equipamento e reagentes de HPLC para a realização das análises de oleuropeína.

Agradeço à Profa Izabel Cristina Freitas Moraes, por disponibilizar o equipamento Rancimat e à Carla Mônaco pelo auxílio das análises. 
Agradeço às minhas amigas e companheiras ao longo deste curso de mestrado, Bruna, Marina, Marluci, Júlia, Laura, Talita, Yana. Muito obrigada pela amizade! Vocês estarão sempre em meu coração!

Agradeço à Universidade de São Paulo, professores, funcionários, amigos, que, de alguma forma estiveram ao meu lado ao longo desta caminhada.

Agradeço à empresa Chá e $\mathrm{Cia} \circledast$ que, inicialmente, forneceram as folhas de oliva para a realização das análises de oleuropeína.

Agradeço aos membros da banca pela participação e por suas importantes contribuições.

Agradeço à CAPES pela concessão da bolsa de mestrado. 


\section{RESUMO}

CEBIN COPPA, C. F. S. Extração de oleuropeína de folhas de oliva com solvente hidroalcoólico e efeito dos extratos sobre a estabilidade oxidativa de óleos vegetais. 2016. 95 f. Dissertação (Mestrado) - Faculdade de Zootecnia e Engenharia de Alimentos, Universidade de São Paulo, Pirassununga, 2016.

A oleuropeína é o composto fenólico mais abundante presente nas folhas da oliveira, sendo que muitos estudos vêm demonstrando que este composto apresenta importantes propriedades antimicrobiana, antioxidante, anti-inflamatória, entre outras, surgindo o interesse em estudos de métodos para sua extração e aplicação em produtos na área alimentícia, cosmética e farmacêutica. $\mathrm{O}$ objetivo deste estudo foi a extração da oleuropeína à partir de folhas de oliva, utilizando solvente não tóxico, para posterior aplicação dos extratos em óleos vegetais a fim de se verificar seu efeito sobre a estabilidade oxidativa dos mesmos. $O$ solvente selecionado para o estudo foi uma mistura de etanol e água (70:30, em massa, condição obtida através de um trabalho prévio), na presença de $1 \%$ de ácido acético. Em uma primeira etapa, foram realizados experimentos de extração utilizando-se as técnicas de maceração (tipo I) e ultrassom (tipo II), em diferentes condições de temperatura (20,30, 40, 50 e 60 ${ }^{\circ} \mathrm{C}$ ). Em uma segunda etapa, através de experimentos com maceração à temperatura ambiente, estudou-se o efeito da razão folhas:solvente (1:8, 1:6 e 1:3) e a influência da presença de ácido acético sobre o processo de extração (tipo III). Por fim, realizando-se a maceração na presença de ácido acético, temperatura ambiente e proporção folhas: solvente igual a 1:3, realizaram-se extrações sequenciadas a partir de uma mesma matéria-prima (tipo IV). Os resultados desses experimentos foram expressos em rendimento de oleuropeína (RO), teor de oleuropeína nos extratos (TO) e rendimento global (RG). Analisando-se os experimentos I e II, verificou-se que a temperatura não exerceu influência significativa sobre as respostas $\mathrm{RO}$, TO e RG. Além disso, verificou-se que os valores das respostas para os experimentos com a maceração foram um pouco maiores do que os valores obtidos para as extrações com o auxílio do ultrassom. Nos experimentos tipo III, em linhas gerais, observou-se a influência positiva da presença do ácido acético sobre as respostas estudadas. Verificou-se também que, na presença de ácido, o aumento da quantidade de solvente na extração conduz ao aumento de RO e RG, e à diminuição de TO. Através do experimento tipo IV, constatou-se que mesmo após quatro extrações sequenciadas, ainda não foi possível esgotar a oleuropeína da matéria-prima. Após a obtenção de todos os extratos hidroalcoólicos, selecionou-se um contendo aproximadamente $19 \%$ de oleuropeína para o estudo da 
estabilidade oxidativa em óleos vegetais (oliva e girassol) utilizando o método Rancimat. A presença de extrato aumentou em 3 horas o tempo de indução do azeite de oliva extra-virgem, e em 2 horas o tempo de indução do azeite de oliva comum. Os óleos de girassol bruto e refinado não apresentaram melhora na estabilidade oxidativa quando adicionados dos extratos. Foram realizados também testes de estabilidade oxidativa através da adição direta de folhas de oliva em pó nos azeites de oliva extra-virgem e comum. Para o azeite extravirgem, a adição das folhas não proporcionou melhora da estabilidade oxidativa, porém para o azeite comum, houve um aumento de mais de 2 horas no tempo de indução. Os resultados apresentados neste trabalho demonstraram que é possível obter extratos contendo teores significativos de oleuropeína utilizando-se um solvente renovável. Além disso, constatou-se que os mesmos podem ser utilizados como um antioxidante natural em azeite de oliva, melhorando sua estabilidade oxidativa.

Palavras-chave: Oleuropeína; maceração; extração; extrato hidroalcoólico; estabilidade oxidativa. 
CEBIN COPPA, C. F. S. Oleuropein extraction of olive leaves using hydroalcoholic solvent and effect of the extracts on the oxidative stability of vegetable oils. 2016. 95 p. M. Sc. Dissertation - Faculty of Animal Science and Food Engineering, University of São Paulo, Pirassununga, 2016.

Oleuropein is the most abundant phenolic compound present in the leaves of the olive tree, and many studies have shown that this compound has significant antimicrobial properties, antioxidant, anti-inflammatory, among others, emerging interest in studies of methods for extraction and use in products in the food industry, cosmetics and pharmaceuticals. The aim of this study was the extraction of oleuropein from the olive leaf, using non-toxic solvent, for further application of the extracts in vegetable oils in order to check its effect on their oxidative stability. The solvent selected for the study was a mixture of ethanol and water $(70: 30, \%$ mass, condition obtained from a previous study), in the presence of $1 \%$ acetic acid. In a first step, extraction experiments were conducted using maceration (type I) and ultrasound (type II) under different temperature conditions $\left(20,30,40,50\right.$ and $\left.60^{\circ} \mathrm{C}\right)$. In a second step, through experiments with maceration at room temperature, the effect of the ratio olive leaves:solvent $(1: 8,1: 6$ and $1: 3)$ and the influence of the presence of acetic acid on the process of extraction (type III) was studied. Finally, using maceration in the presence of acetic acid at room temperature and proportion olive leaves:solvent of 1:3, sequencial extractions from the same raw material (type IV) were performed. The results of these experiments were expressed in oleuropein yield (RO), oleuropein content in extracts (TO) and global yield (RG). Analyzing the experiments I and II, it was found that the temperature did not have significant influence on the $\mathrm{RO}$, TO and RG values. Furthermore, it was found the response values for the experiments with maceration was somewhat higher than values obtained for extractions using ultrasound. In type III trials, in general, a positive influence of the presence of acetic acid in the studied answers were observed. It was also found that in the presence of acid, higher amount of solvent leads to an increase of RO and RG values, and a decrease of TO value. Through the experiment type IV, it was found that even after four sequential extractions, it was not possible to exhaust oleuropein raw material. After obtaining all the hydroalcoholic extracts, na extract contanining approximately $19 \%$ of oleuropein was selected for the study of oxidative stability of vegetable oils (olive and sunflower oil), using the Rancimat method. The presence of extract increased in 3 hours the induction time of extra-virgin olive oil, and in 2 hours the induction time of common olive oil. Crude and refined sunflower oils showed no improvement in the 
oxidative stability when added to the extracts. Oxidative stability tests were also performed by direct addition of olive leaf powder in extra virgin and common olive oil. For extra virgin olive oil, the addition of the powder leaves did not improve the oxidative stability, but for the common oil, an increase of more than 2 hours in induction time was observed. Results demonstrated that it is possible to obtain extracts containing significant concentrations of oleuropein using a renewable solvent. Furthermore, it was found that it can be used as a natural antioxidant in olive oil, improving its oxidative stability.

Keywords: Oleuropein; maceration; extraction; hydroalcoholic extract; oxidative stability. 


\section{LISTA DE FIGURAS}

Figura 1: Árvore da oliveira.

Figura 2: Estrutura química dos polifenóis mais representativos da folha de oliveira (hidroxitirosol, oleuropeína, ácido elenólico, quercetina, verbascosídeo). .21

Figura 3: Estrutura química da oleuropeína. .22

Figura 4: Formação do hidroxitirosol à partir da hidrólise da oleuropeína. .24

Figura 5: Esquema dos sistemas de ultrassom: (a) banho de ultrassom indireto; (b) sonda de ultrassom; (c) banho de ultrassom direto. 31

Figura 6: Mecanismo de ação dos antioxidantes primários. .35

Figura 7: Agitador de peneiras utilizado para a análise do diâmetro médio das partículas das folhas de oliva em pó. .46

Figura 8: Extração da oleuropeína utilizando o agitador magnético. .50

Figura 9: Secagem do etanol em evaporador rotativo. .51

Figura 10: Extração da oleuropeína utilizando o banho de ultrassom. .51

Figura 11: Equipamento Rancimat. .57

Figura 12: Distribuição granulométrica das folhas de oliva em pó por difração a laser.

Figura 13: Primeira extração sequencial da oleuropeína. .70

Figura 14: Segunda extração sequencial da oleuropeína. .70

Figura 15: Terceira extração sequencial da oleuropeína. .71

Figura 16: Quarta extração sequencial da oleuropeína. .71

Figura 17: Comparação da adição de extrato e de folhas de oliva aos azeites. .78 


\section{LISTA DE TABELAS}

Tabela 1: Resultados das análises de composição centesimal das folhas de oliva em pó. .59

Tabela 2: Quantidade de folhas de oliva em pó retida em cada uma das peneiras. .60 Tabela 3: Resultados dos valores médios de densidade real, densidade aparente e porosidade do leito das folhas de oliva em pó

Tabela 4: Rendimento de oleuropeína (RO), teor de oleuropeína (TO) e rendimento global de extrato $(R G)$, para os procedimentos Tipo I e Tipo II. 63 Tabela 5: Rendimento de oleuropeína (RO), teor de oleuropeína (TO) e rendimento global de extrato $(R G)$, para o procedimento Tipo III. .66

Tabela 6: Rendimento de oleuropeína (RO), teor de oleuropeína (TO) e rendimento global de extrato $(R G)$, para o procedimento Tipo IV. 69

Tabela 7: Perfil de ácidos graxos dos azeites de oliva extra-virgem e comum, e dos óleos de girassol bruto e refinado (em massa). .72

Tabela 8: Resultados das análises de acidez dos óleos vegetais .73

Tabela 9: Resultados dos tempos de indução obtidos no aparelho Rancimat para as amostras de óleos vegetais com e sem a adição dos extratos de folhas de oliva.....75 


\section{LISTA DE ABREVIATURAS}

$\begin{array}{ll}\text { d } & \text { Diâmetro } \\ \text { dmp } & \text { Diâmetro médio das partículas } \\ \text { GAE } & \text { Equivalente de ácido gálico } \\ \text { GRAS } & \text { Generally Recognized As Safe } \\ \text { HPLC } & \text { High Perfomance Liquid Chromatography } \\ \text { nd } & \text { Não detectado } \\ \text { PLE } & \text { Líquido pressurizado } \\ \text { RG } & \text { Rendimento global de oleuropeína } \\ \text { RO } & \text { Rendimento de oleuropeína } \\ \text { TO } & \text { Teor de oleuropeína nos extratos } \\ \text { w } & \text { Fração mássica } \\ x & \text { Número de carbonos } \\ \text { y } & \text { Número de duplas ligações }\end{array}$




\section{SUMÁRIO}

1. INTRODUÇÃO

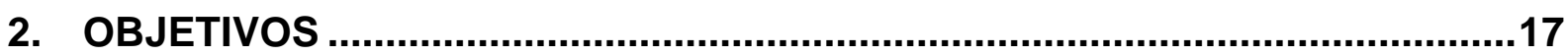

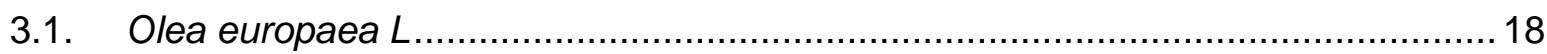

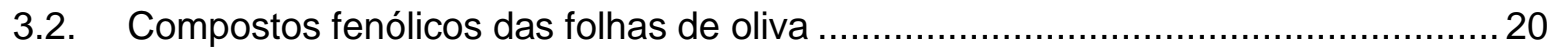

3.2.1 A oleuropeína e suas características.............................................................. 22

3.2.2. Estudos relacionados à aplicação de oleuropeína ............................................... 25

3.3. Métodos de extração da oleuropeína................................................................. 28

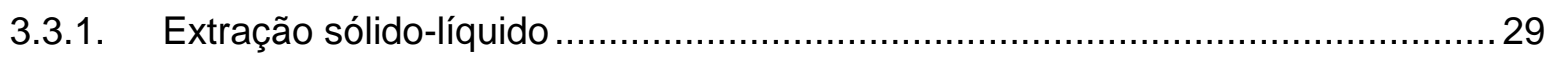

3.3.2. Extração assistida por ultrassom.................................................................... 30

3.3.3. Extração assistida por micro-ondas............................................................ 32

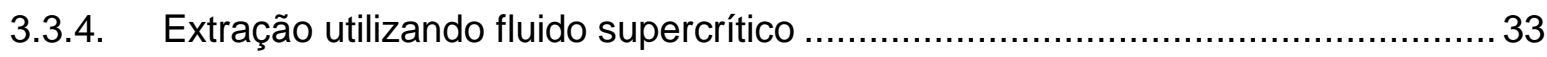

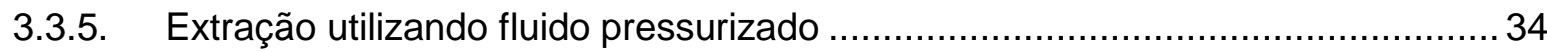

3.4. Utilização de antioxidantes naturais.................................................................. 34

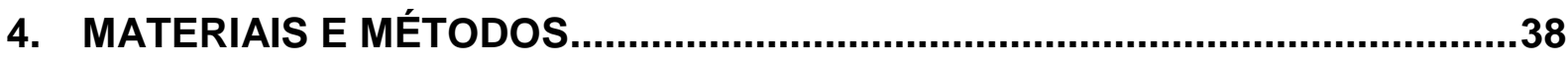

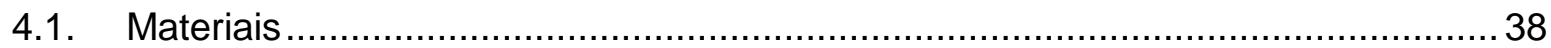

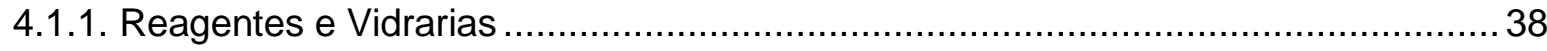

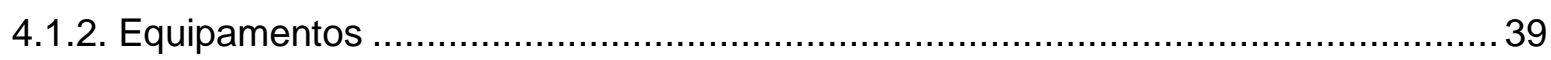

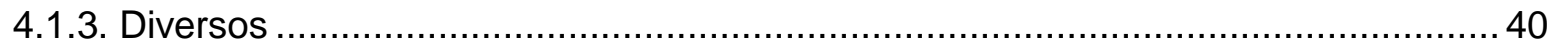

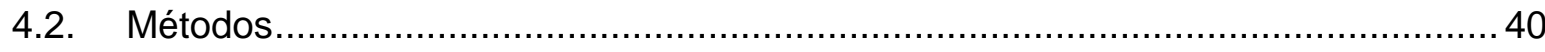

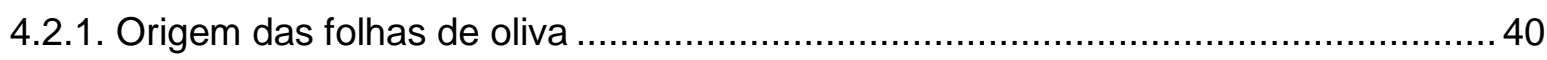

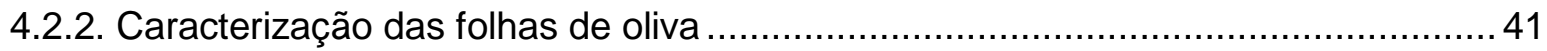

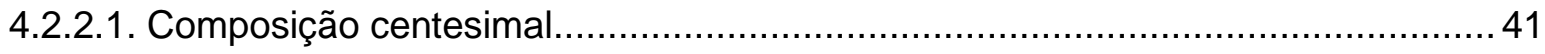

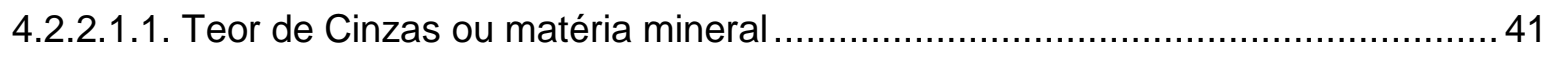

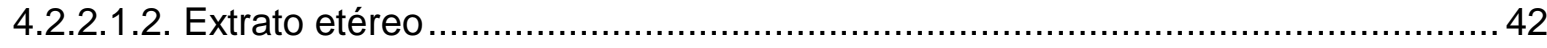

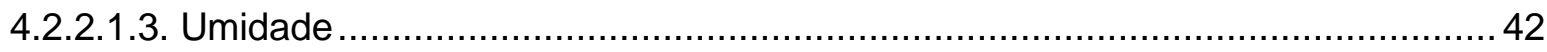

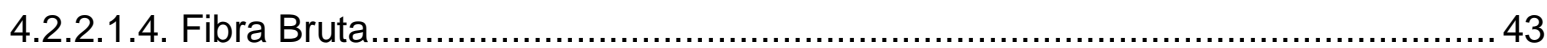


4.2.2.1.5. Nitrogênio total e proteína bruta pelo método Micro-Kjeldahl.....

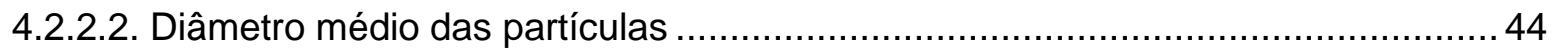

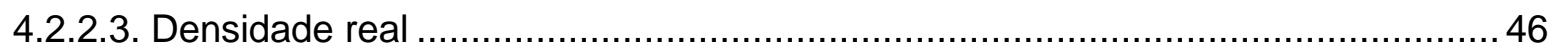

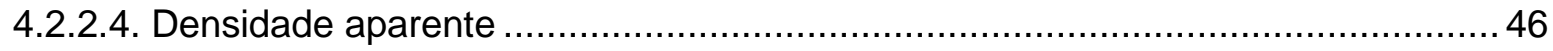

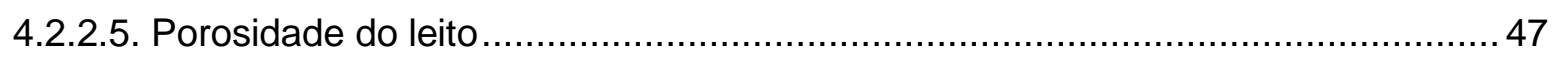

4.2.2.6. Teor de oleuropeína nas folhas de oliva ........................................................... 47

4.2.3. Experimentos para a obtenção dos extratos de folhas de oliva ............................. 48

4.2.4. Análise do teor de oleuropeína nos extratos ................................................... 53

4.2.5. Estudo da aplicação dos extratos de oleuropeína em óleos vegetais ....................53

4.2.5.1. Caracterização dos óleos vegetais utilizados no estudo ....................................54

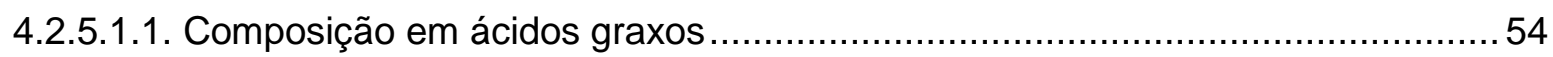

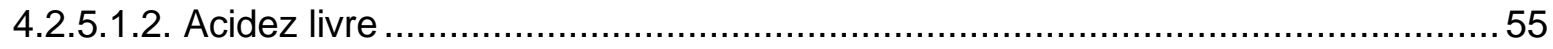

4.2.5.2. Determinação da estabilidade oxidativa ..................................................... 56

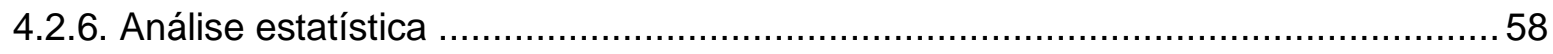

5. Resultados e discussão ...........................................................................59

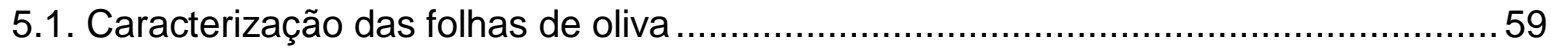

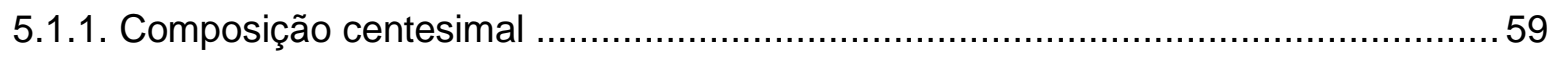

5.1.2. Diâmetro médio das partículas, densidade aparente, densidade real e porosidade 60

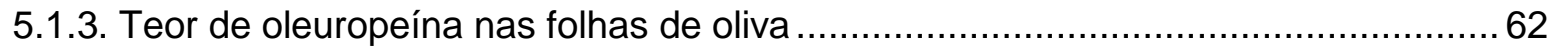

5.1.4. Experimentos de extração com solvente hidroalcoólico ..................................... 63

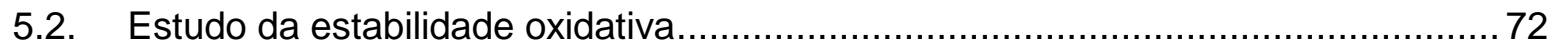

5.2.1. Caracterização dos óleos vegetais utilizados ............................................... 72

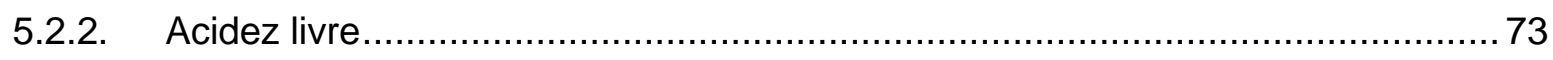

5.2.3. Aplicação dos extratos de folhas de oliva em óleos vegetais para a avaliação da

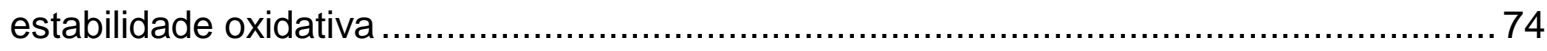

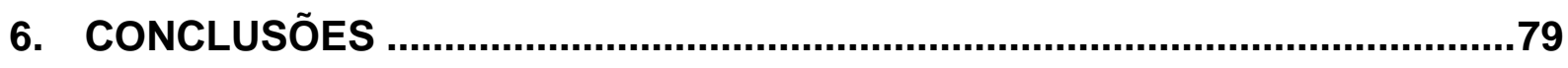

7. SUGESTÕES PARA TRABALHOS FUTUROS..............................................81

8. REFERÊNCIAS .................................................................................. 82 


\section{INTRODUÇÃO}

A oleuropeína é o composto fenólico mais abundante presente nas folhas da oliveira (Olea Europaea L.) (AOUIDI et al., 2012; AL-AZZAWIE; ALHAMDANI, 2006), sendo considerada um éster do ácido elenólico e 3,4-dihidroxifenil etanol (TAN et al., 2003) que, após a ingestão, é metabolizada para hidroxitirosol, considerado também um importante antioxidante (ZOIDOU et al., 2014). Muitos estudos vêm demonstrando que a oleuropeína apresenta importantes propriedades como antimicrobiana (TRIPOLI et al., 2005), antioxidante (VISIOLI; POLI; GALLI, 2002), antiviral (MICOL et al., 2005), anti-inflamatória (VISIOLI; BELLOSTA; GALLI, 1998), entre outras, das quais surgiram o interesse em estudos de métodos para sua extração bem como sua aplicação em produtos na área alimentícia, cosmética e farmacêutica.

A população busca cada vez mais por produtos naturais ou os que contenham produtos naturais em sua composição, fazendo com que as indústrias substituam os aditivos sintéticos presentes nos alimentos pelos naturais, aumentando 0 fornecimento de matérias-primas naturais em diversos ramos da indústria (HOCHKOEPPLER; KOFOD; ZANNONI, 1995; MOSCA et al., 2013). A detecção desse componente é realizada por meio de cromatografia líquida de alta eficiência (HPLC) (RANALLI et al., 2006), técnica que requer um preparo químico e manual das amostras a serem analisadas, além da presença de equipamentos sofisticados para a análise. Diversos métodos estão relacionados à extrabilidade desse composto, mas cada um possui suas vantagens e desvantagens que irão interferir diretamente no rendimento da oleuropeína, além de parâmetros como tipo de amostra, de solvente, temperatura, localização em que se encontra o composto de interesse e propriedades do mesmo (MUSTAFA; TURNER, 2011; XYNOS et al., 2012) devem ser analisados. Devido ao benefício que a oleuropeína pode trazer para a saúde e para os alimentos, por ser um antioxidante, estudos em relação às técnicas de extração e o efeito dos extratos nos produtos alimentícios são de extrema importância prática.

A presente dissertação de mestrado teve como objetivo o estudo da extração da oleuropeína das folhas de oliva utilizando métodos como maceração e extração assistida por ultrassom, na presença de um solvente hidroalcoólico não tóxico (etanol e água), considerados GRAS (Generally Recognized as Safe), além da aplicação dos extratos obtidos em óleos vegetais (oliva e girassol) para verificar seu efeito sobre a estabilidade oxidativa dos mesmos. 


\section{OBJETIVOS}

Esta dissertação de mestrado apresenta como principal objetivo a extração da oleuropeína à partir de folhas de oliva, além do estudo de melhores condições de extração da mesma utilizando solventes não tóxicos, para posterior aplicação dos extratos obtidos em óleos vegetais, a fim de aumentar a estabilidade oxidativa das amostras avaliadas, analisando-se o potencial antioxidante da oleuropeína como um antioxidante natural para aplicação em alimentos.

Neste contexto, para o alcance do objetivo principal, foram realizadas as seguintes etapas:

- Caracterização das folhas de oliva utilizadas nos experimentos de extração e dos óleos vegetais utilizados nos experimentos de estabilidade oxidativa;

- Realização de experimentos de extração de oleuropeína das folhas de oliva com solvente hidroalcoólico, utilizando as técnicas de maceração e com o auxílio de ultrassom, com variação de temperatura, da razão folhas:solvente, e na presença ou ausência de ácido acético;

- Aplicação do extrato com o maior teor de oleuropeína (obtido nos experimentos de extração) em óleos vegetais para o estudo da influência do composto sobre a estabilidade oxidativa das amostras de óleos analisadas. 


\section{REVISÃO BIBLIOGRÁFICA}

\subsection{Olea europaea $L$.}

A oliveira (Olea europaea L.) (Figura 1) é uma árvore frutífera classificada na família botânica Oleaceae, característica da região Mediterrânea, utilizada para fins ornamentais, produção de azeitonas de mesa e também para a produção do azeite de oliva (FARES et al., 2011; LALAS et al., 2011). Pode ser descrita como uma árvore de porte médio, apresentando troncos contorcidos, folhas com aspecto lanceolado e frutos pequenos (CRUZ et al., 2012). Algumas árvores vivem por centenas de anos (DíEZ et al., 2011) e isso está relacionado ao fato da oliveira ser resistente às alterações de temperatura, conseguindo adaptar-se em regiões quentes, no verão, e frias, no inverno (EPAMIG, 2002; VILLA; OLIVEIRA, 2012). Seu cultivo se estende por regiões de climas temperados e tropicais, principalmente nos países da costa do mar mediterrâneo, onde se encontram aproximadamente $90 \%$ dos 10 milhões de hectares cultivados em todo o mundo (COUTINHO et al., 2009).

Figura 1: Árvore da oliveira.

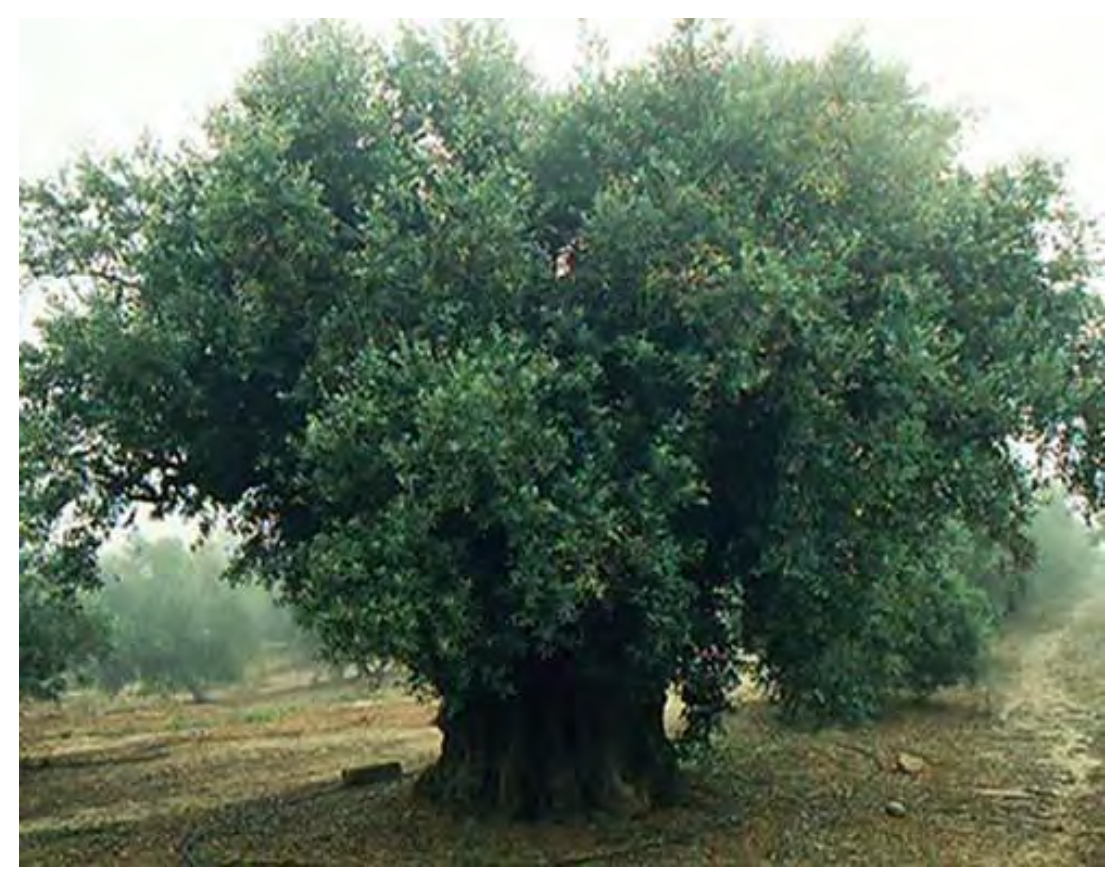

Fonte: Disponível em:<http://soareslopes.tripod.com>. Acesso em: 10 dez. 2015. 
Existem mais de 200 variedades de oliveira ao redor do mundo, muitas são idênticas, mas diferem em seus nomes dependendo da região em que são cultivadas (CABALLERO, 2012). Suas raízes podem atingir até 6 metros de profundidade, assim consegue captar os elementos do solo necessários para o seu desenvolvimento e, por isso, se diferencia das outras espécies, pois consegue resistir a períodos de seca prolongado (ARANTES, 2008). As variedades desta árvore produzem frutos com diferentes características, tamanhos, composição e sabor (RIACHY et al., 2011).

Por volta de 1800, o cultivo das oliveiras teve início em diversas regiões do país, principalmente em São Paulo, onde apresentou cultivares bem produtivos, mas que acabaram extintos no período colonial, por ordem real, para evitar que os produtos brasileiros competissem com os de Portugal. No Brasil, as variedades predominantes são a Arbequina, Grappolo, Maria da Fé, entre outras (VILLA; OLIVEIRA, 2012), sendo que algumas são destinadas à produção de azeite de oliva, que é obtido por meio da compressão direta da azeitona, como a Koroneiki, Arbequina, Arbosana e Grappolo, pois conseguem obter um alto rendimento do óleo produzido pelos frutos (EMBRAPA, 2012 apud CAVALHEIRO, 2013; OLISUL, 2012 apud CAVALHEIRO, 2013). Este processo possibilita a transferência entre os compostos que estão presentes nas azeitonas para a fração do óleo, obtendo-se um produto rico em ácidos graxos monoinsaturados, compostos fenólicos e vitaminas, permanecendo ainda o sabor e o odor característicos do fruto (RIACHY et al., 2011). Ademais, o azeite de oliva pode proporcionar efeitos benéficos à saúde, podendo atuar na redução dos riscos de doenças cardiovasculares, doenças crônicas e até mesmo, o câncer (ERBAY; ICIER, 2009; MIRANDA et al., 2010; PEREZ-JIMENEZ et al., 2005). A variedade Arbequina é uma espécie característica da Espanha, pois é mais tolerante ao frio e à salinidade (BARRANCO; FERNANDEZ-ESCOBAR; RALLO, 2008; EMBRAPA, 2012 apud CAVALHEIRO, 2013). A Arbosana possui características similares à Arbequina, com alta produtividade para o azeite de oliva (EMBRAPA, 2012 apud CAVALHEIRO, 2013) e as variedades Ascolano e Negrinha do Feijó, por exemplo, destinam-se à produção de azeitonas de mesa, por produzirem um baixo rendimento de óleo (EMBRAPA, 2012 apud CAVALHEIRO, 2013; CONFAGRI, 2013 apud CAVALHEIRO, 2013). Enfim, cada cultivar da árvore é destinado à uma determinada produção, dependendo de suas características particulares, no 
rendimento do produto destinado e necessidades para adaptação ao clima de cada região.

Além de seus frutos, suas folhas também fornecem componentes considerados essenciais para a nossa saúde, pois o interesse acerca das folhas de oliveira tem aumentado devido ao seu elevado conteúdo de polifenóis (ZAFER et al., 2008). A literatura reporta que os extratos das folhas de oliva possuem ação antioxidante, hipoglicemiante, hipotensiva, entre outras (BENAVENTE-GARCÍA et al., 2000) e essas propriedades estão relacionadas justamente ao teor dos compostos fenólicos em suas folhas (KIRITSAKIS et al., 2010). Os compostos fenólicos majoritários presentes nas folhas de oliva são a oleuropeína e seu derivado, o hidroxitirosol (ERBAY; ICIER, 2010) e, em menores concentrações, substâncias como o tirosol, o ácido caféico, luteolina, verbascosídeo, entre outras (TASIOULA-MARGARI; OLOGERI, 2001). Estas substâncias possuem uma alta capacidade de atuar como antioxidantes, sequestrando os radicais livres, podendo ser utilizadas em alimentos para prevenir a oxidação em alimentos, principalmente os compostos por lipídeos, prolongando sua vida útil (XYNOS et al., 2012).

\subsection{Compostos fenólicos das folhas de oliva}

As folhas de oliva vêm sendo comercializadas na forma de pó, podendo ser incorporadas à alimentação ou na preparação de chás e, seu chá, se revelou um agente da saúde devido à presença de polifenóis que traz benefícios até maiores que o azeite. De acordo com Abaza et al. (2007) e Bao et al. (2007), estes compostos são absorvidos no trato gastrointestinal, atingindo concentrações significativas na corrente sanguínea, o que leva este produto a ser uma alternativa aos antioxidantes sintéticos (ARANTES, 2008). Segundo Ranalli et al. (2006), os compostos fenólicos acumulamse principalmente nas folhas e nos frutos nas fases de crescimento e maturação.

Os compostos fenólicos da oliveira são chamados de polifenóis (RYANA; ROBARDS; LAVEE, 1999) e são estruturas químicas variadas, presentes nas raízes, folhas, caules e frutos da árvore. De acordo com Kajdzanoska, Petreska e Stefova (2011), as folhas de oliva possuem mais de 40 estruturas de compostos ativos fenólicos, que 
possuem elevada atividade antioxidante e potencial redox, que Ihes permitem atuar como agentes redutores, supressores de oxigênio singlet e doadores de hidrogênio.

Nas folhas estão presente 0 hidroxitirosol (3,4-DHPEA ou 3,4dihidroxifeniletanol), o ácido vanílico, o tirosol (3-hidroxifeniletanol) e o ácido caféico, considerados fenóis simples (SILVA et al., 2007) e outros de estruturas mais complexas, chamados de secoiridóides, como a oleuropeína (RANALLI et al., 2006). A oleuropeína possui uma estrutura química com um tamanho maior e é a mais abundante (JAPÓN-LUJÁN; CASTRO, 2007), possuindo sabor amargo, além de ser um fenol muito complexo (RANALLI et al., 2006).

A Figura 2 apresenta a estrutura química dos principais polifenóis presentes nas folhas de oliva:

Figura 2: Estrutura química dos polifenóis mais representativos da folha de oliveira (hidroxitirosol, oleuropeína, ácido elenólico, quercetina, verbascosídeo).

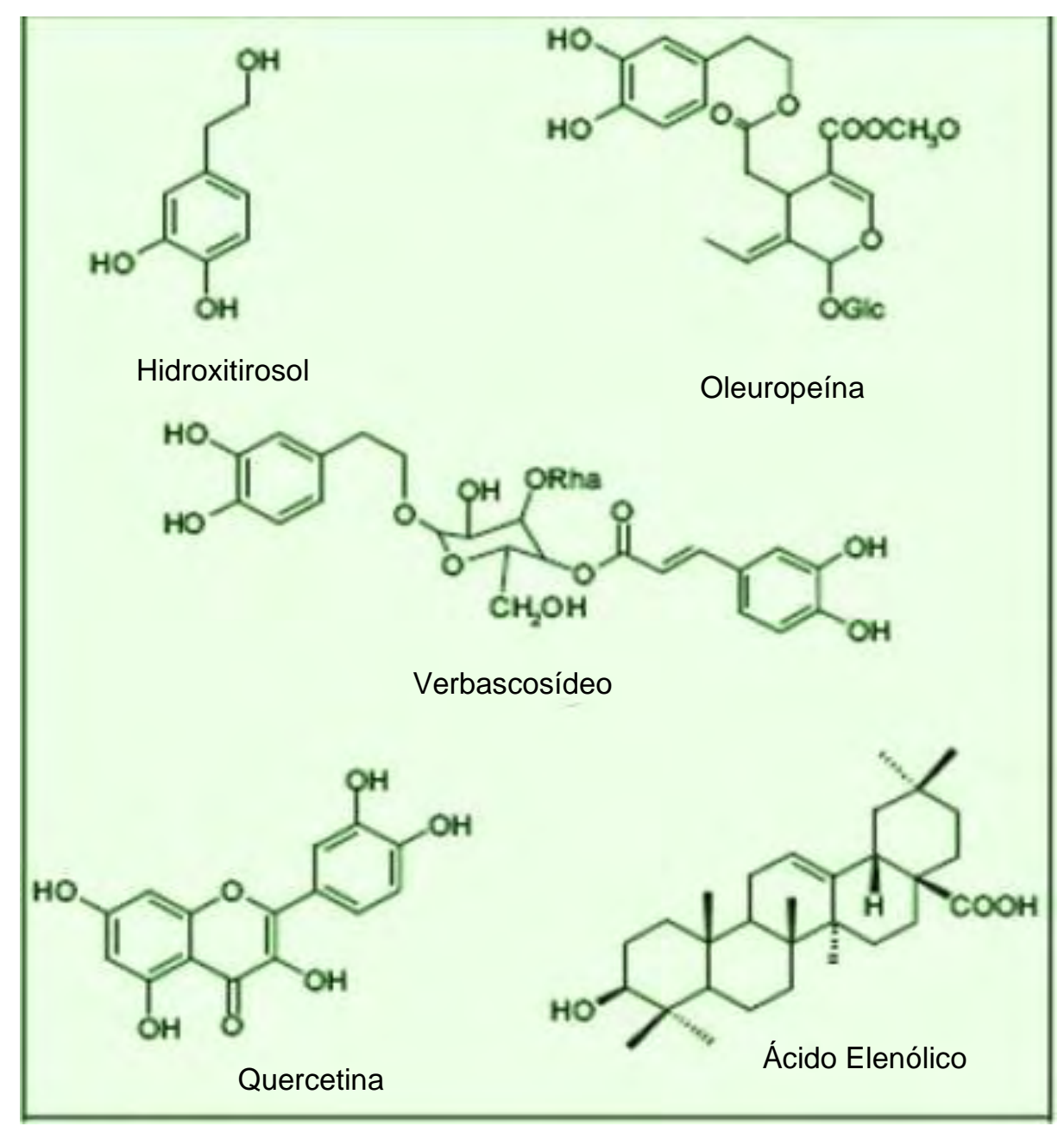

Fonte: BENAVENTE-GARCÍA, O. et al. Antioxidant activity of phenolics extracted from Olea europaea L. leaves, Research and Development Department. Food Chemistry, v. 68, 1999; SAVOURNIN, C. et al. Rapid High-Performance Liquid Chromatography Analysis for the, Quantitative Determination of Oleuropein in Olea europaea Leaves. Journal Agriculture Food Chemistry, v. 49, 2001. 


\subsubsection{A oleuropeína e suas características}

Barão (2008) descreveu a oleuropeína como um sólido fino de coloração verde, com ponto de fusão igual a $89{ }^{\circ} \mathrm{C}$ e ponto de ebulição não determinado.

A oleuropeína (Figura 3) é considerada um glicosídeo amargo (WALTER; FLEMING; ETCHELLS, 1973), que pode ser especificada como um éster heterosídico do ácido elenóico e dihidroxietanol (EFMORFOPOULOU; RODIS, 2004), além de ser o composto fenólico mais abundante presente nas azeitonas, mas praticamente ausente no azeite de oliva devido à elevada solubilidade em água e à baixa solubilidade no óleo, pela degradação enzimática que ocorre durante a produção do azeite (MARTINS; PINTO, 2008).

Figura 3: Estrutura química da oleuropeína.

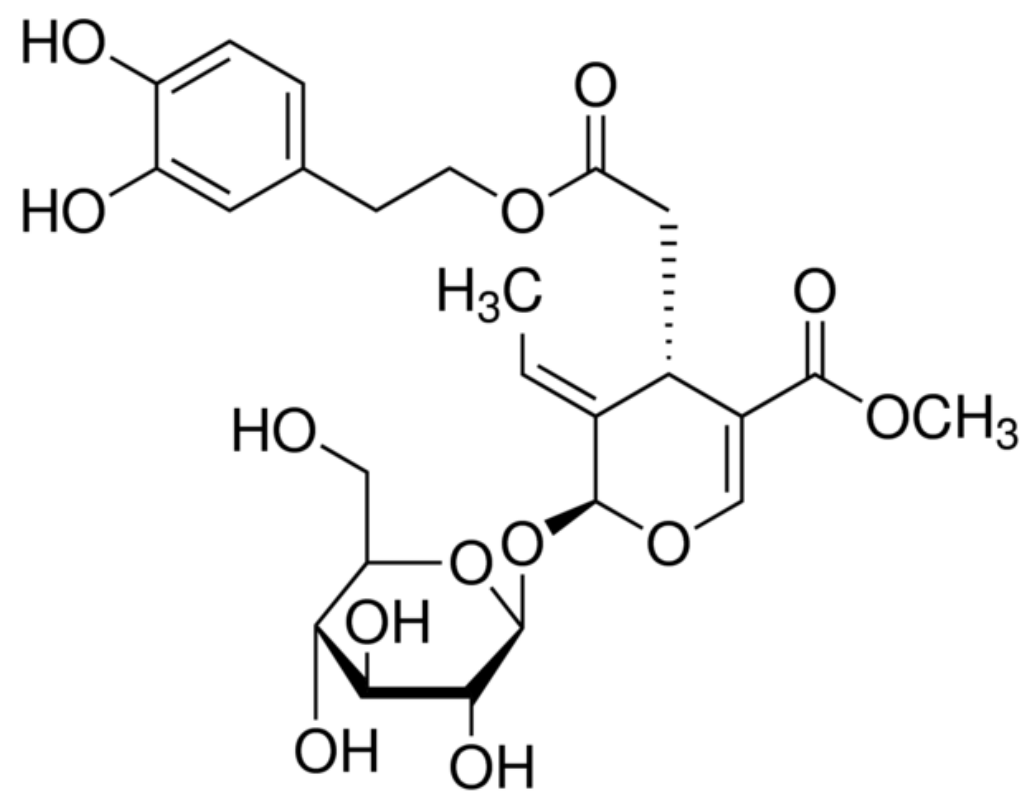

Fonte: Disponível em: < https://www.sigmaaldrich.com/united-states.html >. Acesso em: 10 abril. 2016.

Nas folhas de oliva se encontram a maior concentração de oleuropeína (aproximadamente 60-90 mg/g de folha seca) (LE TUTOUR; GUEDON, 1992), mas em todas as partes da árvore este composto está presente, porém em menor teor (JAPÓN-LUJÁN; LUQUE-RODRÍGUEZ; LUQUE DE CASTRO, 2006; PEREIRA et al., 2007). Nas azeitonas, a oleuropeína é responsável pelo sabor amargo destes frutos verdes e, ao longo se sua maturação ou da produção de azeite, ocorrem reações de 
hidrólise dos compostos fenólicos e, por isso, os compostos presentes no azeite de oliva são diferentes dos que constituem o fruto (PEDROSA, 2010).

O conteúdo de oleuropeína vai variar de acordo com a variedade, órgão, produto de oliva, clima, maturação das azeitonas no momento da colheita e o sistema de processamento que serão empregados (HASSEN; CASABIANCA; HOSNI, 2014). De acordo com Briante et al. (2004), no pó das folhas de oliva podem-se encontrar agliconas secoiridóides e glicosídeos, como a dimetil oleuropeína que, em condições de biotransformação própria, é hidrolisada em hidroxitirosol.

Este composto é conhecido também como 3,4-dihidroxifeniletanol, pertencente também ao grupo dos secoiridóides (DE LEONARDIS et al., 2008) e que também pode ser considerado um importante antioxidante presente no azeite (PEDROSA, 2010). Em sua forma nativa, o hidroxitirosol raramente está em sua forma livre, com exceção nas azeitonas em estado de maturação avançado, devido à hidrólise da oleuropeína. Naturalmente, o hidroxitirosol se forma por meio de hidrólise enzimática, com a presença específica das enzimas $\beta$-glicosidase e esterase, porém para nível laboratorial e processos industriais a hidrólise ácida é a mais utilizada (De LEONARDIS et al., 2008). Quanto mais rápido for o processo de maturação da azeitona, maior será a concentração de hidroxitirosol na polpa do fruto (ARTAJO et al., 2007). A Figura 4 representa a formação deste composto à partir da hidrólise da oleuropeína: 
Figura 4: Formação do hidroxitirosol à partir da hidrólise da oleuropeína.

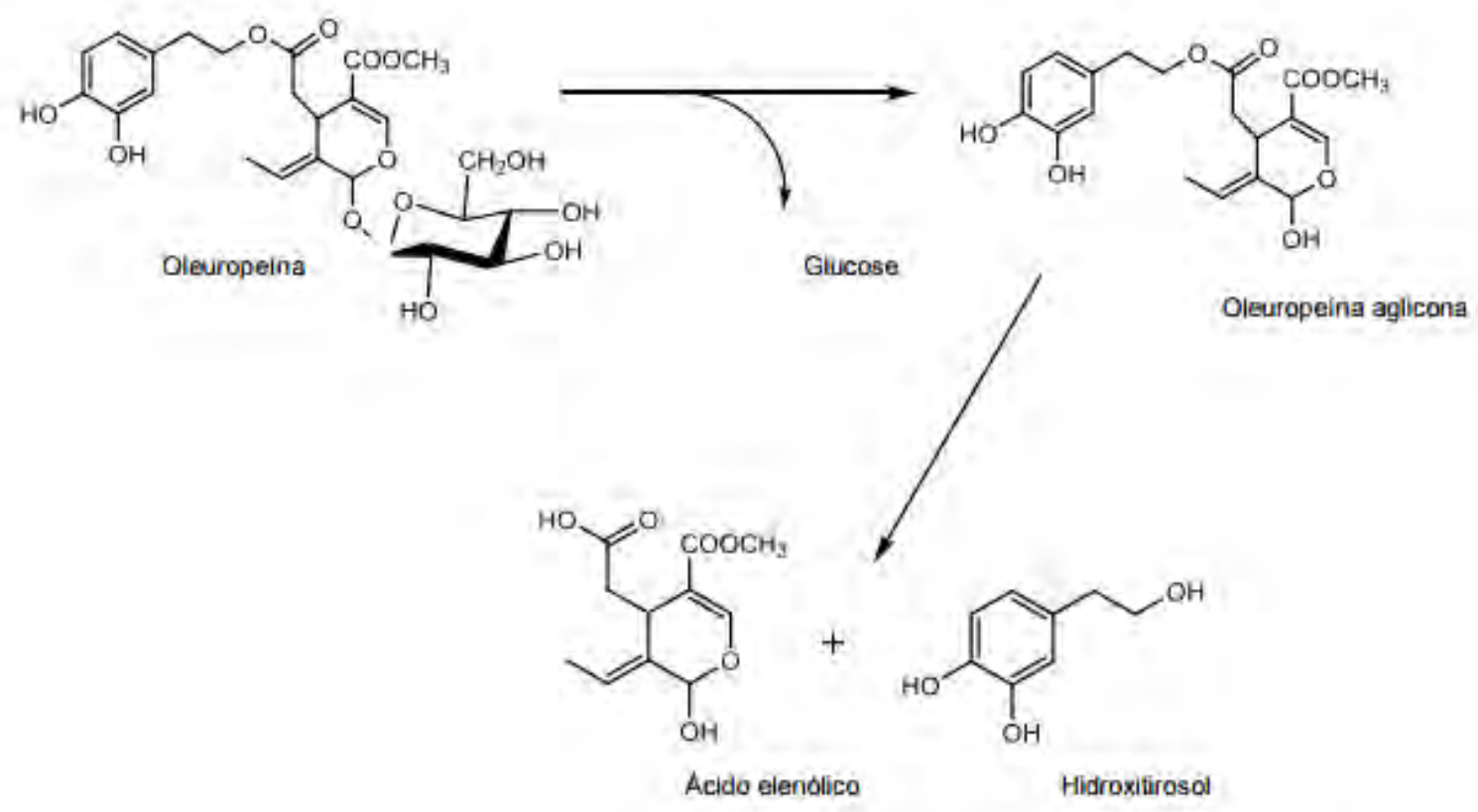

Fonte: GONÇALVES, P. M. F. Efeitos de metabólitos de fenóis do azeite no dano oxidativo em eritrócitos humanos. Dissertação (Mestrado), Faculdade de Ciências, Universidade do Porto, 2013.

Para o consumo da azeitona, esta é submetida a um tratamento com solução de hidróxido de sódio (1,0 e 2,0 \%), justamente para eliminar o sabor amargo que é provocado pela oleuropeína, mostrando-se um tratamento positivo quando a solução de hidróxido de sódio consegue atingir dois terços de profundidade na polpa da azeitona, pois ocorre a mudança de sua coloração e, em seguida, para eliminar o excesso do solvente, são realizadas várias lavagens (GAVA, 2002).

Para Japón-Luján e Castro (2007), a oleuropeína pode prevenir doenças cardíacas pois consegue proteger as membranas lipídicas da atividade oxidante, além de melhorar o metabolismo lipídico, reduzindo os problemas relacionados à obesidade, protegendo também as enzimas e as células. Acerca destas propriedades, a oleuropeína pode atuar como um antioxidante natural, possui propriedades antiinflamatórias, antimicrobiana (contra viroses, bactérias, fungos e outros parasitas) (BENAVENTE-GARCÍA et al., 2000), sendo que a elevada propriedade antioxidante que ela possui se deve à sua parte orto-difenólica presente em sua molécula. Juntos, a oleuropeína e seu derivado, o hidroxitirosol, mostram efeitos sinérgicos com a vitamina $C$ e o tocoferol (vitamina E) (GORDON; PAIVA-MARTINS; ALMEIDA, 2001; JAPÓN-LUJÁN e Castro, 2007). 


\subsubsection{Estudos relacionados à aplicação de oleuropeína}

De acordo com as informações acerca da oleuropeína apresentadas nesta pesquisa até o momento, pôde-se verificar que este composto possui diversas propriedades benéficas à saúde e, por isso, ela tem se mostrado como um forte tema para pesquisas em diversas áreas. Neste tópico serão apresentados estudos realizados com esse composto fenólico presente nas folhas de oliva, com aplicações nos mais variados ramos das indústrias.

Segundo Erbay e Icier (2010), as folhas de oliva e seus compostos estão sendo aplicados em cosméticos, na medicina, em produtos farmacêuticos, além de uma vasta exploração para aplicação na área alimentícia. Os consumidores buscam cada vez mais por produtos que combinem efeitos benéficos à saúde e que contenham um sabor desejável, porém o gosto amargo que a oleuropeína fornece representa uma séria desvantagem para sua utilização. A estabilidade do composto durante seu processo para a produção de alimentos também pode ser considerada um ponto de atenção para estudos mais profundos.

Com base nessas informações, Zoidou et al. (2014) realizaram um estudo, considerado como o primeiro relatório sobre a adição de oleuropeína no leite e iogurte para produzir novas preparações alimentícias. Os resultados indicaram que a oleuropeína apresentou resistência durante o aquecimento do leite e que, na coagulação, a oleuropeína não foi hidrolisada pela produção de ácidos, não foi metabolizada pelas bactérias do ácido láctico e não inibiu o seu crescimento. $A$ oleuropeína foi solúvel nas concentrações de $0,1 \mathrm{mg} / \mathrm{mL}$ ou $0,2 \mathrm{mg} / \mathrm{mL}$ sem adicionar qualquer gosto peculiar aos produtos. Segundo os autores, do ponto de vista tecnológico, a presença da oleuropeína não interferiu no processo do leite e do iogurte e considerando o valor biológico do composto, o mesmo pode ser adicionado como um ingrediente ativo nestes produtos para a produção de novos alimentos funcionais com benefícios à saúde.

Rodrigues, Pimentel e Oliveira (2015) propuseram aplicações na área de cosméticos para os subprodutos gerados durante a extração do azeite das azeitonas. Segundo os autores, os compostos bioativos contidos nesses subprodutos têm uma alta atividade antioxidante (especialmente a oleuropeína), perfil de ácidos graxos característico e composição mineral interessante. A aplicação cosmética poderia ser uma nova maneira de reutilizar esses subprodutos. Ingredientes naturais, 
fitonutrientes, metabólitos microbianos e componentes de proteína animal têm sido utilizados para beneficiar o envelhecimento saudável da pele (PRAKASH; MAJEED, 2009). Para os subprodutos da oliva, diferentes estudos foram realizados em relação à sua composição, mas nenhuma revisão foi apresentada sobre uma possível aplicação como ingredientes ativos na área de cosméticos (RODRIGUES; PIMENTEL; OLIVEIRA, 2015). Neste estudo, os autores sugerem que a importância dos cosméticos para o anti-envelhecimento é bem estabelecida e que muitas moléculas são promissores ingredientes "ativos" para retardar os diferentes sintomas. A sinergia, combinando o uso de cremes anti-envelhecimento com suplementos alimentares orais parece ser uma interessante abordagem para o futuro.

Afonso (2014) realizou a adição de extratos de folha de oliveira em margarina e manteiga, a fim de estudar o efeito da adição dos extratos a estes produtos com elevado teor de gordura e com uma alta susceptibilidade à oxidação, ao nível do teor em fenóis totais, atividade antioxidante e cor. De acordo com esta pesquisa, a adição de extrato de folha de oliveira não causou variações significativas no teor de fenóis totais quantificados na manteiga, mas, por outro lado, percebeu-se um aumento do teor de fenóis totais na margarina com a adição do extrato, à uma concentração de 1 $\mathrm{mg}$ de extrato/g de amostra. Para a atividade antioxidante, a margarina demonstrou forte atividade antioxidante em relação à manteiga. No parâmetro cor, houve um decréscimo de luminosidade na manteiga com a adição do extrato, enquanto que para a margarina, os resultados variaram logo após a adição e ao fim de 5 e 10 dias.

Segundo diversos estudos, há uma significativa redução em relação à utilização de BHT ou BHA em alimentos por sua ação suspeita promotora de carcinogênese, bem como a rejeição do consumo geral de aditivos alimentares sintéticos (WURTZEN OLSEN; POULSON, 1986; TSIMIDOU; BOSKOU, 1994), embora estes antioxidantes sintéticos sejam muito eficazes, mais baratos e com alta estabilidade (FARAG; ELBAROTY; BASUNY, 2003). Por conseguinte, existe um grande interesse em substituir estes compostos sintéticos por antioxidantes naturais (FARAG; MAHMOUD; BASUNY, 2007), devido à riqueza de fenóis em folhas de oliveira, que são potenciais antioxidantes naturais. Recentemente, folhas de oliveira foram misturadas com azeitonas maduras (2-3\%) antes do processamento para a produção de óleos com um sabor mais acentuado e uma maior resistência à oxidação (RANALLI et al., 2006). 
Da mesma forma, estudos focados no enriquecimento de óleos com folhas de oliveira, seus extratos e a oleuropeína têm sido realizados.

Chiou et al. (2007) estudaram óleos que foram suplementados com extratos de folhas de oliva, os quais foram utilizados na produção de batatas fritas (BOUAZIZ et al., 2008). Eles utilizaram o óleo de palma, azeite de oliva e óleo de girassol, que foram suplementados com os extratos em níveis de 120 e $240 \mathrm{mg}$ de polifenóis totais por kg de óleo, e a fritura das batatas foi realizada em todos os óleos enriquecidos e também nos não suplementados em condições domésticas. A suplementação dos óleos com os extratos de folhas de oliva conseguiu produzir batatas fritas contendo polifenóis, como a oleuropeína, e óleos de fritura que continham maior teor de polifenóis que os originais antes da suplementação. Além disso, os polifenóis pareciam ter resistido melhor ao processo de fritura quando absorvidos pelo alimento frito, do que quando permaneceram no óleo de fritura (ERBAY; ICIER, 2010). No trabalho realizado por Paiva-Martins et al. (2007), os autores tentaram melhorar a qualidade do azeite refinado no enriquecimento com os polifenóis da folha de oliveira, conseguindo comparar o azeite refinado com o azeite virgem (JAPÓN-LUJÁN; LUQUE DE CASTRO, 2008). O extrato de folhas (1 kg) foi suficiente para fortificar de 50-320 L de azeite refinado para uma estabilidade semelhante ao azeite virgem e, por isso, o sabor e a estabilidade da qualidade do produto foi aumentado (ERBAY; ICIER, 2010).

Devido à todas as propriedades benéficas da oleuropeína, muitos estudos já foram realizados também para sua aplicação na área da medicina, principalmente no tratamento de algumas doenças, e têm mostrado resultados muito positivos.

Um recente estudo cruzado randomizado e controlado por placebo foi realizado na Nova Zelândia, com 46 participantes de meia idade, com médio-alto índice de massa corporal e em risco de desenvolver a síndrome metabólica, receberam uma dose oral de oleuropeína (cerca de $50 \mathrm{mg}+10 \mathrm{mg}$ de hidroxitirosol) ou de placebo durante 12 semanas. No final do tratamento, os resultados mostraram que, em comparação com o placebo, as pessoas alimentadas com oleuropeína exibiram uma melhoria de $15 \%$ na sensibilidade à insulina e uma melhoria de $28 \%$ na capacidade de resposta de células do pâncreas e da capacidade secretora, sem qualquer efeito negativo sobre os parâmetros fisiológicos (DE BOCK et al., 2013).

Sumiyoshi e Kimura (2009) relataram em seu trabalho que as folhas de oliva têm sido muito utilizadas na medicina popular, assim como o chá de ervas na Europa 
e também na área do Mediterrâneo. O clima do mediterrâneo é caracterizado por altas temperaturas e pela forte radiação ultravioleta B (UVB), causando efeitos na pele, aumentando rugas, pigmentação e a sua espessura. Neste estudo, os autores tiveram como objetivo examinar os efeitos de um extrato de folha de oliveira e de seu componente, a oleuropeína, aos danos à pele causados pela radiação UVB aguda em camundongos. O extrato de folha de oliveira (300 ou $1000 \mathrm{mg} / \mathrm{kg}$ ) e a oleuropeína (25 ou $85 \mathrm{mg} / \mathrm{kg}$ ) foram administrados oralmente, duas vezes ao dia, durante 14 dias. A UVB foi administrada diariamente a uma dose de $120 \mathrm{~mJ} / \mathrm{cm}^{2}$ para os primeiros 5 dias e, em seguida, a cada 2 dias, durante 9 dias. Ambos os tratamentos inibiram os aumentos na espessura da pele induzidas por radiação.

Em um outro estudo realizado por Haloui et al. (2010), os autores apresentaram que as folhas de oliva são utilizadas na medicina popular da Tunísia para tratar muitos tipos de inflamação e infecções bacterianas, como icterícia, otite, gengivite e tosse.

\subsection{Métodos de extração da oleuropeína}

Entende-se por extração de produtos naturais retirar, seletivamente e o mais completo possível, os compostos ou a fração de interesse presente no material vegetal (SONAGLIO et al., 2007). A seleção de métodos de extração de compostos que possuem propriedades farmacológicas é considerada uma das etapas mais críticas em meio às pesquisas com produtos naturais (XYNOS et al., 2012 ), pois a eficiência desse processo vai depender de alguns parâmetros, como o tipo de amostra, tipo de substâncias a serem extraídas, localização das mesmas no material vegetal (MUSTAFA; TURNER, 2011), tipo de solvente extrator (XYNOS et al., 2012), o método e a temperatura de extração utilizados (GALANAKIS; TORNBERG; GEKAS, 2010), entre outros.

Portanto, este tópico tem por objetivo apresentar alguns métodos que podem ser utilizados para a extração da oleuropeína à partir das folhas de oliva, a fim de conhecer qual técnica melhor se aplicaria à sua extração, para a obtenção de um bom rendimento e menores perdas de seus compostos 


\subsubsection{Extração sólido-líquido}

De acordo com Falkenberg, Santos e Simões (2007), a extração sólido-líquido empregando solventes orgânicos, como etanol, metanol, clorofórmio e acetato de etila, por exemplo, é uma das técnicas mais utilizadas para a obtenção de compostos não voláteis. Várias técnicas podem ser aplicadas, tais como extrações a frio, empregando maceração, percolação ou turbo extração. Há também as extrações a quente que podem ser realizadas em sistemas fechados, como a extração utilizandose o aparelho de Sohxlet, ou em sistemas abertos, como nos métodos de decocção ou infusão.

Em amostras sólidas, neste processo, uma das primeiras ações a se fazer é a realização da transferência dos analitos de interesse para a fase líquida, no caso, o solvente extrator adequado (CASTRO; CAPOTE, 2010). A extração sólido-líquido pode ser chamada também de lixiviação, e é uma das técnicas mais antigas utilizadas para esse tipo de processo (CASTRO; GARCIA-AYUSO, 1998; MILIC et al., 2013). Já a maceração é um exemplo de extração sólido-líquido empregada para a obtenção de compostos fenólicos à partir de fontes vegetais. Este é considerado um processo simples, pois consiste em empregar calor e/ou agitação a fim de realização a dissolução das substâncias presentes na amostra sólida para o solvente extrator. Porém, apesar de ser uma técnica simples, muitas vezes os rendimentos dos compostos obtidos são baixos, e o tempo de extração pode levar algumas horas (CASTRO; GARCIA-AYUSO, 1998; CASTRO, CAPOTE, 2010).

Na pesquisa realizada por Jimenez et al. (2011), os autores escaldaram à $95^{\circ} \mathrm{C}$ as folhas de oliveira durante 4,5 minutos, as quais foram resfriadas em seguida com jatos de água fria, para que as mesmas fossem secas à uma temperatura de $45^{\circ} \mathrm{C}$ por 18 horas. Cerca de 760 gramas das folhas secas foram moídas e maceradas em etanol e água (1:1), por 24 horas à temperatura ambiente. Os autores encontraram nos extratos hidroalcoólicos cerca de $29 \%$ de oleuropeína e alguns de seus derivados.

Em outro estudo realizado por Sahin, Bilgin e Dramur (2011), os autores estudaram processos de extração de compostos fenólicos à partir de fontes vegetais, por meio de fluido supercrítico e Soxhlet. O maior rendimento encontrado foi a extração através do Soxhlet, onde foi avaliado vários tipos de solventes (hexano, água, metanol, etanol e a mistura de metanol/hexano (3:2, v/v), com um rendimento 
de oleuropeína de $37,84 \mathrm{mg} / \mathrm{g}$ de folha seca para a condição utilizando o metanol como solvente.

\subsubsection{Extração assistida por ultrassom}

O método de extração empregando o banho de ultrassom também pode ser considerado uma técnica simples, devido à facilidade do manuseio do equipamento. Este processo consiste em colocar o material sólido em contato com o solvente escolhido dentro de um banho de ultrassom, podendo-se controlar o tempo de extração e a temperatura desejados (KLEJDUSA et al., 2009; GARCIA-SALAS et al., 2010). Um dos fenômenos que este equipamento pode produzir é chamado de cavitação (ESCLAPEZ et al., 2011), o qual promove a formação de cavidades, que é para onde os gases dissolvidos no sistema migram, fazendo com que ocorra a formação de microbolhas que podem aumentar ou diminuir de tamanho, ocasionando a geração de ciclos de expansão e compressão dessas bolhas, até que estas implodem, liberando calor e exercendo altas pressões próximas à região da implosão (CASTRO; CAPOTE, 2007; CARCEL et al., 2012; VEILLET; TOMAO; CHEMAT, 2010).

No interior do sistema, ocorrem colisões que fazem com que as células vegetais sejam rompidas, facilitando assim a difusão do solvente para dentro da matriz vegetal (CASTRO; CAPOTE, 2007). Com isso, torna-se possível agitar a mistura e extrair os compostos ao mesmo tempo e em um tempo menor que os outros métodos, além de se utilizar baixa quantidade de solventes (CHEMAT; HUMA; KHAN, 2011; VILKHU et al., 2008).

Na maioria das vezes, a faixa ideal da frequência para o banho de ultrassom está entre as faixas de 20 à $40 \mathrm{kHz}$, mas frequências menores como as de $20 \mathrm{kHz}$ são mais eficazes para a extração de substâncias provenientes de fontes vegetais (SHIRSATH; SONAWANE; GOGATE; 2012).

A técnica de extração por meio do ultrassom tem crescido bastante na área de alimentos, pois pode ser utilizada para a extração de vitaminas, como A, D e E, por exemplo, extração de polissacarídeos, compostos antioxidantes, fenóis, etc. (LUQUEGARCÍA; CASTRO, 2003; YANG; ZHANG, 2008). Em outras áreas, esse equipamento é muito utilizado também para a remoção de sujidades em superfícies, 
principalmente na descontaminação do local, porque consegue remover as bactérias e as sujidades da superfície, alcançando partes de difícil acesso (MASON; PANIWNYK; LORIMER, 1996; VALERO et al., 2007).

A Figura 5 representa o funcionamento de um banho de ultrassom:

Figura 5: Esquema dos sistemas de ultrassom: (a) banho de ultrassom indireto; (b) sonda de ultrassom; (c) banho de ultrassom direto.

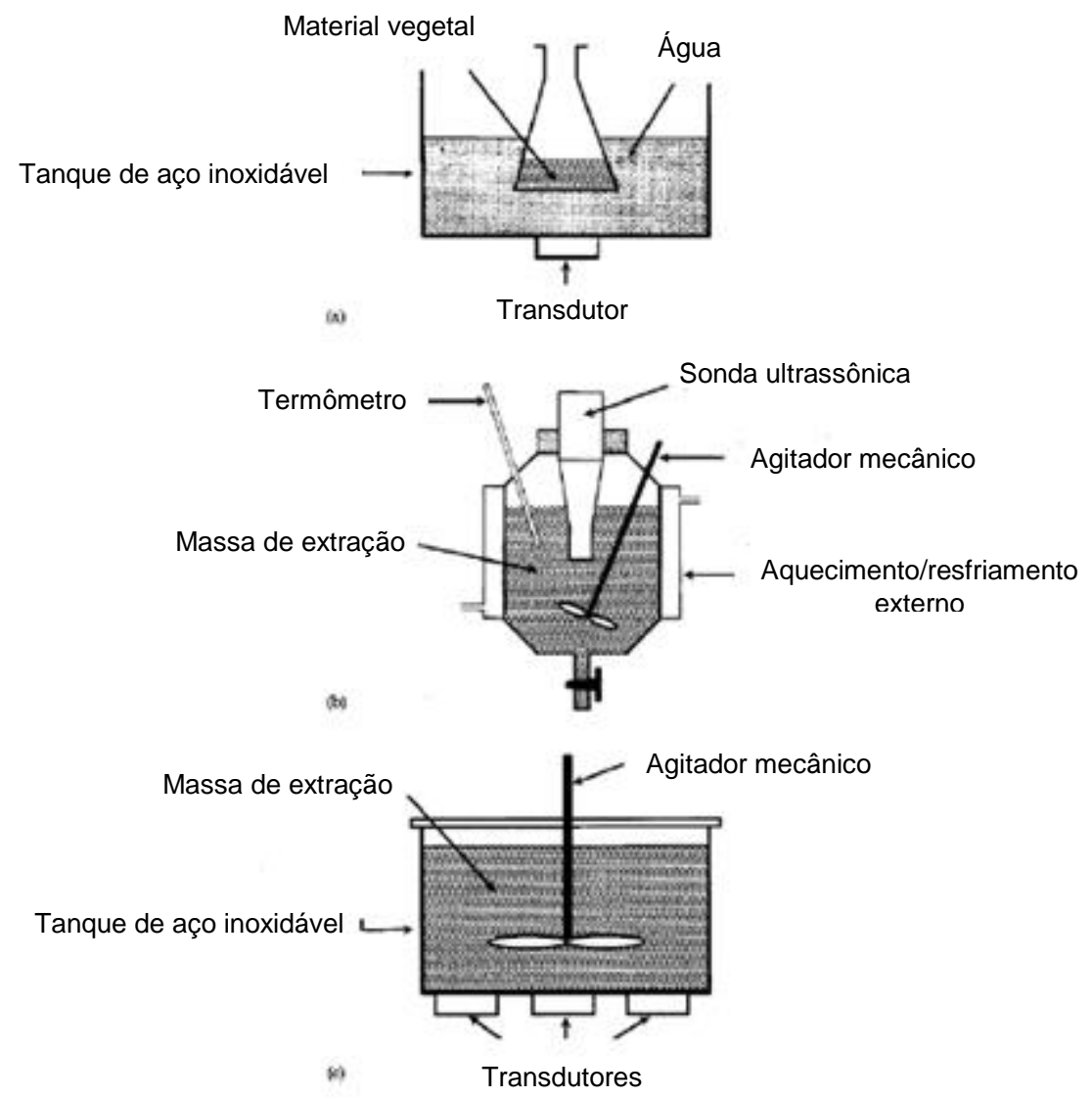

Fonte: Adaptado de VINATORU, M. et al. The use of ultrasound for the extraction of bioactive principles from plant materials. Ultrasonics Sonochemistry, v. 4, 1997.

Utilizando a maceração das folhas de oliva por meio de banho de ultrassom, Achat et al. (2012) conseguiram obter bons rendimentos de compostos fenólicos que seriam, posteriormente, adicionados ao azeite de oliva. Condições de extração como $60 \mathrm{~W}$ de energia ultrassônica, $16^{\circ} \mathrm{C}$ de temperatura e um período de 45 minutos de extração, levaram à obtenção de $414,3 \pm 3,2 \mathrm{mg}$ de equivalente de oleuropeína/Kg de 
óleo, sendo que estas condições do banho de ultrassom resultaram em bons rendimentos quando comparados à maceração simples.

Em um outro estudo feito por Xie et al. (2013), os autores estudaram a extração da oleuropeína à pressão reduzida com a ajuda de ultrassom. As melhores condições para a extração do composto foram: concentração de etanol igual a $75 \%(\mathrm{v} / \mathrm{v})$, temperatura de extração igual a $50{ }^{\circ} \mathrm{C}, 600 \mathrm{~W}$ de energia do ultrassom, tempo de extração de 3 minutos, proporção líquido/sólido igual a $30: 1(\mathrm{~mL} / \mathrm{g})$ e pressão de extração igual a $25 \mathrm{kPa}$, as quais proporcionaram um rendimento total de oleuropeína de 7,67 $\pm 0,02 \%$ após três extrações. Em comparação com as outras técnicas, esta apresentou menor tempo de extração e maior rendimento do composto.

\subsubsection{Extração assistida por micro-ondas}

A extração assistida por micro-ondas é um processo pelo qual a energia de micro-ondas pode ser utilizada para aquecer os solventes que estão em contato com as amostras sólidas e, assim, conseguir compartilhar os compostos de interesse na extração entre o material sólido e o solvente (LUQUE-GARCÍA; LUQUE DE CASTRO, 2003). Segundo Merdassa, Liu e Megersa (2014) e Ghassempour et al. (2008), há uma grande procura de métodos de extração que sejam adequados e que se encaixem na extração de produtos naturais, podendo-se utilizar solventes seguros e em baixas temperaturas.

Em um estudo realizado por Japón-Luján, Luque-Rodríguez e Luque de Castro (2006), realizarou-se a extração da oleuropeína das folhas de oliva utilizando a técnica de micro-ondas, em uma mistura de etanol e água (80:20, v/v), conseguindo um teor igual a 2,3\% do composto, além de demonstrar que os extratos obtidos podem ser injetados diretamente em cromatógrafo líquido de alta eficiência, pois os extratos são limpos. Assim, conseguiu-se reduzir o tempo da análise, além da utilização do etanol como solvente, que é não tóxico.

Taamalli et al. (2012) avaliaram a extração de compostos fenólicos das folhas de oliveira utilizando micro-ondas, a fim de otimizar algumas condições que melhor extrairiam os compostos, como tipo e composição do solvente, a temperatura do micro-ondas e tempo de extração. As melhores condições encontradas foram a mistura de metanol:água $(80: 20, \mathrm{v} / \mathrm{v})$ como solvente da extração, temperatura de $80^{\circ} \mathrm{C}$ 
do equipamento durante 6 minutos, com um rendimento final de $16,7 \%$ para os compostos fenólicos.

\subsubsection{Extração utilizando fluido supercrítico}

De acordo com Salas et al. (2010), a extração empregando fluido supercrítico pode ser considerada uma técnica de uso crescente, pois apresenta algumas vantagens se comparada aos outros métodos mais tradicionais, tais como o uso de baixas temperaturas, menor consumo de energia e elevada qualidade do produto obtido.

Nesta técnica, algumas vantagens em relação à compatibilidade ambiental, melhor seleção e baixa necessidade para a utilização de solventes orgânicos são oferecidas, além de se obter baixos níveis de degradação dos compostos químicos (REVERCHON; DE MARCO, 2006; EL; KARALAYA, 2009). A extração por fluido supercrítico empregando dióxido de carbono $\left(\mathrm{CO}_{2}\right)$ é a mais utilizada e eficaz para se isolar compostos naturais, especialmente os apolares, por isso sua aplicação em produtos naturais vem crescendo cada vez mais (LANG; WAI, 2001; IGNAT; VOLF; POPA, 2011).

Uma das desvantagens dessa técnica com $\mathrm{CO}_{2}$ como fluido supercrítico é a sua natureza não-polar, fazendo com que ele não favoreça a extração de compostos polares (DUARTE, 2011). Segundo Herrero, Cifuentes e lbañes (2006), a extração com o fluido supercrítico utiliza altas pressões, requerendo equipamentos muito caros, o que acaba encarecendo o custo do produto final.

Xynos et al. (2012) realizaram um estudo analisando a extração de folhas de oliveira por meio de fluido supercrítico, utilizando solventes não-tóxicos, $\operatorname{como} \mathrm{CO}_{2}$, água e etanol. Os autores conseguiram obter um teor de $30 \%$ de oleuropeína no extrato seco (equivalente à recuperação de $5,1 \%$ do conteúdo original presente nas folhas de oliveira) com $20 \%$ de etanol como co-solvente e $\mathrm{CO}_{2}$ supercrítico, à pressão de 300 bar. 


\subsubsection{Extração utilizando fluido pressurizado}

A obtenção de extratos a partir de matrizes vegetais por meio de fluido pressurizado possui como vantagem a rapidez e por ser um método eficiente para esse tipo de extração. Os solventes pressurizados para esse processo têm propriedades físico-químicas que podem ser ajustadas alterando-se a temperatura e a pressão, permitindo melhor controle do poder de solubilização e da seletividade do solvente no decorrer do processo (PRONYK; MAZZA, 2009).

De acordo com Richter et al. (1997), o fluido pressurizado pode ser aquecido a altas pressões e temperaturas abaixo das críticas, processo este que permite que 0 solvente possa existir em sua forma líquida mesmo quando a temperatura estiver elevada, ou seja, acima de sua temperatura de ebulição. Quando aplica-se ao etanol ou a água, por exemplo, pressões de 200 bar e temperaturas de até $200^{\circ} \mathrm{C}$, aproximadamente, o fluido ainda se mantém no estado líquido, apesar de sua temperatura atuar acima da faixa de ebulição nas condições atmosféricas. Em processo de extração, esta técnica permite melhor solubilidade dos compostos de interesse a serem extraídos, além de uma aceleração da cinética de dessorção dos compostos da fonte vegetal.

Lozano-Sánchez et al. (2014) realizaram um estudo para recuperação de compostos bioativos de folhas de oliva por meio de técnicas avançadas de extração. Os autores avaliaram o potencial de subprodutos gerados durante a filtragem do azeite extra-virgem utilizando a extração por líquido pressurizado (PLE) com uma mistura de solventes (etanol e água) à temperaturas variando entre 40 à $175^{\circ} \mathrm{C}$. A composição fenólica dos extratos obtidos com a PLE foi obtida por cromatografia líquida de alta eficiência (HPLC), sendo que os principais compostos encontrados foram o hidroxitirosol e a oleuropeína. Com isso, os autores puderam concluir que a metodologia de PLE, utilizando etanol e água a $120^{\circ} \mathrm{C}$, demonstrou um grande potencial para extrair compostos fenólicos.

\subsection{Utilização de antioxidantes naturais}

Os antioxidantes, tanto os sintéticos quanto os naturais, têm por objetivo sequestrar os radicais livres responsáveis pela oxidação dos alimentos. Os compostos 
antioxidantes, como por exemplo, polifenóis, flavonóides e ácidos fenólicos resgatam os radicais livres (hidroperóxidos, peróxidos) e retardam seus mecanismos de oxidação, responsáveis pela redução da vida de prateleira dos alimentos (DUARTE, 2011).

No início da década de 80 , houve um crescimento da procura por antioxidantes naturais, devido aos estudos sobre os efeitos negativos que os antioxidantes sintéticos (como o BHA, BHT e o TBHQ) poderiam causar à saúde quando ingeridos em doses elevadas (DURÁN; PADILLA, 1993). Com isso, foi dada mais ênfase na identificação de novos compostos oriundos de fontes vegetais e que possuíam atividade antioxidante, e que conseguissem atuar sozinhos ou em conjunto com outros aditivos, como opção para prevenir a oxidação dos alimentos e reduzir a utilização de antioxidantes sintéticos (POKORNÝ, 1991).

Os compostos fenólicos são considerados antioxidantes primários e podem promover ou inativar os radicais livres que são formados no período de iniciação ou propagação da reação, por meio da doação de átomos de hidrogênio às moléculas, fazendo com que a reação em cadeia seja interrompida (SIMIC; JAVANOVIC, 1994).

A Figura 6 representa o mecanismo de ação de um antioxidante primário, apresentado por Frankel (1980):

Figura 6: Mecanismo de ação dos antioxidantes primários.

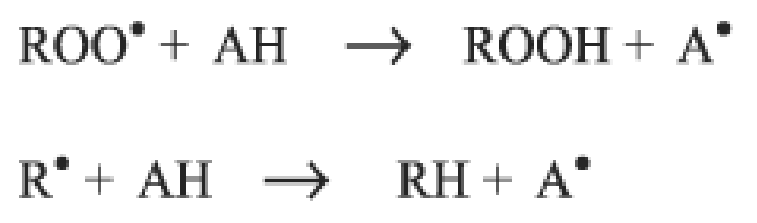

Sendo: $\mathrm{ROO} \cdot \mathrm{e} \mathrm{R} \bullet \boldsymbol{~ = ~ r a d i c a i s ~ l i v r e s ; ~} \mathrm{AH}=$ antioxidante com um átomo de hidrogênio ativo; $A$ = radical inerte.

Fonte: RAMALHO, V. C.; JORGE, N. Antioxidantes utilizados em óleos, gorduras e alimentos gordurosos. Química Nova, v. 29, n. 4, 2006.

Segundo Rafecas et al. (1998), para a escolha de um antioxidante, alguns fatores devem ser levados em consideração, como a legislação, o custo e a preferência do consumidor em relação aos antioxidantes naturais. 
Os antioxidantes fenólicos têm a função de atuar como sequestradores dos radicais livres nas etapas de iniciação e propagação do processo de oxidação, como já foi dito anteriormente e, além disso, os produtos intermediários que são formados devido à ação destes compostos fenólicos são estáveis, pois ocorre ressonância do anel aromático destas substâncias (NAWAR; FENNEMA, 1985).

Pesquisas realizadas por Ahmad-Qasem et al. (2015), demonstraram que a procura por antioxidantes naturais em alimentos, cosméticos e fármacos levaram a buscas também por estratégias que pudessem aumentar a estabilidade oxidativa dos produtos. Devido à isso, neste trabalho, os autores verificaram a influência da secagem e do armazenamento de extratos de folhas de oliva sob a estabilidade dos polifenóis e de seu potencial bioativo. Para esta avaliação, as folhas de oliva foram secas com ar quente à $120^{\circ} \mathrm{C}$ e liofilizadas, sendo que os extratos foram obtidos através de maceração, utilizando a mistura de etanol:água $(80: 20, \mathrm{v} / \mathrm{v})$ e, posteriormente, parte dos extratos foram secos com ar quente novamente, à $120^{\circ} \mathrm{C} \mathrm{e}$ desidratadas à $55^{\circ} \mathrm{C}$, sob vácuo. Desta forma, os autores puderam avaliar tanto os extratos líquidos quanto os extratos secos, armazenando-os em temperaturas de 4 , 25 e $35^{\circ} \mathrm{C}$, por um período de 4 semanas. Durante este tempo, avaliou-se os extratos quanto à capacidade antioxidante, teor de compostos fenólicos e a concentração destes compostos, e os resultados mostraram que a secagem das folhas de oliva influenciou tanto na composição do extrato em sua forma inicial, como em seu potencial bioativo no período de armazenamento. A desidratação dos extratos reduziu a capacidade antioxidante e conteúdo fenólico em $10 \%$, porém, em termos de caracterização fenólica, não foram encontradas diferenças significativas nos tratamentos utilizados. $O$ estudo pôde concluir que o armazenamento dos extratos de folhas de oliva como potencial antioxidante natural, por pelo menos 4 semanas, pode ser considerado estável, tanto líquido como pó, mostrando-se como uma grande alternativa em substituição aos antioxidantes sintéticos.

Em um outro estudo realizado por Chaicouski et al. (2014), os autores avaliaram a capacidade antioxidante da erva-mate, também em extratos líquidos e secos, determinando seu conteúdo fenólico e perdas durante a secagem por foammat drying (técnica conhecida como secagem em camada de espuma) e a liofilização. Para as extrações, os autores utilizaram água e solução de álcool etílico 70 \% e para produzir a espuma foam-mat foram utilizados pectina, emustab $\AA$ e liga neutra®. Cerca 
de 3,2 $\mathrm{g}$ de compostos fenólicos foram extraídos em meio hidroalcoólico e 1,47 g para o meio aquoso (extratos líquidos). Já para os extratos secos obtidos segundo o método foam-mat foram de $0,41 \mathrm{~g} / \mathrm{Kg}$ e $0,97 \mathrm{~g} / \mathrm{Kg}$ para os extratos secos aquoso e hidroalcoólico, respectivamente. De acordo com os resultados encontrados neste trabalho, os autores concluíram que melhores resultados de teores fenólicos foram obtidos através do extrato seco hidroalcoólico, se comparado ao aquoso, pois utilizando-se da extração com etanol consegue-se extrair tantos compostos polares quanto os menos polares, além de demostrar também que o processo de liofilização é um método considerado eficiente para a preservação dos compostos fenólicos presentes em fontes vegetais, utilizando-se de baixa temperatura e pressão, revelando-se como alternativa de extração para posterior utilização de seus compostos fenólicos como potenciais antioxidantes naturais. 


\section{MATERIAIS E MÉTODOS}

\subsection{Materiais}

\subsubsection{Reagentes e Vidrarias}

Foram utilizados os seguintes reagentes e vidrarias para a realização dos experimentos:

- $\quad$ Folhas de oliveira orgânicas certificadas (Chá e Cia®);

- Água destilada e deionizada;

- $\quad$ Ácido acético (Synth, pureza > 99\%);

- Oleuropeína padrão (Sigma-Aldrich, pureza: >80\%,)

- (Hidróxido de Sódio (Synth, pureza $\geq 97,0 \%$ );

- Reagente de esterificação $\mathrm{BF}_{3}$ (Merck, 20\% em metanol);

- Padrão interno metil tridecanoato (Sigma-Aldrich, pureza $\geq 97,0 \%$ );

- $\quad$ Éter etílico (Synth, pureza $\geq 98,0 \%$ );

- $\quad$ Etanol absoluto (Merck, pureza $\geq 99,9 \%$ );

- Metanol (Lichroslov, pureza 99,9\%);

- $\quad$ Ácido Fosfórico 0,1\% (Fluka);

- $\quad$ Éter de petróleo (Synth, pureza $\geq 95 \%$ );

- $\quad$ Ácido sulfúrico P.A. (Synth, pureza $\geq 95 \%$ );

- $\quad$ Sulfato de sódio anidro P.A. (Synth, pureza $\geq 95 \%$ );

- $\quad$ Sulfato de cobre pentahidratado (Synth, pureza $\geq 95 \%$ );

- $\quad$ Ácido oxálico (Synth, pureza $\geq 95 \%$ );

- $\quad$ Fenolftaleína (Nuclear, pureza $\geq 95 \%$ );

- $\quad$ Zinco em pó (Synth, pureza $\geq 95 \%$ );

- $\quad$ Ácido bórico (Synth, pureza $\geq 95 \%$ ); 
- $\quad$ Azul de metileno (Nuclear, pureza $\geq 95 \%$ );

- Vermelho de metila (Nuclear, pureza $\geq 95 \%$ );

- $\quad$ Ácido clorídrico (Synth, pureza $\geq 95 \%$ ).

\subsubsection{Equipamentos}

- $\quad$ Estufa à vácuo (Tecnal, modelo TE395);

- $\quad$ Bomba de vácuo (Tecnal, modelo TE0581);

- $\quad$ Estufa de convecção forçada (Nova Orgânica, modelo N035/3);

- $\quad$ Agitador mecânico com controle de temperatura (Tecnal, modelo TE139);

- $\quad$ Agitador de tubos (Ika, modelo Labdancer);

- $\quad$ Balança analítica (Adam, modelo A200);

- Balança semi-analítica (AE Adam, modelo PGW 1502i);

- $\quad$ Evaporador rotativo (Tecnal, modelo TE211);

- Centrífuga de bancada (Thermo Electron Corporation, modelo CR3i multifunction);

- Células encamisadas de vidro tipo Pyrex;

- Cromatógrafo líquido de alta eficiência, (UV-VIS detector Shimadzu, modelo SPD-10A);

- Densímetro (Anton Paar, modelo DMA 4500);

- Banho de ultrassom (Unique, modelo USC-1400);

- Banho termostatizado (Tecnal, modelo TE2005);

- $\quad$ Liofilizador de bancada (Terroni, modelo LC 1500).

- Cromatógrafo gasoso com detector de ionização de chama (Shimadzu, modelo GC-2010) e injetor automático (Shimadzu, modelo AOC-20i).

- Rancimat (Metrohm 873 Biodiesel Rancimat); 
- $\quad$ Aparelho extrator tipo Soxhlet (Quimis, M25008);

- Conjunto para determinação de fibra bruta tipo SEBELIN (Marconi);

- $\quad$ Chapa aquecedora (Fisatom, 752A);

- Conjunto de digestão e destilação de Micro-Kjedahl (Tecnal, TE036/1);

- $\quad$ Forno mufla (Edgcon, 3P);

- $\quad$ Analisador de tamanho de partícula por difração a laser (Shimadzu, modelo SALD-201V).

\subsubsection{Diversos}

- Vials para análise de cromatografia líquida de alta eficiência;

- $\quad$ Seringas com agulhas;

- $\quad$ Papel filtro número 1 (Whatman);

- Pinças;

- Funil;

- Vidrarias em geral (balões volumétricos calibrados, béqueres, placas de petri, tubos de polipropileno para centrifugação, cadinhos de vidro, tubos de ensaio, erlenmeyer, bureta).

\subsection{Métodos}

\subsubsection{Origem das folhas de oliva}

As folhas de oliva em pó (Olea europaea) (origem: Espanha) foram adquiridas da empresa Chá e Ciaß Ervas Medicinais, localizada na cidade de Jacareí - SP. A utilização do produto em pó proporcionou o aumento da superfície de contato entre as folhas e o solvente, aumentando a disponibilidade da oleuropeína no processo de extração. 


\subsubsection{Caracterização das folhas de oliva}

\subsubsection{Composição centesimal}

Para a caracterização das folhas de oliva, realizaram-se as análises de composição centesimal, avaliadas de acordo com o teor de cinzas, extrato etéreo (lipídeos), umidade, fibra bruta, determinação de nitrogênio total e proteína bruta, sendo que todas as análises foram realizadas em triplicata, de acordo com os métodos oficiais da Association of Official Analytical Chemists (AOAC), 1980.

\subsection{Teor de Cinzas ou matéria mineral}

Para a análise do teor de cinzas, pesaram-se inicialmente em balança analítica, aproximadamente 2 gramas das folhas de oliva em pó, transferindo-as em seguida para cadinhos devidamente identificados e levando-os para a estufa de convecção forçada à $105^{\circ} \mathrm{C}$ por 12 horas. Após retirar as amostras da estufa, estas foram acondicionadas em um dessecador por 10 minutos, para resfriar sem absorver umidade do ar. Logo após, as amostras foram pesadas, anotando-se a massa correspondente a cada cadinho para posterior cálculo da matéria seca. Em seguida, os cadinhos com as folhas em pó secas foram conduzidos ao forno mufla, à $550^{\circ} \mathrm{C}$ por 4 horas para o cálculo do teor de cinzas.

A Equação 1 abaixo foi utilizada para calcular a porcentagem do teor de cinzas (ou matéria mineral) das folhas de oliva:

$$
\% \text { Cinzas }=\left(\frac{C_{3}-C_{1}}{C_{2}-C_{1}}\right) \times 100
$$

Onde: $C_{1}=$ massa do cadinho vazio; $C_{2}=$ massa do cadinho com amostra antes da secagem; $C_{3}=$ massa do cadinho com amostra depois da secagem. 


\subsection{Extrato etéreo}

Inicialmente, pesaram-se aproximadamente 2 gramas das folhas de oliva em pó em papel de filtro, dobrando-o de uma forma que não houvesse perda de amostra. Em seguida, os papéis de filtro com as folhas devidamente pesadas foram colocados em balões de fundo chato com $200 \mathrm{~mL}$ de éter de petróleo e conduzidos ao extrator Soxhlet para a extração da gordura, até que se alcançasse a temperatura de ebulição do éter, permanecendo no equipamento por um período de 6 a 8 horas. Posteriormente, os balões foram desengordurados externamente com éter sulfúrico, e colocados na estufa de convecção forçada à $105^{\circ} \mathrm{C}$ por um período de 4 horas. Após a retirada dos balões da estufa, os mesmos permaneceram no dessecador por 30 minutos, pesando-se em seguida a massa seca das amostras.

A porcentagem de extrato etéreo das folhas foi determinada segundo a Equação 2 abaixo:

$$
\% \text { Extrato etéreo }=\left(\frac{m b_{f}-m b_{i}}{m}\right) \times 100
$$

Onde: $m b_{i}=$ massa do balão antes da extração; $m b_{f}=$ massa do balão após a extração; $m$ = massa das folhas de oliva em pó.

\subsection{Umidade}

Para esta análise, realizou-se o procedimento para a obtenção da matéria seca descrito no item 4.2.2.1.1.

De acordo com a Equação 3, obtiveram-se os resultados referentes à umidade das folhas de oliva em pó:

$$
\% \text { de Umidade }=\left(\frac{M}{m_{\text {amostra }}}\right) \times 100
$$

Onde: $M$ é a massa perdida durante a secagem $(\mathrm{g})$ e $m_{\text {amostra }}$ é a massa inicial das folhas. 


\subsection{Fibra Bruta}

Para esta análise, pesou-se aproximadamente 1 grama das folhas de oliva em pó previamente secas e desengorduradas, conforme descrito nos itens 4.2.2.1.1 e 4.2.2.1.2, respectivamente, em béqueres devidamente identificados. Em seguida, adicionou-se em cada béquer $100 \mathrm{~mL}$ de ácido sulfúrico $1,25 \%$, levando-os ao aparelho determinador de fibra bruta por 30 minutos, começando a contagem do tempo após a ebulição. Após este tempo, as amostras foram lavadas com água destilada aquecida, retornando o resíduo insolúvel para cada béquer e adicionandose em cada um $200 \mathrm{~mL}$ de hidróxido de sódio 1,25\%, permanecendo no aparelho determinador de fibra bruta por mais 30 minutos, a partir da ebulição. As amostras foram filtradas diretamente em cadinhos de vidro com placa porosa, lavando-se cada um com água destilada aquecida até a obtenção da reação neutra. Em seguida, os cadinhos permaneceram em estufa de convecção forçada a $105^{\circ} \mathrm{C}$ por 4 horas. Após a secagem, as amostras foram transferidas para um dessecador e pesadas após esfriarem. Posteriormente, permaneceram em forno mufla à $550^{\circ} \mathrm{C}$ por mais 4 horas, sendo em seguida transferidas para o dessecador e pesadas novamente.

Os resultados obtidos para a fibra bruta das folhas de oliva em pó foram determinados de acordo com a Equação 4:

$$
\% \text { fibra bruta }=\frac{C_{f}-C_{i}}{M a} \times 100
$$

Onde: $C_{i}=$ massa inicial do cadinho; $C_{f}=$ massa final do cadinho; $M a=$ Massa da amostra

\subsection{Nitrogênio total e proteína bruta pelo método Micro-Kjeldahl}

Inicialmente, pesou-se 1 grama da amostra de folhas de oliva em pó em um papel filtro, transferindo-a em seguida para tubos de ensaio de digestão ( $25 \times 250$ $\mathrm{mm}$ ), adicionando aproximadamente, 1 grama da mistura (97:3) de sulfato de sódio anidro e sulfato de cobre, e em seguida, $3 \mathrm{~mL}$ de ácido sulfúrico concentrado. Feito isso, realizou-se a digestão das amostras nos tubos, em um bloco digestor de MicroKjeldahl na capela, aquecendo lentamente no início, permanecendo no equipamento 
por 2 horas à $400^{\circ} \mathrm{C}$. Após este período, as amostras foram resfriadas, adicionando em cada tubo $35 \mathrm{~mL}$ de água destilada. Utilizando um erlenmeyer de $250 \mathrm{~mL}$, transferiu-se cerca de $10 \mathrm{~mL}$ de ácido bórico $5 \%$ e 2 gotas do indicador misto de vermelho de metila e azul de metileno. $O$ tubo contendo a amostra que sofreu digestão e o erlenmeyer foram posicionadas no aparelho destilador de Micro-Kjeldahl, adicionando $15 \mathrm{~mL}$ de hidróxido de sódio $40 \%$ no tubo com a amostra digerida. Em seguida, realizou-se a destilação, onde foi coletado $65 \mathrm{~mL}$ do destilado, procedendose à titulação do mesmo com a bureta contendo ácido clorídrico a 0,02 N, de fator conhecido. Após este procedimento, realizou-se o cálculo da porcentagem de nitrogênio total na amostra, segundo a Equação 5:

$$
\% N=\frac{V G a x N x F x 14,007 \times 100}{M a}=\% N \times 6,25=\% P B
$$

Onde: $V G a=m L$ gasto de $\mathrm{HCl}$ na amostra; $N=$ normalidade do ácido; $F=$ fator de correção do ácido; $M a=$ massa da amostra $(\mathrm{mg}) ; 14,007=$ Equivalente grama do nitrogênio; $100=$ porcentagem; $6,25=$ corresponde à $\% \mathrm{~N}$ dos alimentos; $P B=$ Proteína bruta.

\subsubsection{Diâmetro médio das partículas}

A determinação do diâmetro médio das partículas (ou análise granulométrica) tem por objetivo calcular o tamanho das mesmas, já que podem ter diferentes formas que podem influenciar em algumas propriedades, como fluidez e interação com fluidos (LIMA e da LUZ, 2001). O diâmetro médio das partículas geralmente é feito por peneiramento ou peneiramento e sedimentação.

Esta análise foi realizada em triplicata, onde foram pesadas cerca de 150 gramas de folhas de oliva em pó, as quais foram submetidas em peneiras Tyler com meshs de 10, 14, 20, 28 e 48 com aberturas de malhas de 1,70; 1,18; 0,850; 0,600; 0,425 e 0,300 ( $\mathrm{mm})$, previamente limpas, secas e pesadas vazias individualmente, além de um peneiro (chamado também de fundo), que consiste em um suporte de aço inox cilíndrico onde ficam sedimentados a maior parte dos sólidos que passam pelas peneiras. Em seguida, as mesmas foram conduzidas ao agitador de peneiras (Bertel 
Ltda, Maq: 1669, Série 0401, tipo: magnético) (Figura 7) por 10 minutos e após este tempo, foram pesadas individualmente em balança analítica (Ohaus Adventurer ${ }^{\mathrm{TM}}$, ARC120) para a determinação da porcentagem média de sólidos sedimentados em cada diâmetro.

Após a análise utilizando-se as peneiras, a fração do fundo foi submetida ao equipamento por difração a laser para averiguar o tamanho médio das partículas das folhas de oliva em pó com diâmetros entre 0,25 e $350 \mu \mathrm{m}$.

O diâmetro médio das partículas $\left(d m_{p}\right)$ foi determinado segundo o método da ASAE Standarts (ASAE, 1998), através da Equação 6:

$$
d m_{p}=\exp \left\{\frac{\sum_{i=1}^{n}\left[w_{i} \log \left(d_{i} \times d_{i+1}\right)^{0,5}\right]}{\sum_{i=1}^{n} w_{i}}\right\}
$$

Onde: $d_{i}$ é a abertura nominal da i-ésima peneira $(\mathrm{mm})$; $d_{i+1}$ é a abertura nominal da peneira $(i+1)(\mathrm{mm})$ e $w_{i}$ é a massa da amostra retida na i-ésima peneira. 
Figura 7: Agitador de peneiras utilizado para a análise do diâmetro médio das partículas das folhas de oliva em pó.

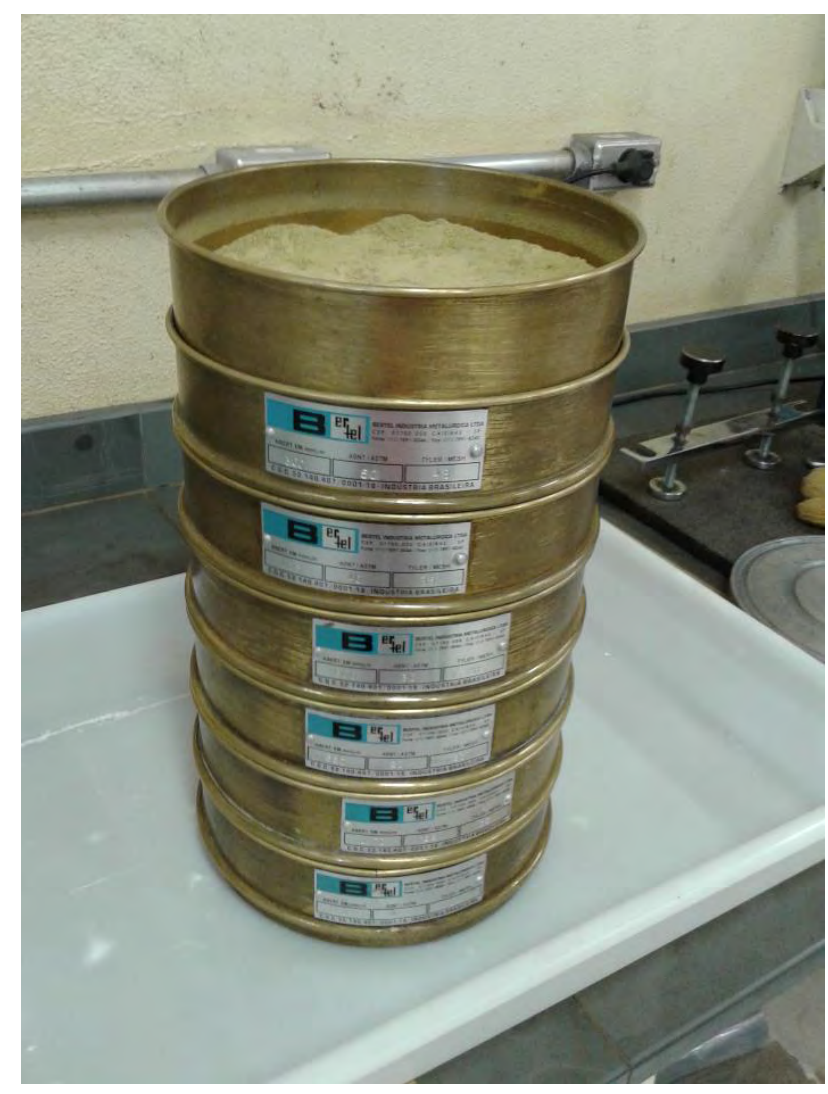

Fonte: Própria autoria.

\subsubsection{Densidade real}

A determinação da densidade real das folhas de oliva em pó foi realizada pela Central Analítica do Instituto de Química da Unicamp, por meio de picnometria de gás hélio, em picnômetro automático Quantachrome Ultrapyc 1200e. De acordo com o Instruction Manual Multivolume Pycnometer Micromeritics (1987), a picnometria de gás hélio permite obter o volume de um sólido pela redução do fluxo de gás em uma câmara de medida que é causada pela presença de um sólido.

\subsubsection{Densidade aparente}

A determinação da densidade aparente das folhas de oliva foi realizada em triplicata, pesando-se a massa de folhas em pó em um recipiente de volume 
conhecido, calibrado com água. Em seguida, fez-se o cálculo da densidade aparente utilizando a Equação 7 (Scharlack, 2015) abaixo:

$$
\rho_{a}=\frac{m_{\text {amostra }}}{\text { Vol }_{\text {total }}}
$$

Onde: $\rho_{a}=$ densidade aparente das folhas $\left(\mathrm{g} / \mathrm{cm}^{3}\right) ; m_{\text {amostra }}=$ massa das folhas $(\mathrm{g})$; vol total $_{\text {= }}$ volume total de água $\left(\mathrm{cm}^{3}\right)$.

\subsubsection{Porosidade do leito}

A porosidade total das folhas de oliva em pó adquiridas da empresa Chá e Cia® foi calculada através da Equação 8 (Scharlack, 2015) abaixo:

$$
\varepsilon=\left(1-\frac{\rho_{a}}{\rho_{r}}\right)
$$

Onde: $\varepsilon=$ porosidade do leito; $\rho_{a}=$ densidade aparente das folhas $\left(\mathrm{g} / \mathrm{cm}^{3}\right) ; \rho_{r}=$ densidade real das folhas $\left(\mathrm{g} / \mathrm{cm}^{3}\right)$.

As análises para a obtenção dos resultados de densidade real e aparente foram determinadas conforme já descritos nos itens 4.2.2.3 e 4.2.2.4, respectivamente.

\subsubsection{Teor de oleuropeína nas folhas de oliva}

Para a análise da quantificação de oleuropeína nas folhas de oliva em pó em Cromatografia Líquida de Alta Eficiência (HPLC), foi utilizada a metodologia descrita por Altinyay e Altun (2006). Em uma balança analítica, pesaram-se cerca de 5 gramas das folhas de oliva em pó, as quais foram misturadas com $50 \mathrm{~mL}$ de metanol (Lichroslov, pureza 99,9\%) com o auxílio de um agitador magnético por um período de 2 horas, à temperatura ambiente $\left(25^{\circ} \mathrm{C}\right)$. Após esse período, o sistema foi filtrado e evaporado em estufa à vácuo à uma temperatura que não excedesse $40^{\circ} \mathrm{C}$, à 
pressão de $600 \mathrm{mmHg}$. Em seguida, as amostras, já secas, foram então dissolvidas em $50 \mathrm{~mL}$ de metanol (grau HPLC) e as soluções filtradas em seringas contendo filtros de 0,45 $\mathrm{mm}$. Para verificar se o resíduo sólido remanescente do procedimento de extração ainda continha oleuropeína, este foi submetido a um novo contato com o solvente metanol, repetindo-se todas as etapas subsequentes. Este procedimento foi repetido 4 vezes, até o esgotamento da oleuropeína nas folhas.

Para a quantificação da oleuropeína, foi utilizado um cromatógrafo da marca Shimadzu, modelo SPD-10A, contendo detector UV $280 \mathrm{~nm}$ com fluxo de 1,0 $\mathrm{mL} /$ minuto e pressão de 265 kgf, aproximadamente, coluna Shimadzu CLC-ODS 25 cm, controlador Shimadzu SCL-10AVP e mostrador automático SIL-10AF e com volume de injeção de $20 \mu \mathrm{l}$. A fase móvel foi composta de água + ácido fosfórico 0,1\%, metanol (Lichroslov, pureza 99,9\%). A curva de calibração foi construída utilizando-se oleuropeína padrão (pureza: >80\%), adquirida da Sigma-Aldrich (Saint Louis, MO) e o programa LabSolutions (Version 5.57, 2008-2013, Shimadzu Corporation). Para a soma do teor de oleuropeína em todas os extratos provenientes da extração sequencial com metanol foi considerado o teor total de oleuropeína nas folhas em pó.

Esta análise foi realizada nas dependências do Laboratório de Microbiologia e Micotoxicologia de Alimentos, no Departamento de Engenharia de Alimentos, da Faculdade de Zootecnia e Engenharia de Alimentos da Universidade de São Paulo, sob supervisão do professor Dr. Carlos Augusto Fernandes de Oliveira.

\subsubsection{Experimentos para a obtenção dos extratos de folhas de oliva}

Para os experimentos de obtenção dos extratos de folhas de oliva, foi utilizado como solvente uma mistura de etanol e água na proporção 70:30, em massa. Essa proporção foi otimizada em um trabalho prévio desenvolvido no Laboratório de Engenharia de Separações (LES) (PACETTA, 2013). Pacetta (2013) também sugeriu o uso de aproximadamente $1 \%$ de ácido acético na mistura, a fim de se estabilizar a molécula de oleuropeína. O solvente hidroalcoólico foi preparado através da mistura de quantidades conhecidas de etanol absoluto (Merck, Darmstadt, Alemanha, pureza $\geq 99,9 \%$ ) e água destilada. A porcentagem de água no solvente foi checada em um 
densímetro digital de bancada (Anton Paar, modelo DMA 4500), ao longo de todo o período experimental.

Foram realizados quatro diferentes procedimentos para a realização das extrações. Nos procedimentos tipo I e tipo II, foram estudadas a influência da variação da temperatura sob a extração da oleuropeína com o auxílio de agitação mecânica por maceração (procedimento tipo I) e de ultrassom (procedimento tipo II). Após a avaliação dos resultados provenientes desses dois primeiros procedimentos, decidiuse pela realização do procedimento tipo III, no qual a temperatura foi mantida fixa e variou-se a proporção folhas:solvente. Neste procedimento tipo III, os experimentos foram realizados somente por maceração com e sem a presença do ácido acético, para fins de comparação. Por fim, foi realizado um procedimento tipo IV, que consistiu numa extração sequencial por maceração para verificar o número de etapas que seriam necessárias para o esgotamento da oleuropeína na matéria-prima.

Os resultados foram expressos em termos de rendimento de oleuropeína (RO) (Equação 9), teor de oleuropeína nos extratos (TO) (obtido através da análise em HPLC) e rendimento global de extrato (RG) (Equação 10).

$$
\begin{gathered}
R O(\%)=\frac{\text { massa de oleuropeína no extrato }}{\text { massa de oleuropeína na matéria }- \text { prima }} \\
R G(\%)=\frac{\text { massa de extrato }}{\text { massa de matéria }- \text { prima }}
\end{gathered}
$$

Todos os experimentos foram realizados em triplicata e a descrição detalhada dos quatro tipos de procedimentos está apresentada a seguir:

\section{Procedimento tipo I: Maceração (agitação magnética)}

Com 0 auxílio de béqueres, foram pesados (em balança analítica) aproximadamente 10 gramas de folhas de oliva em pó, 30 gramas de etanol contendo $30 \%$ de água (proporcionando uma proporção folhas:solvente igual a 1:3) e 0,40 gramas de ácido acético P.A. (Synth). Após as pesagens, as massas foram inseridas em recipientes de vidro encamisados e conectadas a um banho termostático, onde 
ficaram sob agitação magnética por 2 horas (Figura 8). Cada triplicata foi realizada em diferentes temperaturas $\left(20,30,40,50\right.$ e $\left.60^{\circ} \mathrm{C}\right)$ com o objetivo de avaliar a influência da temperatura na extração da oleuropeína. Após o período de extração, as amostras foram filtradas em papel filtro $\mathrm{n}^{\circ} 1$ (Whatman) e transferidas para um balão de $250 \mathrm{~mL}$ para a evaporação do etanol no evaporador rotativo (Figura 9), à $40^{\circ} \mathrm{C}$. Após a evaporação do etanol, adicionaram-se aproximadamente $20 \mathrm{~mL}$ de água deionizada ao balão para desprendimento da massa retida após a secagem, sendo esta transferida para béqueres de $50 \mathrm{~mL}$, congeladas e liofilizadas (remoção da água) para a obtenção do extrato seco.

Figura 8: Extração da oleuropeína utilizando o agitador magnético.

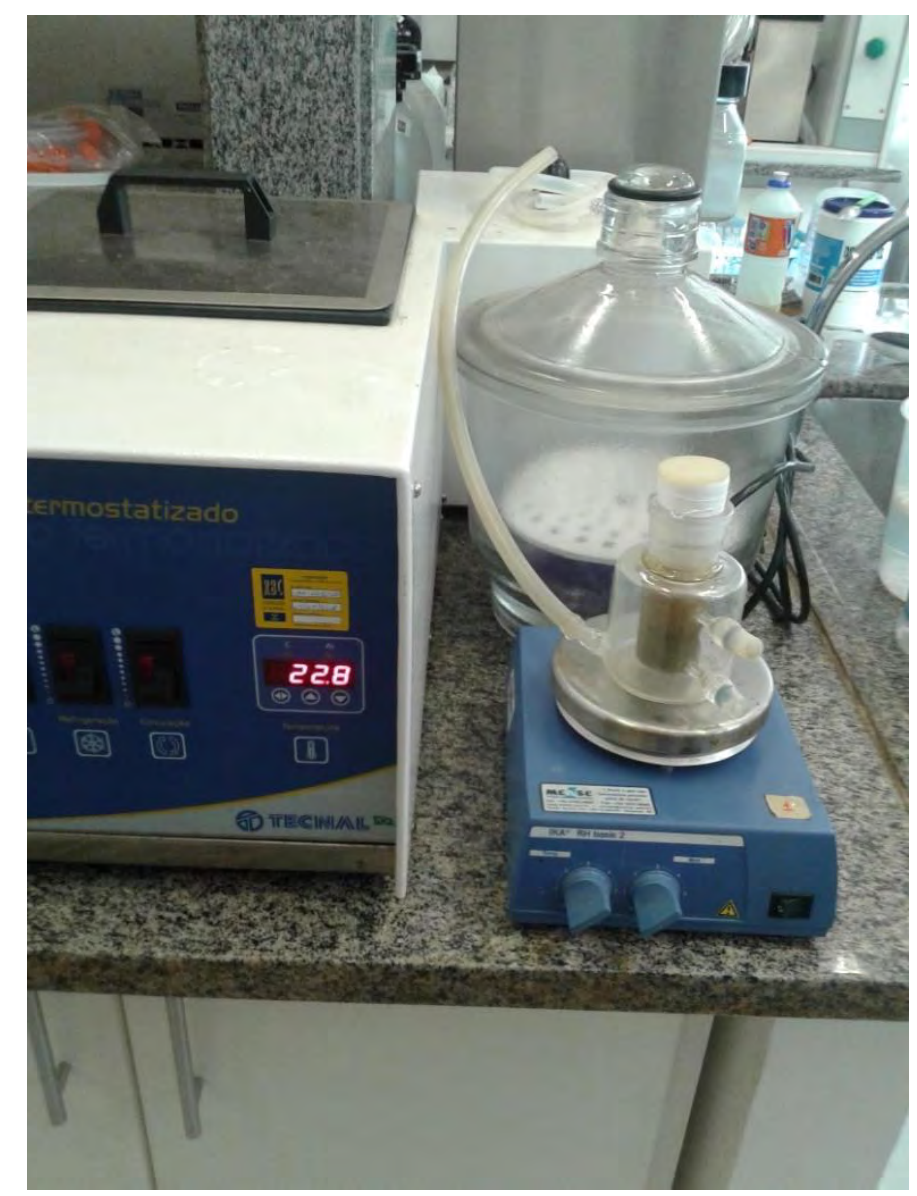

Fonte: Própria autoria. 
Figura 9: Secagem do etanol em evaporador rotativo.

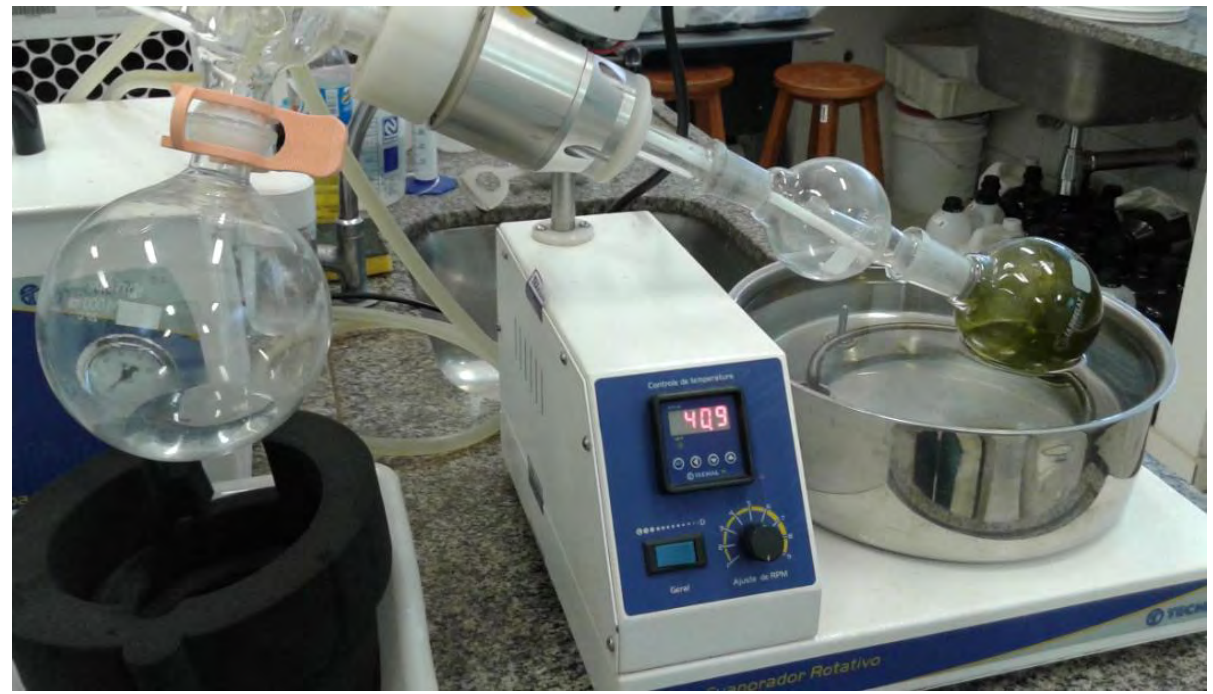

Fonte: Própria autoria.

\section{Procedimento tipo II: Ultrassom}

Este procedimento foi executado utilizando-se as mesmas temperaturas utilizadas no procedimento tipo I $\left(20,30,40,50\right.$ e $\left.60^{\circ} \mathrm{C}\right)$, porém, os recipientes de vidro encamisados foram alocados dentro de um banho de ultrassom conectado a um banho termostatizado. Todas as etapas subsequentes foram as mesmas já descritas no procedimento tipo I.

Figura 10: Extração da oleuropeína utilizando o banho de ultrassom.

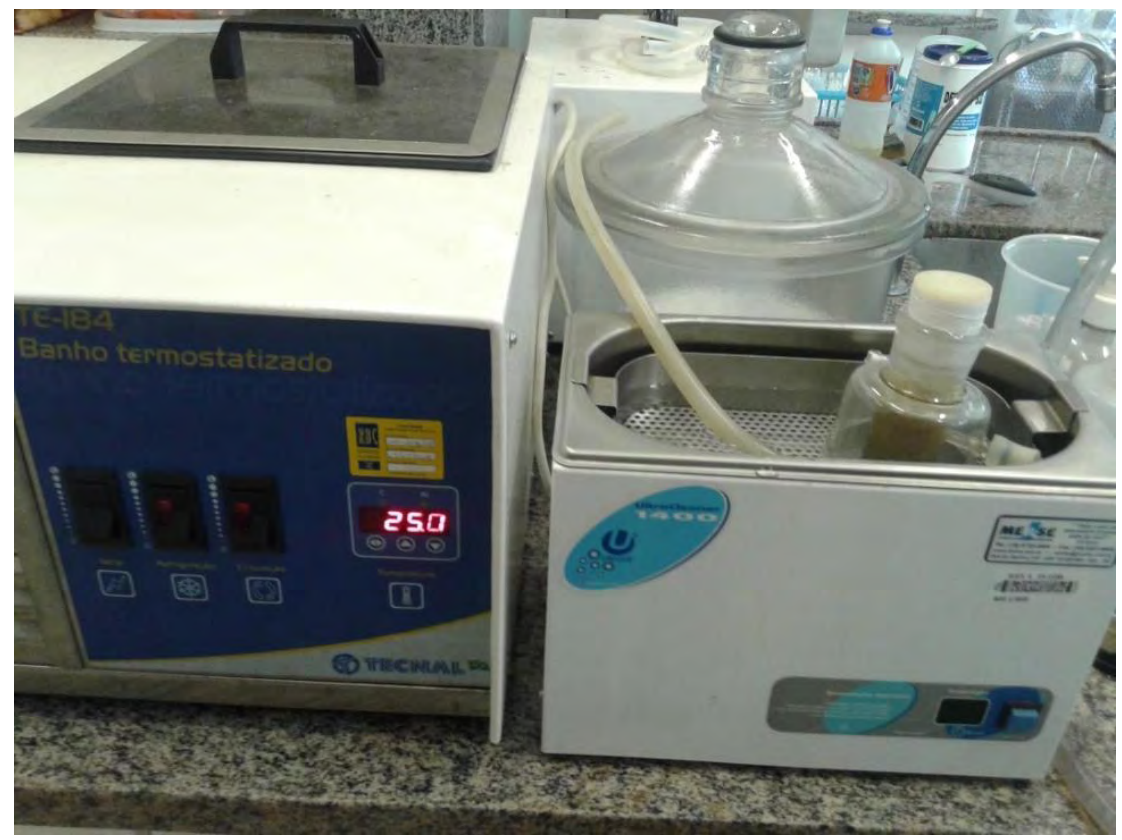

Fonte: Própria autoria. 


\section{Procedimento tipo III: Agitação magnética à temperatura ambiente e evaporação do solvente em estufa à vácuo com ou sem a adição de ácido acético}

Os experimentos do procedimento tipo III foram realizados à temperatura ambiente $\left(25{ }^{\circ} \mathrm{C}\right)$ e sob agitação magnética, variando-se as proporções folhas:solvente nos seguintes valores: 1:3 (10 g de folhas de oliva em pó + $30 \mathrm{~g}$ de solvente hidroalcoólico), 1:6 (5 g de folhas de oliva em pó + $30 \mathrm{~g}$ de solvente hidroalcoólico) e 1:8 (5 g de folhas de oliva em pó + $40 \mathrm{~g}$ de solvente hidroalcoólico). Cada proporção foi estudada em triplicata, com e sem a adição do ácido acético. Assim como no procedimento tipo I, as extrações foram realizadas no interior de recipientes de vidro encamisados, que permaneceram sob agitação magnética por 2 horas. Após o período de extração, as amostras foram filtradas em papel filtro nำ1 (Whatman), sendo o extrato alcoólico colocado em um béquer de $50 \mathrm{~mL}$ e conduzido à uma estufa à vácuo à $40^{\circ} \mathrm{C}$ e $600 \mathrm{mmHg}$ para a evaporação do etanol até peso constante. Após a evaporação, foram adicionados $20 \mathrm{~mL}$ de água deionizada aos béqueres, seguindo para o congelamento e liofilização (remoção da água), para a obtenção do extrato seco.

\section{Procedimento tipo IV: Extração sequencial}

Os experimentos do procedimento tipo IV foram realizados também à temperatura ambiente $\left(25^{\circ} \mathrm{C}\right)$, sob agitação magnética, utilizando-se a proporção de massa de folha:etanol 1:3 (10 g de folhas de oliva em pó + $30 \mathrm{~g}$ de solvente hidroalcoólico) e a adição de $1 \%$ de ácido acético P.A. O procedimento realizado foi o mesmo descrito para o procedimento tipo III. A diferença para este experimento de extração é a de que após a filtragem das amostras, os filtros contendo as massas das folhas de oliva foram conduzidos à uma estufa de convecção forçada, à temperatura de $60^{\circ} \mathrm{C}$ para a evaporação do etanol, pois neste procedimento as massas secas das folhas seriam utilizadas novamente para uma nova extração, seguindo-se o mesmo procedimento descrito para a primeira, a qual foi repetida 4 vezes (em duplicata), à fim de analisar posteriormente o teor de oleuropeína que ainda permanece nas folhas após várias extrações sequenciadas. 


\subsubsection{Análise do teor de oleuropeína nos extratos}

Após a obtenção dos extratos liofilizados das folhas de oliva, os mesmos foram preparados para a posterior quantificação em cromatógrafo líquido (HPLC). Em uma balança analítica pesaram-se aproximadamente 0,040 gramas de extrato liofilizado em tubos de centrífuga de $15 \mathrm{~mL}$. Em seguida, adicionou-se à cada tubo $1 \mathrm{~mL}$ da mistura de metanol grau HPLC e água deionizada, na razão 1:1, permanecendo sob agitação por 36 minutos no banho de ultrassom. Após a agitação, os tubos foram conduzidos à centrífuga, à $25^{\circ} \mathrm{C}$ por 10 minutos, com rotação de $4500 \mathrm{rpm}$. O sobrenadante foi coletado e filtrado em seringas com filtros de $0,45 \mathrm{~mm}$, e transferido para frascos (tipo vials) devidamente identificados para posterior análise em cromatógrafo líquido de alta eficiência (HPLC). A quantificação de oleuropeína na alíquota filtrada foi realizada utilizando-se o mesmo procedimento já descrito no item 4.2.2.6.

\subsubsection{Estudo da aplicação dos extratos de oleuropeína em óleos vegetais}

Dentre os extratos obtidos em todos os experimentos descritos anteriormente, o que continha o maior teor de oleuropeína foi selecionado para o estudo da aplicação do produto em óleos vegetais, com o objetivo de verificar a influência do mesmo sobre o aumento da estabilidade oxidativa dos óleos. Os óleos selecionados para este estudo foram os azeites de oliva comum e extra-virgem (ambos da marca Gallo), e os óleos de girassol bruto (Caramuru) e refinado (Liza). Os óleos de girassol foram os mesmos utilizados por Scharlack (2015), que estudou a influência dos teores de ácidos clorogênicos e tocoferóis presentes nestes óleos sobre sua estabilidade oxidativa. 


\subsubsection{Caracterização dos óleos vegetais utilizados no estudo}

\subsection{Composição em ácidos graxos}

As composições em ácidos graxos das amostras dos azeites extra-virgem e comum foram determinadas por meio de cromatografia gasosa de ésteres metílicos de ácidos graxos, em relação aos métodos oficiais Ce 1-62 e Ce 2-66 da AOCS (1998), utilizando metil tridecanoato como padrão interno (ZENEBON, et al., 2008). As composições em ácidos graxos dos óleos de girassol bruto e refinado foram determinadas por Scharlack (2015) seguindo esta mesma metodologia.

Para a inserção das amostras no cromatógrafo gasoso e posterior obtenção dos dados de composição dos ácidos graxos foi necessário a esterificação prévia dos óleos vegetais. Inicialmente, preparou-se alguns reagentes que seriam utilizados para a análise, como o reagente de saponificação $(\mathrm{KOH}$ ou $\mathrm{NaOH} 0,5 \mathrm{M}$ em metanol anidro, cerca de 2,0 gramas de $\mathrm{NaOH}$ em $100 \mathrm{~mL}$ ) e o reagente de esterificação (complexo de trifluoreto de boro-metanol ou $\mathrm{BF}_{3}$, Merck).

As amostras foram preparadas da seguinte maneira: pesaram-se cerca de 50 $\mathrm{mg}$ dos óleos em um tubo de centrífuga de $50 \mathrm{~mL}$ e, em seguida, adicionaram-se 4 $\mathrm{mL}$ do reagente de saponificação ( $\mathrm{NaOH}$ 0,5 M em metanol), tampando-o e agitando$\mathrm{o}$, e colocando-o em um béquer contendo água fervente por 3 a 5 minutos. Após este tempo, adiciononaram-se $5 \mathrm{~mL}$ do reagente de esterificação $\left(\mathrm{BF}_{3}\right)$, mantendo o tubo sob aquecimento e agitação durante 5 minutos, e resfriando-o em seguida em água corrente. Em seguida, adicionaram-se ao tubo $4 \mathrm{~mL}$ da solução salina saturada de $\mathrm{NaCl}$ em água, agitando-o e adicionando-se $5 \mathrm{~mL}$ de hexano (grau cromatográfico), seguido de nova agitação por 30 segundos, e por fim, deixando-o em repouso até se completar a separação de fases. Transferiu-se então a fase superior, que é a fase que contém os ésteres graxos dissolvidos no hexano, para um frasco de penicilina identificado, utilizando para a transferência uma pipeta de Pasteur. Em seguida, tampou-se o frasco, lacrando-o com parafilme, deixando-o no freezer até o momento da inserção.

Para a determinação da composição em ácidos graxos foi utilizado um cromatógrafo gasoso Shimadzu 2010 AF (Japão), injetor automático Shimadzu, modelo AOC 20i e como detector de ionização de chama foram utilizadas as seguintes condições: coluna capilar altamente polar de bis-ciano propil polisiloxano $0,20 \mu \mathrm{m}, 100$ 
m x 0,25 mm de diâmetro interno (SP - 2560, Supelco, EUA), gás hélio, como gás de arraste (velocidade linear de $19,5 \mathrm{~cm} / \mathrm{seg}$ ), temperatura da coluna de $140^{\circ} \mathrm{C}$ durante 5 minutos, de 140 à $240^{\circ} \mathrm{C}$ a uma taxa de $4^{\circ} \mathrm{C} / \mathrm{min}, 240^{\circ} \mathrm{C}$ por 15 minutos, temperatura do injetor de $250^{\circ} \mathrm{C}$, temperatura do detector de $260^{\circ} \mathrm{C}$ e $1,0 \mu \mathrm{L}$ de volume de injeção, taxa de Split 100:1.

Para a identificação dos ácidos graxos das amostras realizou-se a comparação com padrões externos adquiridos da Supelco (EUA) e a quantificação das mesmas foi realizada através da conversão das porcentagens das áreas dos picos, em porcentagem de massa, utilizando os fatores de correção de resposta do detector de ionização de chama e de conversão de ésteres metílicos de ácidos graxos. A Equação 11 foi empregada para o cálculo da composição de cada ácido graxo (AG):

$$
\% A G=\frac{S P A G}{\sum S P A G} \times 100
$$

Onde: $S P A G=$ área de cada pico de ácido graxo; $\Sigma S P A G=$ somatória de todas as áreas dos picos de ácidos graxos.

\subsection{Acidez livre}

A análise da acidez livre foi realizada em 4 tipos de óleos: azeite de oliva extravirgem e comum (Gallo), óleo de girassol refinado (Liza) e óleo de girassol bruto (Caramuru).

A determinação do índice de acidez livre por titulação foi realizada segundo os métodos descritos pela IUPAC 2201 (1979). O procedimento foi realizado experimentalmente em triplicata, da seguinte maneira: pesou-se aproximadamente 1 grama de óleo de cada amostra, em um béquer de $250 \mathrm{~mL}$. Adicionaram-se $60 \mathrm{~mL}$ de solução éter etílico:etanol $(1: 1 \mathrm{v} / \mathrm{v})$ e, em seguida, duas gotas do indicador fenolftaleína. As amostras foram tituladas com solução de hidróxido de sódio 0,01 N até o aparecimento da coloração rósea persistindo por 30 segundos, indicando que a 
solução titulada estaria neutra. Anotou-se o volume gasto de hidróxido de sódio de cada amostra para posterior cálculo da acidez, em porcentagem de ácido oléico.

O cálculo do índice de acidez das amostras foi realizado de acordo com a Equação 12:

$$
\% \text { Acidez em ácido oléico }=\frac{V \times f \times 282,4614}{\operatorname{ma} \times 10}
$$

Onde: $V=$ volume gasto do hidróxido de sódio; $f=$ normalidade da solução de $\mathrm{NaOH}$, devidamente padronizada; $m a$ = massa da amostra de óleo; 282,4614 = massa molar do ácido oléico.

\subsubsection{Determinação da estabilidade oxidativa}

As análises de estabilidade oxidativa foram realizadas nos 4 tipos de óleos supramencionados: azeite de oliva extra-virgem e comum (Gallo), óleo de girassol refinado (Liza) e óleo de girassol bruto (Caramuru).

Para a realização da análise de estabilidade oxidativa, pesaram-se inicialmente em um tubo de centrífuga de $50 \mathrm{~mL}$, aproximadamente 3 gramas de óleo, juntamente com 0,0015 gramas do extrato liofilizado (valor baseado segundo a metodologia descrita por Jimenez et al. (2011)), contendo cerca de $19 \mathrm{~g} / 100 \mathrm{~g}$ de oleuropeína. Para uma melhor solubilização do óleo com o extrato, os tubos permaneceram sob agitação em um agitador de tubos (Ika) por 1 hora e, em seguida, foram envoltos em papel alumínio e acondicionados ao abrigo da luz e do oxigênio até a data da análise. As amostras de óleos com os extratos foram preparadas cerca de 4 dias antes da análise para que se tivesse o maior tempo de contato possível entre óleo e extrato. Foram realizadas também análises da estabilidade oxidativa dos óleos adicionando-se o dobro do extrato de folhas de oliva nas amostras, cerca de 0,0030 gramas, utilizandose o mesmo procedimento descrito acima, a fim de verificar a influência da concentração de oleuropeína sobre a estabilidade oxidativa dos óleos vegetais.

Os experimentos também foram executados sem a adição dos extratos, a fim de comparar o tempo de indução com as amostras de óleos adicionadas de extrato, verificando assim se a oleuropeína realizou ou não a atividade antioxidante, 
aumentando a estabilidade oxidativa dos mesmos. Cada sistema, com ou sem extrato, foi preparado em duplicata.

As análises de estabilidade oxidativa foram realizadas no aparelho Metrohm 873 Biodiesel Rancimat (Figura 11), pré-aquecido a $110^{\circ} \mathrm{C}$ com fluxo de gás $20 \mathrm{~L} / \mathrm{h}$, no Laboratório Multiusuário de Análise de Alimentos, da Faculdade de Zootecnia e Engenharia de Alimentos, da Universidade de São Paulo. As análises foram realizadas em duplicata e os resultados dos tempos de indução foram expressos em horas.

A determinação da estabilidade oxidativa baseada no aumento da condutividade elétrica foi originalmente desenvolvida por Hadorn e Zurcher (1974), utilizando o equipamento denominado Rancimat 617. Neste aparelho, o fluxo de ar passa através do óleo (mantido sob aquecimento em temperatura que varia de $100 \mathrm{a}$ $140^{\circ} \mathrm{C}$ ), depois borbulha em água deionizada, arrastando os ácidos carboxílicos voláteis (principalmente o ácido fórmico), gerados do processo de oxidação, que se solubilizam, aumentando a condutividade elétrica da água (JORGE, 2010).

Figura 11: Equipamento Rancimat.

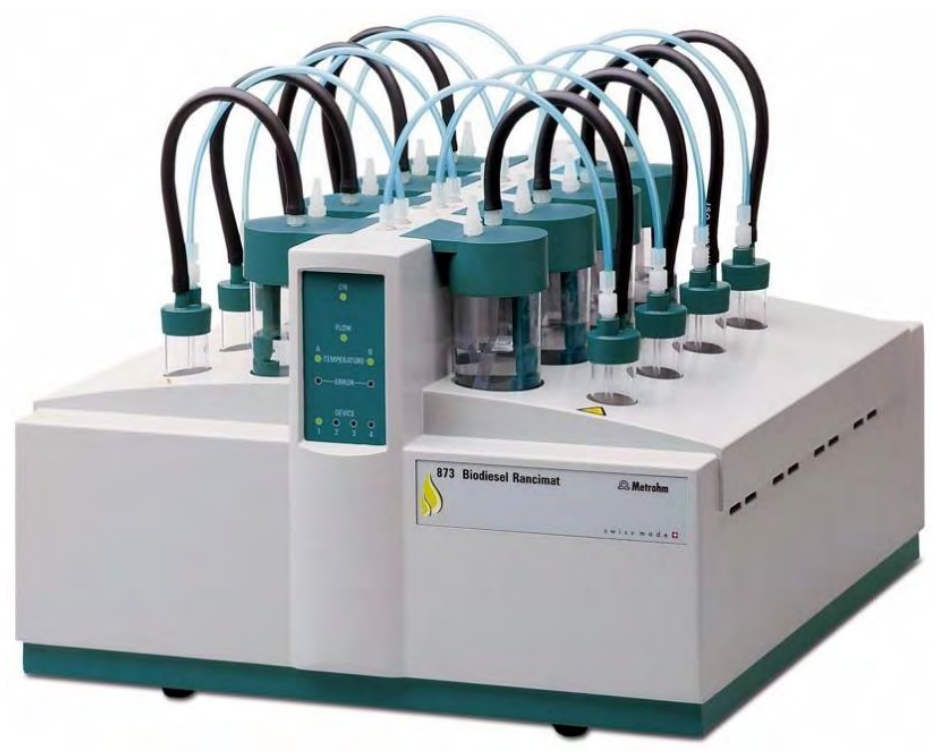

Fonte: Disponível em:<http://www.balkananalytical.com>. Acesso em: 21 fev. 2016. 


\subsubsection{Análise estatística}

Todos os resultados obtidos através dos experimentos de extração de oleuropeína, bem como os de estabilidade oxidativa em óleos vegetais, foram avaliados estatisticamente utilizando o Teste de Duncan a nível de confiança de 95\%, através do programa SAS® (Versão 9.3, SAS Institute Inc., EUA). 


\section{Resultados e discussão}

\subsection{Caracterização das folhas de oliva}

As folhas de oliva em pó (Chá e Cia) foram caracterizadas em relação à sua composição centesimal, densidade real, densidade aparente, porosidade, diâmetro médio das partículas e teor de oleuropeína.

\subsubsection{Composição centesimal}

A Tabela 1 apresenta os resultados encontrados para as análises de composição centesimal nas folhas de oliva em pó, como descrito no item 4.2.2.1. Esses resultados também foram comparados com os obtidos por Erbay e Icier (2009) para folhas frescas e por Pacetta (2013) para folhas secas.

Tabela 1: Resultados das análises de composição centesimal das folhas de oliva em pó.

\begin{tabular}{ccc}
\hline Análises & Resultados (\%) & Literatura (\%) \\
\hline Umidade & $4,82 \pm 0,06$ & $49,83^{1} ; 8,3^{2}$ \\
Cinzas $^{*}$ & $11,89 \pm 0,02$ & $3,61^{1} ; 5,8^{2}$ \\
Fibra bruta $^{*}$ & $14,6 \pm 0,3$ & $13,95^{1}$ \\
Extrato etéreo* $^{*}$ & $3,7 \pm 0,1$ & $13,03^{1}$ \\
Proteína $^{*}$ & $10,9 \pm 0,1$ & $10,86^{1}$ \\
Carboidratos $^{* *}$ & 59,00 & $54,96^{1}$ \\
\hline ase seca; ${ }^{* *}$ obtido por diferença (em base seca); ${ }^{1}$ Erbay e Icier (2009); ${ }^{2}$ Pacetta (2013).
\end{tabular}

*em base seca; ${ }^{* *}$ obtido por diferença (em base seca); ${ }^{1}$ Erbay e Icier (2009); ${ }^{2}$ Pacetta (2013). Fonte: Própria autoria.

Como neste trabalho foram utilizadas folhas de oliva em pó já secas, os valores de teor de cinzas, fibra bruta, extrato etéreo, proteína e carboidratos, na Tabela 1, estão representados em base seca, a fim de se fazer uma comparação adequada com os dados da literatura. Erbay e Icier (2009) realizaram a composição centesimal em folhas de oliveira colhidas em árvores cultivadas no campus da Universidade Ege, na Turquia. Os resultados encontrados pelos autores mostraram que os teores de fibra 
bruta, proteína e carboidratos são muito semelhantes aos das amostras utilizadas no presente trabalho. Porém, os teores de cinzas e de lipídeos (extrato etéreo) foram bem diferentes. Pacetta (2013) determinou teores de cinzas e umidade de folhas de oliveira em pó cultivadas em Estiva Gerbi, no interior de São Paulo. Em comparação aos dados obtidos neste trabalho, este autor obteve quase o dobro do teor de umidade $\mathrm{e}$ metade do teor de cinzas.

\subsubsection{Diâmetro médio das partículas, densidade aparente, densidade real e porosidade}

$\mathrm{Na}$ Tabela 2 a seguir estão apresentados os resultados da análise do diâmetro médio das partículas, descrita no item 4.2.3:

Tabela 2: Quantidade de folhas de oliva em pó retida em cada uma das peneiras.

\begin{tabular}{cccc}
\hline Mesh/Tyler & Quantidade (\%) & $\mathbf{d}_{\mathbf{i}}(\mathbf{m m})$ & $\left(\mathbf{d}_{\mathbf{i}+1}\right)(\mathbf{m m})$ \\
\hline 10 & $0,41 \pm 0,03$ & 1,7 & 2,0000 \\
14 & $0,46 \pm 0,31$ & 1,18 & 1,4000 \\
20 & $0,39 \pm 0,20$ & 0,850 & 1,0000 \\
28 & $0,37 \pm 0,04$ & 0,600 & 0,7100 \\
35 & $0,21 \pm 0,09$ & 0,425 & 0,5000 \\
48 & $2,38 \pm 2,66$ & 0,300 & 0,3550 \\
65 (Fundo) & $94,47 \pm 2,62$ & 0,212 & \\
\hline
\end{tabular}

Fonte: Própria autoria.

O diâmetro médio das partículas $\left(d m_{p}\right)$ das folhas de oliva foi calculado conforme a Equação 6, obtendo-se um $d m_{p}$ no valor de $0,71 \mathrm{~mm}$. A partir destes dados foi possível a avaliação do tamanho e das dimensões das partículas das folhas, além do conhecimento da distribuição granulométrica do material vegetal quando submetido à um leito fixo. Porém, verificou-se que uma grande porcentagem das folhas de oliva em pó ficou concentrada no fundo da peneira. Para a avaliação da granulometria do material concentrado nessa fração, realizou-se a análise para a determinação do tamanho médio das partículas $(0,25$ à $350 \mu \mathrm{m})$, realizada no 
equipamento por difração a laser, disponível no Laboratório de Processos de Engenharia de Alimentos (FZEA - USP). Os resultados dessa análise estão apresentados na Figura 12:

Figura 12: Distribuição granulométrica das folhas de oliva em pó por difração a laser.

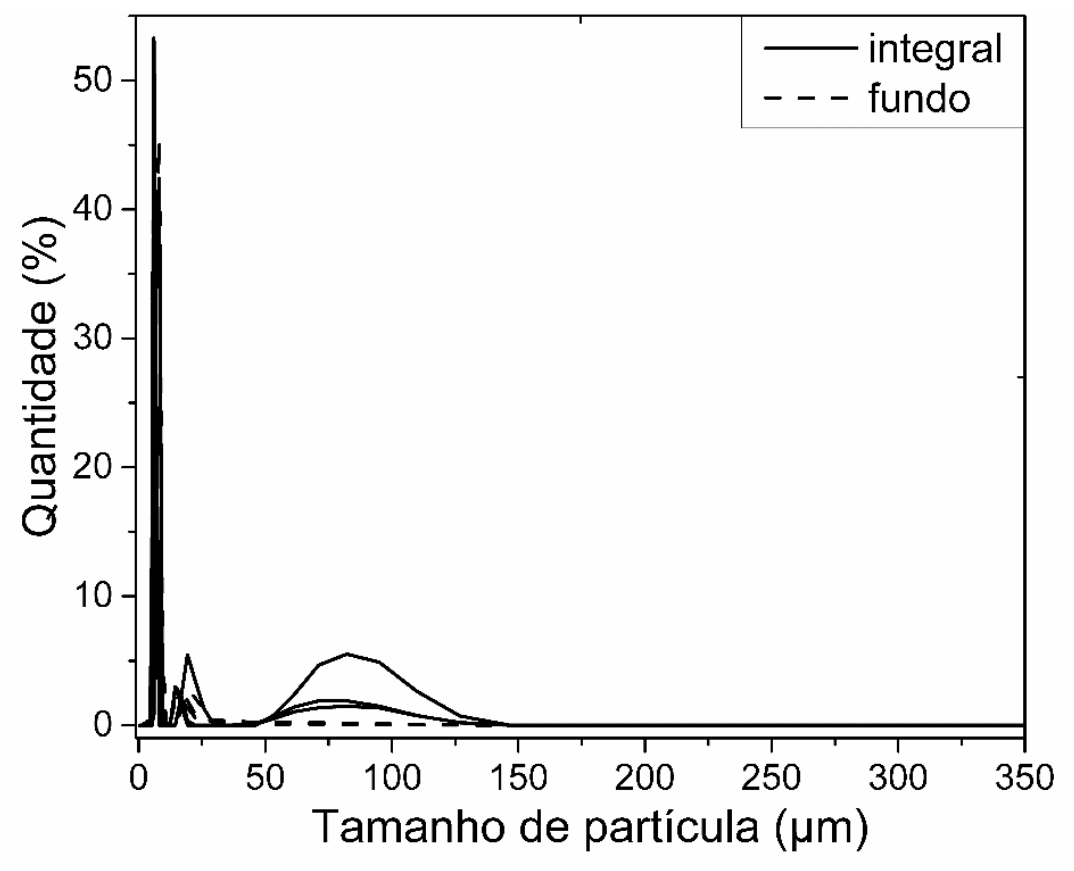

Fonte: Própria autoria.

À partir da Figura 12, verifica-se que as folhas de oliva em pó apresentam um tamanho médio de 40 à $150 \mu \mathrm{m}$ dentro da faixa limite de detecção do equipamento, de acordo com este método. Pode-se verificar que como a maior parte das folhas ficaram concentradas no fundo da peneira, e segundo a análise realizada no equipamento por difração a laser, confirmou-se que o material vegetal apresenta tamanhos de partícula muito próximos, ocasionando em diâmetros similares quando comparou-se a fração do fundo e a integral, como mostra a Figura 12.

$\mathrm{Na}$ Tabela 3, estão apresentados os dados de densidade real (descrita no item 4.2.2.3), densidade aparente (item 4.2.2.4) e porosidade (item 4.2.2.5), sendo todos os valores obtidos através dos cálculos das Equações 7 e 8 para densidade aparente e porosidade, respectivamente. 
Tabela 3: Resultados dos valores médios de densidade real, densidade aparente e porosidade do leito das folhas de oliva em pó.

\begin{tabular}{ccc}
\hline Densidade real $\left(\mathbf{g} / \mathbf{c m}^{3}\right)$ & Densidade aparente $\left(\mathbf{g} / \mathbf{c m}^{3}\right)$ & Porosidade \\
\hline $1,51 \pm 0,01$ & $0,31 \pm 0,01$ & $0,79 \pm 0,03$
\end{tabular}

Fonte: Própria autoria.

A densidade aparente tem por objetivo expressar a relação entre a massa e o volume da amostra a ser analisada, levando-se em consideração os espaços vazios entre as partículas (preenchidos com ar). Já a densidade real do material sólido analisado expressa a relação entre a massa das folhas de oliva em pó com o volume ocupado por suas partículas, sem considerar o espaço vazio entre as partículas.

De acordo os resultados expressos na Tabela 3, pode-se verificar que, como esperado, a densidade real é maior do que a densidade aparente, com valores médios de 1,51 e $0,31 \mathrm{~g} / \mathrm{cm}^{3}$, respectivamente, indicando a existência de espaço vazio considerável entre as partículas de folhas de oliva em pó (baixa compactação). Os dados de densidade real e aparente conduziram a um valor de porosidade do leito igual a 0,79 .

\subsubsection{Teor de oleuropeína nas folhas de oliva}

Nas análises realizadas em cromatografia líquida de alta eficiência (HPLC) para a quantificação da oleuropeína presente nas folhas de oliva em pó provenientes da Espanha, o teor detectado foi de 6,59 $\pm 0,03 \mathrm{~g} / 100 \mathrm{~g}$ do componente. Este valor é condizente com alguns trabalhos da literatura, como por exemplo no trabalho descrito por Altinyay e Altun (2006), no qual os autores encontraram um teor de $4 \%$ de oleuropeína nas folhas de oliva coletadas de Balıkesir-Edremit, Konya e Osmaniye, material vegetal depositado na Faculdade de Farmácia da Universidade de Ankara, Turquia. PACETTA (2013) também determinou o teor de oleuropeína nas folhas de oliva cultivadas em Estiva Gerbi, no interior de São Paulo, encontrando um valor correspondente a $0,3 \%$ de oleuropeína nas folhas de oliva em pó, valor bem inferior ao encontrado neste trabalho e em demais trabalhos da literatura.

Vale ressaltar que o teor de oleuropeína da matéria-prima utilizada neste trabalho foi determinado segundo a metodologia sugerida por Altinyay e Altun (2006), 
porém realizando-se extrações sequenciais até o esgotamento da oleuropeína nas folhas, como detalhada no item 4.2.2.6. Foram realizadas 4 extrações sequenciais, sendo que somente 2 etapas foram necessárias para extrair toda a oleuropeína (aproximadamente $93 \%$ do total de oleuropeína contida nas folhas na primeira etapa e $3 \%$ na segunda).

\subsubsection{Experimentos de extração com solvente hidroalcoólico}

A Tabela 4 apresenta os resultados para os experimentos de extração da oleuropeína realizados utilizando-se os procedimentos I e II, descritos na seção 4.2.3.

Tabela 4: Rendimento de oleuropeína (RO), teor de oleuropeína (TO) e rendimento global de extrato $(\mathrm{RG})$, para os procedimentos Tipo I e Tipo II.

\begin{tabular}{|c|c|c|c|c|c|}
\hline & $\begin{array}{c}\text { Temperatura } \\
\left({ }^{\circ} \mathbf{C}\right)\end{array}$ & $\begin{array}{l}\text { Método de } \\
\text { extração* }\end{array}$ & $\begin{array}{l}R^{* * *} \\
(\%)\end{array}$ & $\begin{array}{c}\mathrm{TO}^{\star \star} \\
\mathrm{g} \text { de } \mathrm{O} / 100 \mathrm{~g} \\
\text { extrato* }\end{array}$ & $\begin{array}{l}R^{* * *} \\
(\%)\end{array}$ \\
\hline \multirow{5}{*}{ 을 } & 20 & $\mathrm{~A} 1$ & $5,41 \pm 0,49^{\mathrm{BA}}$ & $16,00 \pm 1,53^{\mathrm{BA}}$ & $2,32 \pm 0,02^{\mathrm{BAC}}$ \\
\hline & 30 & $\mathrm{~A} 2$ & $4,87 \pm 0,07^{\mathrm{BC}}$ & $14,52 \pm 0,38^{B}$ & $2,28 \pm 0,03^{\mathrm{BAC}}$ \\
\hline & 40 & A3 & $5,47 \pm 0,08^{\mathrm{BA}}$ & $16,91 \pm 1,00^{\mathrm{BA}}$ & $2,20 \pm 0,08^{\mathrm{BAC}}$ \\
\hline & 50 & A4 & $3,85 \pm 0,49^{\mathrm{BCD}}$ & $12,38 \pm 0,95^{\mathrm{B}}$ & $2,25 \pm 0,3 \mathrm{BAC}$ \\
\hline & 60 & A5 & $6,89 \pm 1,40^{A}$ & $17,05 \pm 2,24^{A}$ & $2,34 \pm 0,66^{\mathrm{BA}}$ \\
\hline \multirow{5}{*}{$\begin{array}{l}= \\
\text { 足 } \\
\text { ie }\end{array}$} & 20 & U1 & $3,62 \pm 0,01 \mathrm{CD}$ & $13,56 \pm 1,29 \mathrm{BA}$ & $1,71 \pm 0,25^{\mathrm{BC}}$ \\
\hline & 30 & U2 & $3,57 \pm 0,10^{C D}$ & $14,24 \pm 1,25^{\mathrm{BA}}$ & $1,78 \pm 0,11^{\mathrm{BAC}}$ \\
\hline & 40 & U3 & $4,55 \pm 1,66^{\mathrm{BCD}}$ & $14,71 \pm 1,89^{\mathrm{BA}}$ & $2,47 \pm 0,03^{A}$ \\
\hline & 50 & U4 & $3,47 \pm 0,02^{\mathrm{CD}}$ & $14,36 \pm 1,76^{\mathrm{BA}}$ & $1,82 \pm 0,00^{\mathrm{BAC}}$ \\
\hline & 60 & U5 & $2,89 \pm 0,35^{\mathrm{D}}$ & $12,04 \pm 0,35^{B}$ & $1,64 \pm 0,15^{C}$ \\
\hline
\end{tabular}

${ }^{\text {*} A ~=~ a g i t a c ̧ a ̃ o ~ m e c a ̂ n i c a ; ~ U ~=~ e x t r a c ̧ a ̃ o ~ c o m ~ u l t r a s s o m . ~}$

**Valores são expressos como a média \pm desvio padrão das análises em triplicata; Na mesma coluna, médias seguidas por letras maiúsculas iguais não diferem entre si ao nível de $5 \%$ de significância pelo Teste de Duncan.

Fonte: Própria autoria. 
Analisando-se os dados apresentados na Tabela 4, observou-se que nos experimentos com agitação mecânica (tipo I), não houve diferença significativa entre os valores de rendimento global (RG) em função da temperatura. No entanto, para as respostas rendimento de oleuropeína $(R O)$ e teor de oleuropeína (TO), verificou-se que os valores à $60^{\circ} \mathrm{C}$ diferiram estatisticamente dos valores à 30 e $50^{\circ} \mathrm{C}$, mas não diferiram dos valores à 20 e $40^{\circ} \mathrm{C}$. Além disso, não foi observada uma tendência, crescente ou decrescente, dessas duas respostas frente à variação de temperatura. Já para os experimentos em banho de ultrassom (tipo II), ocorreu o inverso, ou seja, não houve diferença significativa entre os valores encontrados para as respostas $\mathrm{RO}$ e TO, e alguns valores diferiram entre si para RG. Comparando-se agora cada temperatura nos experimentos tipo I e tipo II, apenas à $60^{\circ} \mathrm{C}$ foi observada diferença significativa para as respostas TO e RG. Para a resposta $R O$, houve diferença para os valores à 20 e $60^{\circ} \mathrm{C}$. Em linhas gerais, observou-se que os valores das respostas para os experimentos com a agitação mecânica foram um pouco maiores do que os valores obtidos para as extrações com o auxílio do ultrassom.

Japón-Luján, Luque-Rodríguez e Luque de Castro (2006) realizaram um estudo utilizando o ultrassom para extrair a oleuropeína. Os autores utilizaram temperatura de $40^{\circ} \mathrm{C}$ e uma mistura de etanol e água $1: 1$, resultando em $2,3 \%$ do composto nos extratos. Segundo Shirsath et al. (2012), um dos parâmetros que merecem total atenção na extração por ultrassom é a frequência do aparelho, pois de acordo com o autor, frequências mais baixas, cerca de $20 \mathrm{kHz}$ são mais eficazes em materiais de origem vegetal, como é o caso da oleuropeína, devido aos efeitos promovidos pela cavitação, pois as bolhas podem implodir mais facilmente que as geradas em alta frequência, facilitando a liberação do composto (ESCALAPEZ et al., 2011). Nesta pesquisa, a frequência do aparelho utilizado foi de $40 \mathrm{kHz}$.

Em um outro estudo realizado por Xie et al. (2013), os autores realizaram a extração da oleuropeína utilizando ultrassom, encontrando melhores rendimentos do composto à concentração de etanol de $75 \%(\mathrm{v} / \mathrm{v})$, temperatura de extração à $50^{\circ} \mathrm{C}$, $600 \mathrm{~W}$ de energia do equipamento, proporção líquido/sólido $30: 1(\mathrm{~mL} / \mathrm{g})$ e pressão de extração a $25 \mathrm{kPa}$, obtendo-se um rendimento de oleuropeína 7,67\% após três extrações. 
Em um estudo realizado por Stamatopoulos et al. (2014), os autores tentaram extrair a oleuropeína através de múltiplos estágios de extração combinado com a técnica de branqueamento, a fim de otimizar o melhor sistema. As folhas de oliveira foram extraídas durante 2 horas em diferentes concentrações de etanol aquoso (20, $40,55,70,80$ e $90 \%$ ) e em temperaturas de 40,60,65, 70 e $85^{\circ} \mathrm{C}$. Todos os extratos etanólicos foram filtrados e analisados quanto ao teor de compostos fenólicos por meio do ensaio de Folin-Ciocalteau. As condições ótimas de extração encontradas no trabalho foram o tempo de 30 minutos a $85^{\circ} \mathrm{C}$ e o rendimento de oleuropeína chegou a ser 23 vezes mais elevada (103,1 mg de oleuropeína/ g de peso seco) em comparação com o rendimento de $4,6 \mathrm{mg}$ de oleuropeína/g de peso seco a $40^{\circ} \mathrm{C}$ e 48 horas. No entanto, segundo a pesquisa, de um ponto de vista econômico, é preferível trabalhar a $40^{\circ} \mathrm{C}$, uma vez que o rendimento da extração foi apenas $17 \%$ mais alto para um duplo aumento de temperatura $\left(85^{\circ} \mathrm{C}\right)$.

De acordo com as literaturas citadas, o rendimento de oleuropeína encontrado neste estudo por meio da agitação magnética e banho de ultrassom em várias faixas de temperatura foram compatíveis se comparados com os trabalhos realizados anteriormente por outros autores, confirmando que não há a necessidade de se utilizar faixas muito altas de temperatura para obter melhor rendimento do composto. Vale ressaltar porém, que os rendimentos obtidos neste trabalho foram prejudicados devido à elevada perda de massa na etapa de evaporação do etanol em evaporador rotativo, em ambos os tipos de procedimentos (tipo I e tipo II), que em média foi de $30 \%$ para o tipo I e $23 \%$ para o tipo II. Isto ocorreu devido à dificuldade para retirar todo o extrato seco das folhas de oliva, pois parte da massa ficou retida nas paredes do recipiente, impedindo assim que se obtivesse um resultado conciso nos processos de extração.

Diante da constatação de que o aumento da temperatura e a utilização do ultrassom não trouxeram vantagens ao processo, e diante do problema de perda de massa observado nos experimentos tipo I e tipo II, decidiu-se pela modificação da metodologia (procedimento tipo III), como descrito no item 4.2.3, no qual as extrações foram realizadas com agitação magnética à temperatura ambiente, variando da razão folhas:solvente, com e sem a adição de ácido, sendo que o etanol foi removido diretamente em estufa à vácuo (ao invés do evaporador rotativo) já no recipiente onde o extrato seria liofilizado. 
A adição do ácido acético ao meio reacional teve por objetivo estabilizar a molécula de oleuropeína, que durante a extração pode se converter em hidroxitirosol, dificultando a quantificação do composto. No trabalho prévio de Pacetta (2013), já foi constatado que a adição de ácido acético trazia efeitos positivos nos resultados do processo e, por isso, os experimentos tipo I e tipo II foram realizados com a adição de ácido. Porém, como a matéria-prima utilizada neste trabalho continha um teor de oleuropeína muito maior, decidiu-se por verificar se essa adição traria efeitos significativos na extração da oleuropeína através dos experimentos tipo III.

Os resultados referentes ao procedimento tipo III estão apresentados na Tabela 5. Os resultados estão expressos como rendimento de oleuropeína (RO), teor de oleuropeína nos extratos (TO) e rendimento global (RO):

Tabela 5: Rendimento de oleuropeína (RO), teor de oleuropeína (TO) e rendimento global de extrato $(R G)$, para o procedimento Tipo III.

\begin{tabular}{|c|c|c|c|c|}
\hline & $\begin{array}{l}\text { Razão folha: } \\
\text { etanol }\end{array}$ & $\begin{array}{l}\text { RO* } \\
(\%)\end{array}$ & $\begin{array}{c}\text { TO}^{*} \\
\text { g de } 0 / 100 \mathrm{~g} \\
\text { extrato* }^{*}\end{array}$ & $\begin{array}{l}R^{*} \\
(\%)\end{array}$ \\
\hline \multirow{3}{*}{ 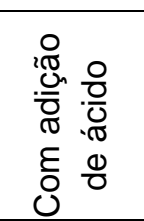 } & $1: 3$ & $28,51 \pm 4,13^{\mathrm{D}}$ & $18,11 \pm 2,42^{\mathrm{A}}$ & $10,77 \pm 0,12^{\mathrm{E}}$ \\
\hline & $1: 6$ & $46,12 \pm 3,56^{\mathrm{C}}$ & $16,82 \pm 0,92^{A}$ & $18,76 \pm 0,45^{D}$ \\
\hline & $1: 8$ & $60,95 \pm 0,11^{\mathrm{B}}$ & $12,50 \pm 0,12^{\mathrm{B}}$ & $33,39 \pm 0,25^{A}$ \\
\hline \multirow{3}{*}{ 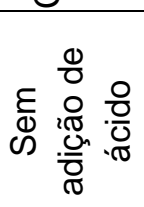 } & $1: 3$ & $12,35 \pm 0,69^{E}$ & $8,30 \pm 0,58^{C}$ & $10,23 \pm 1,28^{\mathrm{E}}$ \\
\hline & $1: 6$ & $30,32 \pm 2,15^{\mathrm{D}}$ & $9,89 \pm 0,73^{\mathrm{CB}}$ & $20,99 \pm 0,07^{c}$ \\
\hline & $1: 8$ & $67,71 \pm 0,00^{A}$ & $10,97 \pm 0,27^{\mathrm{B}}$ & $25,94 \pm 0,63^{B}$ \\
\hline
\end{tabular}

*Valores são expressos como a média \pm desvio padrão das análises em triplicata; Na mesma coluna, médias seguidas por letras maiúsculas iguais não diferem entre si ao nível de $5 \%$ de significância pelo Teste de Duncan.

Fonte: Própria autoria.

Através dos resultados apresentados na Tabela 5, verificou-se que a presença do ácido acético nas extrações atuou de maneira positiva sobre o rendimento de oleuropeína $(R O)$ nas razões folhas:solvente, iguais a 1:3 e 1:6. Porém, na maior quantidade de solvente utilizada (razão 1:8), o valor de RO foi maior sem a presença 
de ácido no procedimento, sendo que todos os resultados dessa resposta diferiram entre si estatisticamente. Para a resposta teor de oleuropeína nos extratos (TO), também se observou a influência positiva da presença do ácido em todas as razões folha:solvente, porém na razão 1:8 os valores de TO não diferiram estatisticamente entre si. Os rendimentos globais ( $R G$ ) também foram um pouco maiores com a presença de ácido, porém não havendo diferença estatística entre os valores da razão $1: 3$.

Pode-se observar também na Tabela 5, tanto para os procedimentos com ácido como para os sem ácido, que o aumento da quantidade de solvente na extração conduz ao aumento do rendimento de oleuropeína (RO). Este resultado já era esperado, pois quanto maior a quantidade de solvente, maior quantidade de soluto este será capaz de solubilizar.

Em relação ao teor de oleuropeína nos extratos, nota-se que, para os experimentos com ácido, quanto maior a quantidade de solvente, menor o teor de oleuropeína. De fato, os valores de TO estão relacionados aos valores de rendimento global. Quando uma quantidade maior de solvente foi utilizada, extraiu-se mais oleuropeína, mas também extraíram-se outros compostos, originando em uma massa maior de extrato (maior rendimento). Como os valores de TO são obtidos pela massa de oleuropeína no extrato (obtida por manipulação dos resultados do HPLC) dividida pela massa total de extrato, era de se esperar o comportamento observado neste caso. Para os experimentos sem ácido, o inverso foi observado nos valores de TO, porém com pouca diferença significativa entre si.

Vale ressaltar que a mudança de procedimento para os experimentos tipo III forneceu melhores resultados para as respostas $R O$ e RG, visto que o solvente foi removido do extrato diretamente no recipiente onde seria liofilizado, eliminando os erros pela perda de massa (como ocorreu nos experimentos tipo I e tipo II). Apenas para a resposta TO, não se observou tal melhora, porém como este valor depende da massa de extrato (e houve muita perda nos experimentos tipo I e tipo II), não se pode afirmar se os valores de TO apresentados na Tabela 4 são comparáveis aos apresentados na Tabela 5.

Mkaouar et al. (2015), realizaram um estudo para verificar as condições de extração de compostos fenólicos das folhas de oliveira, avaliando parâmetros como concentração do solvente, temperatura, proporção sólido:líquido e tempo de extração 
de 3 horas, através da técnica de DIC (do francês "Détente instantanée Contrôlée queda de pressão instantânea controlada), a qual sujeita a matéria-prima a um curto período de tempo em um vapor saturado, seguido de uma repentina queda de pressão de vácuo, induzindo assim à expansão do material vegetal, tornando-as mais adeptas à transferência de massa. Os resultados foram analisados em Ultra Performance Liquid Chromatography (UPLC) e os autores puderam verificar que a variável que mais influenciou no rendimento dos polifenóis foi a concentração do etanol, porém a temperatura e a relação folha:solvente apresentaram poucas diferenças significativas, sendo o efeito positivo do etanol relacionado possivelmente com a alta afinidade dos compostos fenólicos presentes nas folhas com o solvente. Nos extratos das folhas de oliva, o composto majoritário encontrado foi a oleuropeína (cerca de 90,31\%) seguido de outros como o verbascosídeo, hidroxitirosol, tirosol e ácido vanílico. As melhores condições encontradas para a extração dos compostos foi $95,59 \%$ de etanol à $55^{\circ} \mathrm{C}$. De acordo com esses autores, outros fatores como natureza do solvente e tempo de extração também podem levar à diferentes rendimentos dos compostos fenólicos.

Bilgin e Sahin (2013) também estudaram a extração de compostos fenólicos das folhas de oliveira, mas utilizando o metanol como solvente, em técnicas como a homogeneização e extração por ultrassom. Os autores encontraram melhores resultados (sendo o teor de fenólicos totais expressos em equivalentes de ácido gálico (GAE) por gramas de folhas secas) para o rendimento dos extratos fenólicos com a técnica de homogeneização, com valores entre 102,27 à 443,16 mg/g (10,11 - 61,66 $\mathrm{mg} \mathrm{GAE/g}$ de folha seca), enquanto que para o ultrassom, variou entre 88,75 e 350,82 $\mathrm{mg} / \mathrm{g}(7,35$ - 38,66 mg GAE/g de folha seca).

Apesar de algumas pesquisas apontarem o metanol como um bom solvente para extrair a oleuropeína (fato que justifica sua utilização na metodologia de quantificação do composto), este possui alta toxicidade, e pode comprometer a utilização dos extratos em alimentos.

Vale ressaltar que o procedimento tipo III também foi utilizado para uma extração teste com o solvente água pura, na proporção folhas:solvente igual a 1:8, resultando em um rendimento de oleuropeína $(\mathrm{RO})$ igual a $(3,47 \pm 0,28) \%$, um teor de oleuropeína no extrato (TO) igual a $(1,45 \pm 0,16) \mathrm{g}$ de oleuropeína/100 $\mathrm{g}$ de extrato um rendimento global $(R G)$ igual a $(15,71 \pm 0,20) \%$. Como os valores obtidos não foram satisfatórios, não foram realizadas demais análises a fim de se evitar o gasto 
de materiais e reagentes, já que, provavelmente, a água não atuou como bom solvente de extração dos compostos bioativos das folhas de oliva.

Por fim, selecionou-se uma das condições experimentais utilizadas no experimento tipo III para a realização do procedimento tipo IV (descrito na seção 4.2.3), no qual foram realizadas quatro extrações sucessivas com solvente novo em cada etapa. Optou-se pela razão folha:solvente igual a 1:3, na presença de ácido acético, pois essa condição requer uma menor quantidade de solvente e proporciona a produção de um extrato com o maior teor de oleuropeína (TO), apesar de também ter fornecido os menores valores de $R O$ e $R G$ em comparação com as razões 1:6 e 1:8. Os resultados obtidos em cada etapa de extração sequenciada estão apresentados na Tabela 6:

Tabela 6: Rendimento de oleuropeína (RO), teor de oleuropeína (TO) e rendimento global de extrato (RG), para o procedimento Tipo IV.

\begin{tabular}{cccc}
\hline Etapa de extração & $\begin{array}{c}\mathbf{R O}^{*} \\
(\%)\end{array}$ & $\begin{array}{c}\text { TO}^{*} \\
\mathbf{g ~ d e ~} \mathbf{O} / \mathbf{1 0 0 g} \text { extrato*}\end{array}$ & $\begin{array}{c}\mathbf{R G}^{*} \\
\mathbf{( \% )}\end{array}$ \\
\hline 1 & $38,11 \pm 3,09$ & $16,77 \pm 1,76$ & $15,58 \pm 0,37$ \\
2 & $12,55 \pm 1,25$ & $13,87 \pm 1,40$ & $6,20 \pm 0,01$ \\
3 & $6,32 \pm 0,77$ & $10,04 \pm 3,24$ & $4,45 \pm 0,91$ \\
4 & $4,95 \pm 0,21$ & $8,87 \pm 0,17$ & $3,83 \pm 0,24$
\end{tabular}

*Valores são expressos como a média \pm desvio padrão das análises em triplicata.

Fonte: Própria autoria.

De acordo com os resultados apresentados na Tabela 6 , verificou-se que a oleuropeína ainda permanece nas folhas de oliva mesmo após quatro extrações sequenciais. Observou-se também que os valores de RO, TO e RG diminuíram a cada etapa de extração, mostrando que dependem do teor inicial de oleuropeína na matéria-prima. Vale ressaltar que o cálculo da massa de oleuropeína na matéria-prima utilizada na segunda etapa foi realizado através de balanço de massa, utilizando-se o valor conhecido do teor original do composto nas folhas de oliva e o teor quantificado no extrato proveniente da primeira etapa. O mesmo procedimento foi adotado para 0 
cálculo das massas de oleuropeína presentes nas folhas utilizadas na terceira e na quarta etapa.

Nas Figuras 13 a 16 é possível observar que conforme a oleuropeína era extraída da massa resultante da extração anterior, a coloração das folhas ficavam cada vez mais claras, devido à perda de seus componentes em cada etapa da extração.

Figura 13: Primeira extração sequencial da oleuropeína.

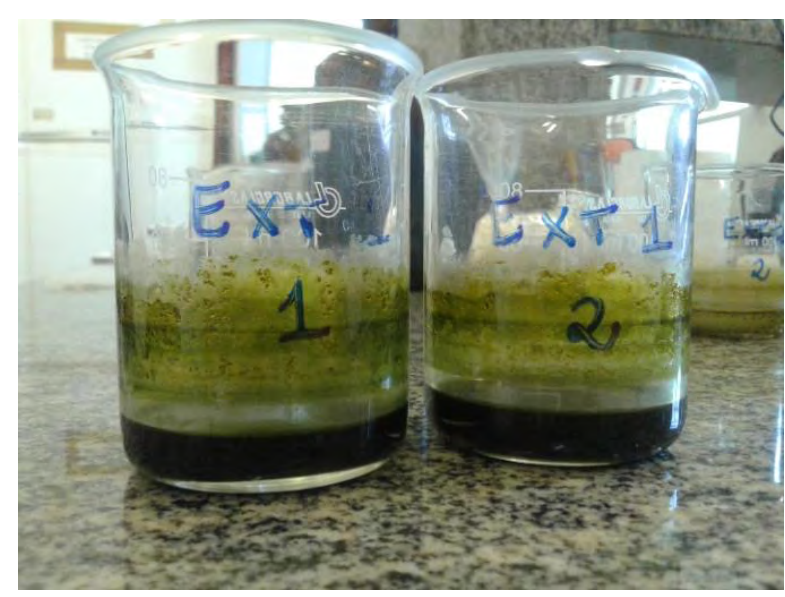

Fonte: Própria autoria.

Figura 14: Segunda extração sequencial da oleuropeína.

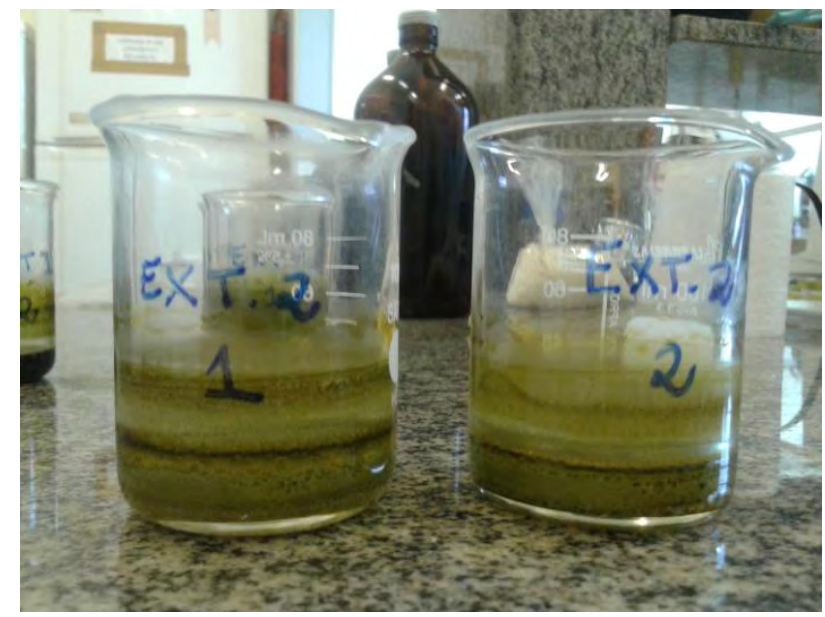

Fonte: Própria autoria. 
Figura 15: Terceira extração sequencial da oleuropeína.

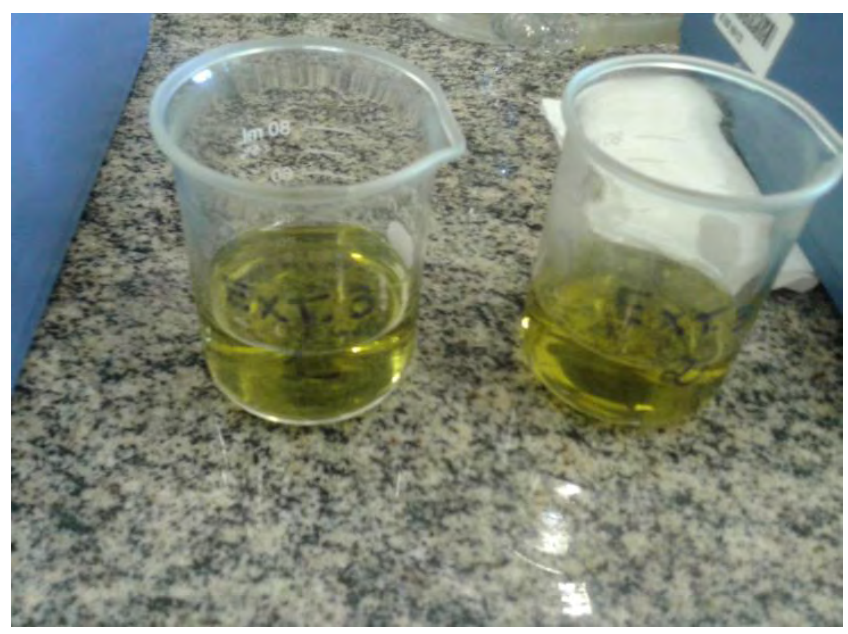

Fonte: Própria autoria.

Figura 16: Quarta extração sequencial da oleuropeína.

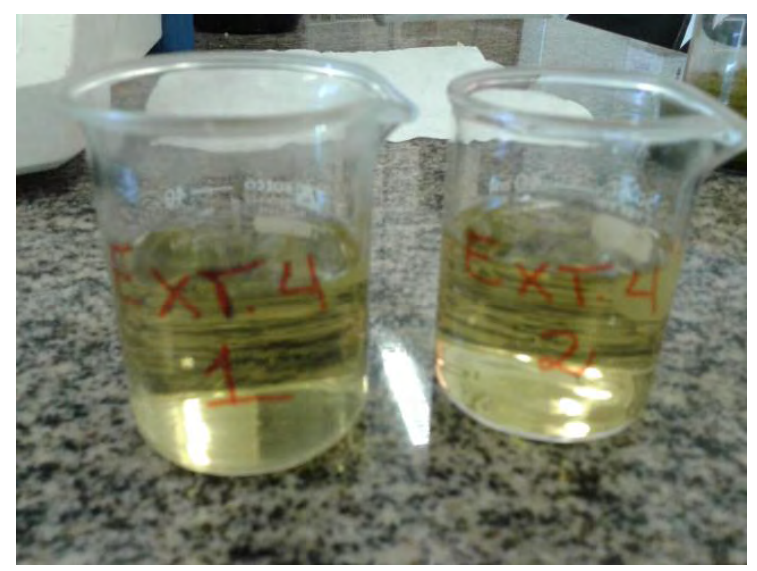

Fonte: Própria autoria. 


\subsection{Estudo da estabilidade oxidativa}

\subsubsection{Caracterização dos óleos vegetais utilizados}

Na Tabela 7 estão apresentados os resultados referentes à composição em ácidos graxos para os azeites de oliva extra-virgem e comum, determinados neste trabalho, e para os óleos de girassol bruto (determinado por Scharlack (2015)) e refinado (obtido por Dias et al. (2015)).

Tabela 7: Perfil de ácidos graxos dos azeites de oliva extra-virgem e comum, e dos óleos de girassol bruto e refinado (em massa).

\begin{tabular}{ccccc}
\hline \multirow{2}{*}{$\begin{array}{c}\text { Ácido graxo } \\
\left(\mathbf{C} \mathbf{x}: \mathbf{y}^{\star}\right)\end{array}$} & \multicolumn{2}{c}{ Azeite de oliva } & \multicolumn{2}{c}{ Óleo de girassol } \\
\cline { 2 - 5 } & Extra-virgem & Comum & Bruto $^{\star \star}$ & Refinado*** $^{\star 2}$ \\
\hline Palmítico (C16:0) & $11,60 \pm 0,13$ & $14,14 \pm 1,01$ & 5,68 & 6,30 \\
Palmitoléico (C16:1) & $0,82 \pm 0,03$ & $3,83 \pm 0,54$ & $n d$ & 0,12 \\
Esteárico (C18:0) & $2,74 \pm 0,05$ & $2,46 \pm 0,05$ & 4,64 & 3,30 \\
Oléico (C18:1) & $75,30 \pm 0,66$ & $72,05 \pm 1,78$ & 22,26 & 35,95 \\
Linoléico (C18:2) & $10,35 \pm 0,57$ & $11,35 \pm 0,72$ & 67,43 & 52,75 \\
Linolênico (C18:3) & $0,77 \pm 0,01$ & $n d$ & $n d$ & 0,77 \\
\hline
\end{tabular}

${ }^{*} \mathrm{C} x: \mathrm{y} ; \mathrm{x}$ = número de carbonos; $\mathrm{y}=$ número de duplas ligações.

**Óleo de girassol bruto Caramuru - Valores determinados por Scharlack (2015); nd = não detectado.

${ }^{\star * \star}$ Óleo de girassol refinado - Valores disponíveis em Dias et al. (2015).

Fonte: Própria autoria.

Avaliando-se o perfil de ácidos graxos para os azeites de oliva extra-virgem e comum e para o óleo de girassol, verificou-se a presença de alguns níveis de insaturações, o que significa que são óleos vegetais muito vulneráveis à oxidação. Daí a importância em se estudar a adição de antioxidantes naturais, sem afetar sua composição química e nutricional, aumentando assim, sua estabilidade oxidativa. 


\subsubsection{Acidez livre}

A Tabela 8 apresenta os resultados das análises de acidez livre realizadas para os azeites (Gallo) extra-virgem e comum, e para os óleos de girassol refinado (Liza) e bruto (Caramuru):

Tabela 8: Resultados das análises de acidez dos óleos vegetais.

\begin{tabular}{cc}
\hline Amostras & Acidez (\% ácido oléico) $^{\star}$ \\
\hline Azeite extra-virgem & $0,56 \pm 0,01$ \\
Azeite comum & $0,86 \pm 0,02$ \\
Girassol refinado & $0,14 \pm 0,01$ \\
Girassol bruto & $0,64 \pm 0,01$
\end{tabular}

${ }^{*}$ Os valores são expressos como o desvio padrão médio \pm das análises em duplicata.

Fonte: Própria autoria.

De acordo com a Resolução número 482 da Anvisa, de 23 de setembro de 1999, o azeite de oliva extra-virgem não deve possuir acidez, expressa em ácido oléico, superior a $1 \mathrm{~g} / 100 \mathrm{~g}$ e o azeite de oliva comum, acidez não superior a 3,3 $\mathrm{g} / 100 \mathrm{~g}$ de azeite. Para o óleo de girassol, a Anvisa determina que o óleo de girassol refinado não deve ultrapassar $0,3 \mathrm{~g}$ de ácido oléico/100 g de óleo e o bruto, máximo de $2 \mathrm{~g} / 100 \mathrm{~g}$ de óleo.

A Tabela 8 mostra que os resultados encontrados para a acidez dos óleos vegetais analisados estão de acordo com os padrões estabelecidos pela Anvisa, que é o órgão responsável pela fiscalização sanitária de produtos que são oferecidos à população, de maneira a identificar problemas e iniciar ações que evitem ou minimizem os riscos à saúde.

Embora o grau de acidez não tenha relação direta com o sabor do azeite de oliva e do óleo de girassol, é importante conhecer se o produto está próprio para o consumo humano, devendo apresentar, portanto, uma acidez de acordo com as estabelecidas pelos órgãos competentes. 


\subsubsection{Aplicação dos extratos de folhas de oliva em óleos vegetais para a avaliação da estabilidade oxidativa}

Para a realização dos testes de estabilidade oxidativa, foi utilizado o extrato com o maior teor de oleuropeína, proveniente de um dos experimentos tipo III (com razão folhas:solvente igual a 1:3, com a presença de ácido). Massas conhecidas desse extrato liofilizado foram adicionadas aos óleos vegetais selecionados para o estudo (azeite de oliva e óleo de girassol) de modo a fornecer uma quantidade do composto ativo dentro da faixa utilizada em testes similares descritos por Jimenez et al. (2011). A Tabela 9 apresenta os tempos de indução obtidos para os óleos vegetais em três condições: (1) sem a adição dos extratos de folhas de oliva; (2) com a adição de extrato; (3) com o dobro da massa de extrato adicionado em (2). O período de indução pode ser definido como o tempo para atingir o nível de rancidez que seja detectável ou mudança na taxa de oxidação ((DROZDOWSKI \& SZUKALSKA, 1987; FRANKEL, 1993; GARCIA MESA et al., 1993; HILL, 1994; GUTIÉRREZ ROSALES, 1989; LAUBLI \& BRUTTEL, 1986).

Vale ressaltar que as condições 1 e 3 foram utilizadas apenas para o azeite de oliva, sendo que os dados do tempo de indução para o óleo de girassol na condição 1 foram obtidos por Scharlack (2015). 
Tabela 9: Resultados dos tempos de indução obtidos no aparelho Rancimat para as amostras de óleos vegetais com e sem a adição dos extratos de folhas de oliva.

\begin{tabular}{|c|c|c|c|}
\hline Amostras & $\begin{array}{c}\text { Condição } \\
\text { experimental* }\end{array}$ & $\begin{array}{l}\text { Tempos indução } \\
(h)^{\star \star}\end{array}$ & Literatura \\
\hline \multirow{3}{*}{$\begin{array}{c}\text { Azeite extra- } \\
\text { virgem }\end{array}$} & 1 & $24,22 \pm 0,41^{B}$ & 21,3 a $43,5^{1}$ \\
\hline & 2 & $27,15 \pm 1,14^{\mathrm{A}}$ & nd \\
\hline & 3 & $25,54 \pm 0,08^{B A}$ & nd \\
\hline \multirow{3}{*}{ Azeite comum } & 1 & $14,26 \pm 0,32^{D}$ & $9,0^{2}$ \\
\hline & 2 & $16,52 \pm 0,37^{C}$ & $13,5^{2}$ \\
\hline & 3 & $17,43 \pm 0,08^{C}$ & nd \\
\hline Óleo de girassol & 1 & $5,84^{3} \pm 0,04^{C}$ & \\
\hline bruto & 2 & $4,22 \pm 0,32^{A}$ & nd \\
\hline Óleo de girassol & 1 & $4,75^{3} \pm 0,05^{\mathrm{BC}}$ & \\
\hline refinado & 2 & $4,40 \pm 0,08^{A}$ & $21,1^{4}$ \\
\hline
\end{tabular}

* (1) sem a adição dos extratos de folhas de oliva; (2) com a adição de massa conhecida de extrato de oliva; (3) com a adição do dobro da massa de extrato utilizada em (2).

** Médias seguidas por letra maiúscula iguais na mesma coluna não diferem entre si ao nível de $5 \%$ de significância pelo Teste de Duncan.

1: Krichene et al. (2010); ${ }^{2}$ Salta et al. (2007); ${ }^{3}$ Scharlack (2015); ${ }^{4}$ Jimenez et al. (2011).

Fonte: Própria autoria.

De acordo com os resultados apresentados na Tabela 9, a adição de extratos de folha de oliva aumentou o tempo de indução, tanto para o azeite extra-virgem como para o comum, porém a adição do dobro de extrato (condição 3) não trouxe vantagens para o aumento da estabilidade oxidativa, visto que os tempos de indução obtidos nesta condição não diferem estatisticamente dos valores obtidos na condição 2. Notase também que os tempos de indução obtidos neste trabalho para os dois tipos de azeite foram maiores do que os encontrados na literatura, indicando que os extratos contendo oleuropeína, obtidos da extração das folhas de oliva em pó realizaram atividade antioxidante sobre as amostras de azeite, aumentando sua estabilidade oxidativa. 
Já para as amostras de óleo de girassol, notou-se que os tempos de indução obtidos na presença de extrato de folhas de oliva foram menores do que os obtidos por Scharlack (2015) sem a adição de extrato. De fato, como as amostras de óleo de girassol estavam armazenadas a um certo tempo, desde as análises realizadas por Scharlack (2015), estas podem ter se degradado e o período de indução pode ter diminuído também. Infelizmente, devido à difícil disponibilidade do equipamento Rancimat na época dos experimentos, esta análise na condição 1 não pôde ser refeita para novas amostras de óleo de girassol.

Jorge (2010) realizou análises de estabilidade oxidativa em diferentes marcas de azeites de oliva e encontrou valores dos tempos de indução (em horas), variando de 9,04 à 42,44. Krichene et al. (2010) estudaram a estabilidade oxidativa de azeites de oliva e o comportamento dos seus compostos antioxidantes naturais durante 0 armazenamento. Os tempos de indução (em horas) das amostras de azeites virgens encontrados pelos autores variaram de 21,3 à 43,5.

Em um trabalho publicado por Salta et al. (2007), os autores avaliaram a estabilidade de óleos vegetais enriquecidos com extratos de folhas de oliva, os quais continham cerca de $185 \mathrm{mg}$ de oleuropeína/kg de óleo. Antes da adição dos extratos no azeite de oliva e no óleo de palma, as amostras apresentaram tempos de indução (em horas) de 13,3 e 24 horas, respectivamente. Após o enriquecimento dos óleos com os extratos, os mesmos obtiveram estabilidade de 20,8 e 43,1 horas, respectivamente, confirmando que a adição dos extratos de folhas de oliva em óleos vegetais contribui para o aumento de sua estabilidade oxidativa.

Jimenez et al. (2011) reportaram resultados de estabilidade oxidativa em óleos de girassol, canola e soja adicionados de três tipos de extratos de folhas de oliva: extrato hidroalcoólico, suco pressionado e extratos obtidos por $\mathrm{CO}_{2}$ supercrítico, sendo que cada uma das amostras de extratos continham uma concentração de polifenóis de 250 e $630 \mathrm{mg} \mathrm{CAE} / \mathrm{kg}$ de óleo e os resultados de estabilidade oxidativa foram determinados pelo aparelho Rancimat. Para os extratos que continham a concentração de $250 \mathrm{mg} \mathrm{CAE} / \mathrm{kg}$ de óleo, os tempos de indução (em horas) do óleo de girassol variou de 21,1, 26,3 e 2,7 com os extratos hidroalcoólicos, extrato obtido de $\mathrm{CO}_{2}$ supercrítico e suco pressionado, respectivamente. Para o óleo de canola, na mesma ordem dos extratos, os resultados foram 9,5, 12,6 e 1,8. Para o óleo de soja, tempos de indução de 6,7, 6,9 e 1,7 foram encontrados na mesma ordem dos extratos 
descrita acima. Os autores avaliaram também a concentração de polifenóis de 630 $\mathrm{mg} \mathrm{CAE} / \mathrm{kg}$ de óleo em cada um dos óleos. O óleo de girassol com extrato hidroalcoólico, $\mathrm{CO}_{2}$ supercrítico e suco pressionado obteve tempos de indução variando de 30,7, 35,1 e 3,0. O óleo de canola, 11,0, 13,4 e 2,0 e para o óleo de soja, tempos de 7,6, 8,4 e 1,4, respectivamente para a ordem dos extratos citadas.

Adicionalmente aos experimentos descritos anteriormente, também foram realizados testes de estabilidade oxidativa através da adição direta de folhas de oliva em pó, para se verificar se as folhas puras também exerciam atividade antioxidante sobre os azeites. Para o azeite extra-virgem, o tempo de indução obtido com a adição de uma massa conhecida de folha em pó foi de $(24,81 \pm 0,15) \mathrm{h}$, e com o dobro da massa foi de $(24,39 \pm 0,37) \mathrm{h}$. Comparando-se esses valores com o tempo de indução para a amostra pura (Tabela 9 ), que foi de $(24,22 \pm 0,41) \mathrm{h}$, verificou-se que não diferiram estatisticamente entre si, indicando que a adição da folha em pó não aumentou a estabilidade oxidativa do azeite extra-virgem. Já para o azeite comum, a adição de uma massa conhecida de folha em pó resultou em um aumento do tempo de indução para $(16,66 \pm 0,08) \mathrm{h}$, e com o dobro da massa de folha, o valor foi de $(15,98 \pm 0,65) h$. Ambos não diferiram entre si, mas diferiram estatisticamente e foram maiores do que o valor obtido para o azeite comum puro (Tabela 9$)$, que foi de $(14,26$ $\pm 0,32) \mathrm{h}$.

A Figura 17 apresenta uma comparação entre os tempos de indução obtidos para os azeites extra-virgem e comum nas três condições: puros, com a adição de extrato ou folhas em pó, com o dobro de extrato ou folhas em pó. 
Figura 17: Comparação da adição de extrato e de folhas de oliva aos azeites.

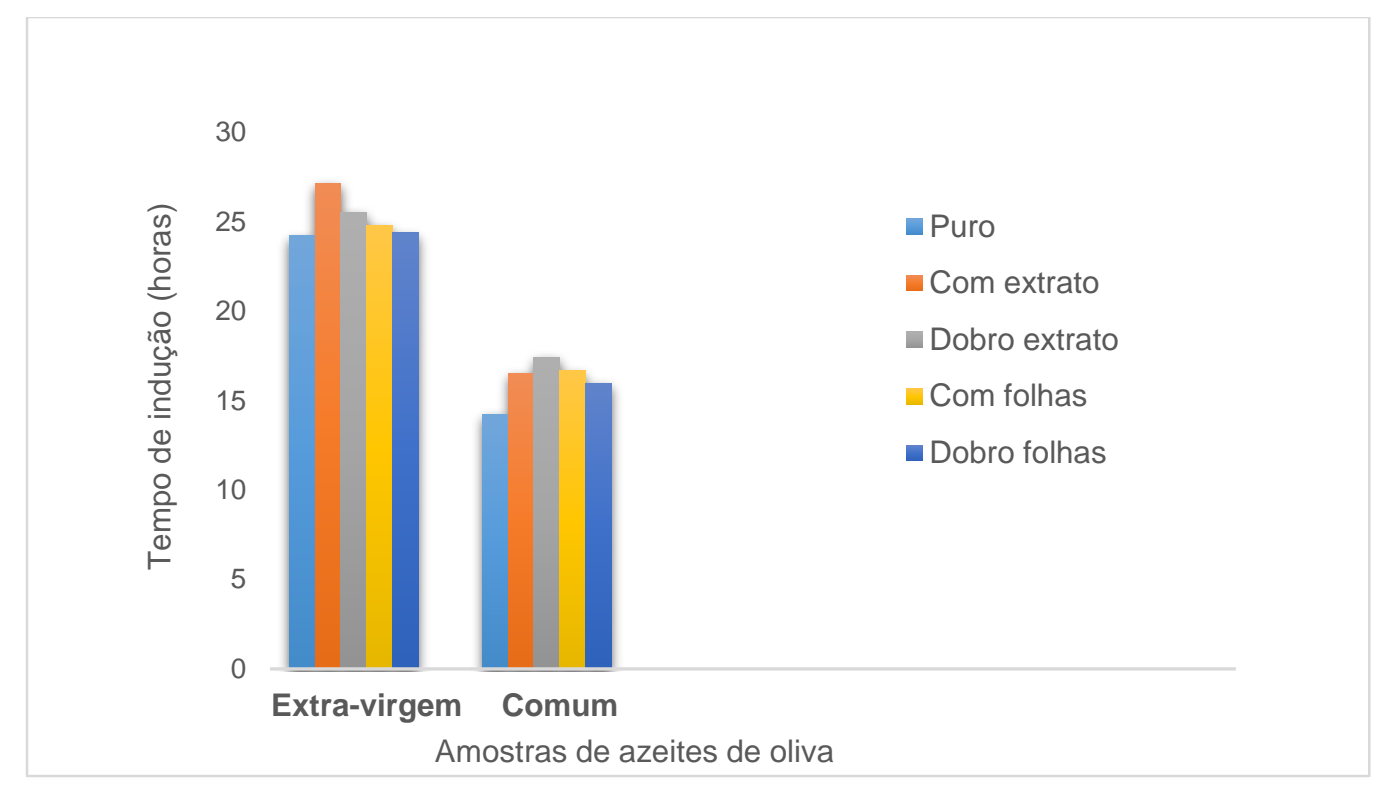

Fonte: Própria autoria.

Pela Figura 17, nota-se que as amostras de azeite extra-virgem adicionadas de extrato diferiram estatisticamente de todas as outras amostras, apresentando maior estabilidade (tempo de indução igual a 27,15 horas) em relação às amostras onde foram adicionadas as folhas em pó. Já para o azeite comum, a diferença entre os tempos de indução com a adição de extrato e com a adição de folhas não foi significativa, mas estes foram diferentes estatisticamente das amostras com o dobro de folhas e do azeite puro.

Os resultados expressos neste trabalho indicaram que a adição de extrato de folhas de oliva em óleos pode ser positiva para o aumento da estabilidade oxidativa de azeite de oliva, porém, é necessário um estudo mais aprofundado acerca das condições de contato entre os óleos e o extrato, por exemplo. 


\section{CONCLUSÕES}

Com base nos resultados obtidos para os experimentos de extração da oleuropeína das folhas de oliva utilizando solvente hidroalcoólico (etanol:água 70:30, $\mathrm{v} / \mathrm{v}$ ), por meio de maceração e ultrassom em diferentes condições de temperatura (20, $30,40,50$ e $60^{\circ} \mathrm{C}$ ), pôde-se concluir que os rendimentos do composto fenólico de interesse, em linhas gerais, não foram significativamente diferentes quando submetidas à diferentes faixas de temperatura, assim como não houve a influência da comparação entre os dois equipamentos utilizados, visto que os rendimentos foram bem próximos tanto utilizando o agitador mecânico quanto o banho de ultrassom, já que os valores encontrados para o RO foram de 3,85 à 6,89\% de oleuropeína por meio de agitação e de 2,89 à 4,55\% de oleuropeína através do banho de ultrassom. Os baixos rendimentos obtidos ocorreram também devido à dificuldade para a retirada da massa seca das folhas do balão volumétrico, resultante da evaporação do etanol em evaporador rotativo, fato este que levou à opção de uma nova metodologia para reduzir maiores perdas nos rendimentos, realizando-se a secagem do etanol em estufa à vácuo, procedimento que se mostrou muito eficiente, pois as perdas da massa seca das folhas para posterior liofilização foram mínimas.

Com relação às extrações da oleuropeína em diferentes proporções de massa e solvente (1:8, 1:6 e 1:3) e a verificação da influência da adição do ácido acético ao meio reacional, os maiores rendimentos de oleuropeína encontrados foram para a razão 1:8, com valores entre 60,95 e 67,71\% do composto, com e sem adição de ácido acético, respectivamente. Verificou-se que a presença do ácido acético nas extrações atuou de maneira positiva sobre o rendimento de oleuropeína (RO) nas razões folhas:solvente, iguais a 1:3 e 1:6. Porém, na maior quantidade de solvente utilizada (razão 1:8), o valor de RO foi maior sem a presença de ácido no procedimento, sendo que todos os resultados dessa resposta diferiram entre si estatisticamente.

$\mathrm{Na}$ realização das extrações sequenciais das folhas de oliva em pó utilizando etanol hidroalcoólico foi possível a constatação da detecção da oleuropeína nos extratos mesmo após várias extrações sequenciadas (neste trabalho, realizaram-se 4 extrações sequenciais da mesma folha), indicando que é necessário um estudo mais aprofundado sobre o número de etapas necessárias para esgotar a matéria-prima.

$\mathrm{Na}$ avaliação da atuação da oleuropeína como um antioxidante natural, esta se mostrou eficiente quando os extratos foram adicionados às amostras de azeites de 
oliva analisados, aumentando a estabilidade oxidativa dos mesmos, quando comparadas com as literaturas disponíveis e às amostras não enriquecidas do extrato hidroalcoólico das folhas de oliva. Para o azeite extra-virgem, os extratos aumentaram sua estabilidade em aproximadamente 3 horas, e para o azeite de oliva comum, 0 aumento foi de pouco mais de 2 horas. Para o óleo de girassol refinado e bruto também avaliados, os resultados com a adição dos extratos não se apresentaram de forma positiva, pois estes não conseguiram aumentar a estabilidade oxidativa das mesmas, devido ao fato das amostras já se apresentarem, possivelmente, em estado de degradação.

De acordo com os resultados apresentados neste trabalho, pode-se concluir que há a possibilidade da substituição dos antioxidantes sintéticos disponíveis no mercado por um antioxidante natural oriundo de fontes vegetais, pois além de não oferecer riscos à saúde, a oleuropeína também têm se mostrado com outras propriedades, atuando como um agente antimicrobiano, antiviral e anti-inflamatória, segundo a literatura. A utilização de um solvente seguro e não tóxico também apontou resultados positivos referentes aos rendimentos de oleuropeína obtidos, alternativa para a substituição em relação ao metanol, (solvente mais comum utilizado para extrair o composto), reduzindo assim os impactos ambientais, além de não oferecer quaisquer riscos à saúde. 


\section{SUGESTÕES PARA TRABALHOS FUTUROS}

Experimentos de extração da oleuropeína realizando-se a extração sequencial das folhas de oliva podem ser estudados com maior intensidade, podendo-se estabelecer também outros componentes que ainda permanecem nas folhas de oliva e que poderiam ser aproveitados, minimizando perdas de componentes bioativos.

Sugere-se também a aplicação dos extratos de folhas de oliva em outros tipos de óleos vegetais e em outras formulações alimentícias, para uma avaliação e estudos mais profundos em relação à sua propriedade de atuação como um antioxidante natural. 


\section{REFERÊNCIAS}

ABAZA, L. et al. Introdution of growth inhibition and differentiation of human leukemia $\mathrm{HL}-60$ cells by a tunisian gerboui olive leaf extract. Bioscience, Biotecnology and Biochemistry, Oxfordshire, v. 71, p. 1306-1312, 2007.

AHMAD-QASEM, M. U. et al. Kinetic and compositional study of phenolic extraction from olive leaves (var. Serrana) by using power ultrasound. Innovative Food Science and Emerging Technologies, Amsterdam, v. 17, p. 120-129, 2013.

AL-AZZAWIE, H. F.; ALHAMDANI, M. S. S. Hipoglicemic and antioxidant effect of oleuropein in alloxan-diabetic rabbits. Life Sciences, Philadelphia, v. 78, p. 13711377, 2006.

ALTINYAY, C.; ALTUN, M. L. HPLC analysis of oleuropein in Olea Europaea L. Sciences, Washington, v. 35, p. 1 - 11, 2006.

AGÊNCIA NACIONAL DE VIGILÂNCIA SANITÁRIA - ANVISA. Resolução RDC no 482, de 23 de setembro de 1999. Regulamento técnico para fixação de identidade e qualidade de óleos e gorduras vegetais. Diário Oficial da União, Poder Executivo, Brasília, DF, 23 de setembro de 2005.

AMERICAN OIL CHEMISTS' SOCIETY - AOCS. Official Methods and recommended practices of the American Oil Chemists' Society. 3rd ed. Champaing: Press, 1998, v. 1-2.

AMERICAN SOCIETY OF AGRICULTURAL AND BIOLOGICAL ENGINEERS ASABE. ANSI/ASAE S319.4 - Methods of determination and spressing fineness of feed materials by sieving. St. Joseph, MI: ASABE, 1998.

AOUIDI, F. et al. Rapid quantitative determination of oleuropein in olive leaves (Olea europaea) using mid-infrared spectroscopy combined with chemometric analyses. Industrial Crops and Products, Amsterdam, v. 37, p. 292-297, 2012.

ARANTES, R. Avaliação da acção do pó da folha de oliveira (D-lenolato) em indicadores fisiológicos do murganho. 2008. Dissertação (Mestrado) Departamento de Ciências Veterinárias, Universidade de Trás-os-Montes e Alto Douro, Portugal, 2008. 
ARTAJO, L. et al. Partition of phenolic compounds during the virgin olive oil industrial extraction process. European of Food Research Technology, Heidelberg, v. 225, p. 617-625, 2007.

ASSOCIATION OF OFFICIAL ANALYTICAL CHEMISTIS. Official Methods of Analysis. 11ed. Washington D.C.: A.O.A.C.,1980. 1051p.

ASSOCIAÇÃO DOS OLIVICULTORES DO SUL DO BRASIL - OLISUL. Variedades de Oliveira. Mundo. Disponível em:<http://www.olivicultura-rs.com.br>. Acesso em: 20 mar. 2012. In: CAVALHEIRO, C. V. Extração de compostos fenólicos assistida por ultrassom e determinação de ácidos graxos e minerais em folhas de Olea Europaea L. 2013. Dissertação (Mestrado) - Universidade Federal de Santa Maria, Santa Maria, 2013.

BALKAN ANALYTICAL (2016). Disponível em:<http://www.balkananalytical.com> Acesso em: 21 fev. 2016.

BAO, J. et al. Computational study of bindings of olive leaf extract (OLE) to HIV-1 fusion protein gp41. FEBS letters, Chichester, v. 581, p. 457-462, 2007.

BARÃO, C. E. Inclusão molecular da oleuropeína e do Butil Hidroxianisol (BHA) em Alfa e Beta-Ciclodextrina. 2008. 123 f. Dissertação (Mestrado) - Centro de Technologia, Universidade Estadual de Maringá, Maringá, 2008.

BARRANCO, D.; FERNANDEZ-ESCOBAR, R.; RALLO, L. El cultivo del olivo. 6. ed. Madrid: Ediciones mundi-prensa y junta de Andalucia, 2008. 846 p.

BENAVENTE-GARCIA, O. et al. Antioxidant activity of phenolics extracted from Olea europaea L. leaves. Food Chemistry, Amsterdam, v. 68, p. 457-462, 2000.

BILGIN, M.; SELIN, S. Effects of geographical origin and extraction methods on total phenolic yield of olive tree (Olea europaea) leaves. Journal of the Taiwan Institute of Chemical Engineers, Amsterdam, v. 44, p. 8-12, 2013.

BOSKOU, D. Química y tecnología del aceite de oliva. Madrid: Mundi Prensa, 1998. $295 \mathrm{p}$. 
BOUAZIZ, M. et al. Effect of storage on refined and husk olive oils composition: stabilization by addition of natural antioxidants from chemlali olive leaves. Food Chemistry, Amsterdam, v. 108, p. 253-262, 2008.

BRENNA, O. V.; PAGLIARINI, E. Multivariate analysis of antioxidant power and polyphenolic composition in red wines. Journal of Agricultural and Food Chemistry, Washington, v.49, n.10, p.4841-4, 2001.

BRIANTE, R. et al. Production of highly purified hydroxytyrosol from Olea europaea leaf extract biotransformed by hiperthermophilic $\beta$-glycosidase. Journal of Biotechnology, Amsterdam, v. 111, p. 67-77, 2004.

CABALLERO, J. M. Variedades de oliveiras mais plantadas nos principais países produtores do mundo. In: OLIVEIRA, A. F. (Org.). Oliveira no Brasil: tecnologias de produção. Belo Horizonte: EPAMIG, 2012. cap. 6. p. 159-192.

CÁRCEL, J. A. et al. Food process innovation through new technologies: Use of ultrasound. Journal of Food Engineering, London, v. 110, p. 200-207, 2012.

CASTRO, M. D. L.; GARCIA-AYUSO, L. E. Soxhlet extraction of solid materials: an outdated technique with a promising innovative future. Analytica Chimica Acta, Amsterdam, v. 369, p. 1-10, 1998.

CASTRO, M. D. L.; CAPOTE, F. P. Analytical applications of ultrasound.

Techniques and Instrumentation in Analytical Chemistry, Amsterdam, v. 26, 413 p. 2007.

CASTRO, M. D. L.; CAPOTE, F. P. Soxhlet extraction: Past and present panacea. Journal of Chromatography A, Amsterdam, v. 1217, p. 2383-2389, 2010.

CHAICOUSKI, A. et al. Determinação da quantidade de compostos fenólicos totais presentes em extratos líquido e seco de erva-mate (ilex paraguariensis). Revista Brasileira de Produtos Agroindustriais, João Pessoa, v. 16, n. 1, p. 33-41, 2014.

CHEMAT, F.; HUMA, Z.; KHAN, M. K. Applications of ultrasound in food technology: Processing, preservation and extraction. Ultrasonics Sonochemistry, Amsterdam, v. 18 p. $813-835,2011$. 
$\mathrm{CHIOU}$, A. et al. Retention an distribution of polyphenols after pan-frying of French fries in oils enriched with olive leaf extract. Journal of Food Science, Hoboken, v. 72, p. S574-S584, 2007.

CONFEDERAÇÃO NACIONAL DAS COOPERATIVAS AGRÍCOLAS E DO CRÉDITO AGRÍCOLA DE PORTUGAL - CONFAGRI. Variedades existentes em Portugal. Disponível em:<http://www.confagri.pt>. Acesso em: 20 mar. 2013. In: CAVALHEIRO, C. V. Extração de compostos fenólicos assistida por ultrassom e determinação de ácidos graxos e minerais em folhas de Olea Europaea L. 2013. Dissertação (Mestrado) - Universidade Federal de Santa Maria, Santa Maria, 2013.

COUTINHO, E. F. et al. Mercados e comercialização. In: COUTINHO, E. F.; RIBEIRO, F. C.; CAPPELLARO, T. H. (Orgs.). Cultivo de oliveira (Olea europaea L.). Pelotas: Embrapa Clima Temperado, 2009. p. 102-115.

CRUZ, M. C. M. et al. Botânica, anatomia e ecofisiologia. In: OLIVEIRA, A. F. (Org.). Oliveira no Brasil: tecnologias de produção. Belo Horizonte: EPAMIG, 2012. cap. 5. p. 118-157.

DE BOCK, M. et al. Olive (Olea europaea L.) leaf polyphenols improve insulin sensitivity in middle-aged overweight men: a randomized, placebo-controlled, crossover trial. PLoS One, San Francisco, v. 8, p. e57622, 2013.

DE LEONARDIS, A. et al. Isolation of a hydroxytyrosol-rich extract from olive leaves (Olea Europaea L.) and evaluation of its antioxidant properties and bioactivity.

European Food research and Technology, Heidelberg, v. 226, p. 653-659, 2008.

DIAS, T. P. V. B. et al. Liquid-liquid equilibrium for ternary systems containing ethylic biodiesel + anhydrous ethanol + refined vegetable oil (sunflower oil, canola oil and palm oil): experimental data and thermodynamic modeling. Brazilian Journal of Chemical Engineering, São Paulo, v. 32, n. 3, 2015.

DíEZ, C. M. et al. Centennial olive trees as a reservoir of genetic diversity. Annals of Botany, Oxford, v. 108, n. 5, p. 797-807, 2011.

DUARTE, C. S. C. Extracção e encapsulamento de compostos bioactivos do bagaço de azeitona. 2011. Dissertação (Mestrado) - Universidade Técnica de Lisboa, Lisboa, 2011. 
DURÁN, R. M.; PADILLA, B. Actividad antioxidante de los compuestos fenólicos. Grasas y Aceites, Sevilla, v. 44, n. 2, p. 101-106, 1993.

EFMORFOPOULOU, E.; RODIS. P. Complexation of oleuropein and trans-cinnamic acid with cyclodextrins. Chemistry of Natural Compounds, New York, v. 40, n. 4, p. 362-366, 2004.

EL, S. N.; KARAKAYA, S. Olive tree (Olea europaea) leaves: potential beneficial effects on human health. Nutrition Reviews, Cary, v. 11, n. 67, p. 632-638, 2009.

EMPRESA BRASILEIRA DE PESQUISA AGROPECUÁRIA - EMBRAPA. Embrapa discute a Olivicultura. Disponível em:

<http://www.cpact.embrapa.br/imprensa/noticias/2012/24102012.php>. Acesso em: 06 nov. 2012. In: CAVALHEIRO, C. V. Extração de compostos fenólicos assistida por ultrassom e determinação de ácidos graxos e minerais em folhas de Olea Europaea L. 2013. Dissertação (Mestrado) - Universidade Federal de Santa Maria, Santa Maria, 2013.

EMPRESA DE PESQUISA AGROPECUÁRIA DE MINAS GERAIS - EPAMIG. Cultura da Oliveira (Olea europaea L.). Circular Técnica, Belo Horizonte, n. 150, p. 7, 2002.

ERBAY, Z.; ICIER, F. Optimization of hot air drying of olive leaves using response surface methodology. Journal of Food Engineering, London, v. 91, p. 533-541, 2009.

ERBAY, Z.; ICIER, F. The importance and potential uses of olive leaves. Food Reviews International, New York, v. 26, p. 319-334, 2010.

ESCLAPEZ, M. D. et al. Ultrasound-assisted extraction of natural products. Food Engineering Reviews, New York, v. 3, p. 108-120, 2011.

FALKENBERG, M. B.; SANTOS, R. I.; SIMÕES, C. M. O. Introdução à análise fitoquímica. In: SIMÕES, C. M. O. et al. (Orgs). Farmacognosia: da planta ao medicamento. 6. ed. Porto Alegre: Editora da UFRGS, Florianópolis: Editora da UFSC, 2007. p. 229-245.

FARAG, R.; EL-BAROTY, G.; BASUNY, A. The influence of phenolic extracts obtained from the olive plant (cvs. Picual and Kronakii), on the stability of sunflower oil. International Journal of Food Science and Technology, West Sussex, v. 38, p. 81-87, 2003. 
FARAG, R.; MAHMOUD, E.; BASUNY, A. Use crude olive leaf juice as a natural antioxidant for the stability of sunflower oil during heating. International Journal of Food Science and Technology, West Sussex, v. 42, p. 107-115, 2007.

FARES, R. et al. The antioxidant and anti-proliferative activity of the lebanese Olea europaea extract. Plant Foods for Human Nutrition, New York, v. 66, n. 1, p. 5863, 2011.

FARMER, H. E. et al. The course and mechanism of autoxidation reactions in olefinic and polyolefinic substances, including rubber. Transactions of the Faraday Society, London, v. 38, p. 348-355, 1942.

FERREIRA, I. et al. Antioxidant activity abd phenolic contentes of Olea europaea Lleaves sprayed with diferent copper formulations. Food Chemistry, Amsterdam, v. 103, p. 188-195, 2007.

FRANKEL, E. N. Lipid oxidation. Progress in Lipid Research, Oxford, v. 19, p. 1-22, 1980.

GALANAKIS, C. M.; TORNBERG, E.; GEKAS, V. Recovery and preservation of phenols from olive waste in ethanolic extracts. Journal of Chemical Technology and Biotechnology, Chichester, v. 85, p. 1148-1155, 2010.

GARCIA-SALAS, P. et al. Phenolic Compound Extraction Systems for fruit and vegetable samples. Molecules, Basel, v. 15, p. 8813-8826, 2010.

GAVA, A. J. Princípios da tecnologia de alimentos. São Paulo: Nobel, 2002. $284 \mathrm{p}$.

GHASSEMPOUR, A. et al. Study of new extraction methods for separation of anthocyanins from red grape skins: analysis by HPLC and LC-MS/MS. Journal of Liquid Chromatography and Related Technologies, New York, v. 31, p. 26862703, 2008.

GONÇALVES, P. M. F. Efeitos de metabólitos de fenóis do azeite no dano oxidativo em eritrócitos humanos. 2013. Dissertação (Mestrado) - Faculdade de Ciências, Universidade do Porto, 2013.

GORDON, M. H.; PAIVA-MARTINS, F.; ALMEIDA, M. Antioxidant activity of hydroxytyrosoll acetate compared with other olive oil polyphenols. Journal of Agricultural and Food Chemistry, Washington, v. 49, p. 2480-2485, 2001.

HADORN, H.; ZURCHER, K. Zur bestimmung der oxydationsstabilitat von olen und fetten. Deutsche Lebensmittel Rundschau, Hamburg, v. 70, n. 2, p. 57-65, 1974. 
HALOUI, E. et al. Pharmacological activities and chemical composition of the Olea europaea L. leaf essential oils from Tunisia. Journal of Food Agriculture and Environment, Helsinki, v. 8, p. 204-208, 2010.

HASSEN, I.; CASABIANCA, H.; HOSNI, K. Biological activities of the natural antioxidant oleuropein: Exceeding the expectation - a mini review. Journal of Functional Foods, Amsterdam, v. 18, p. 926-940, 2015.

HERRERO, M.; CIFUENTES, A.; IBAÑEZ, E. Sub- and supercritical fluid extraction of functional ingredients from different natural sources: plants, food-byproducts, algae and microalgae. Food Chemistry, Amsterdam, v. 98, p. 136-148, 2006.

HOCHKOEPPLER, A.; KOFOD, P.; ZANNONI, D. HIPIP oxidoreductase activity in membranes from aerobically grown cells of facultative phototroph rhodoferax fermentants. FEBS letters, Chichester, v. 375, p. 197-200, 1995.

IGNAT, I.; VOLF, I.; POPA, V. I. A critical review of methods for characterisation of polyphenolic compounds in fruits and vegetables. Food Chemistry, Amsterdam, v. 126, p. 1821-1835, 2011.

INSTITUTO ADOLFO LUTZ. Métodos físico-químicos para análise de alimentos. São Paulo: Instituto Adolfo Lutz, 2008. 1020 p.

PAQUOT, C. Standard methods for the analysis of oils, fats and derivatives. 6 . ed. Oxford: Pergamon Press, 1979. part 1 (sections I and II).

JAPÓN-LUJÁN, R.; LUQUE-RODRÍGUEZ, J. M.; LUQUE DE CASTRO, M. D. Dynamic ultrasound-assisted extraction of oleuropein and related biophenols from olive leaves. Journal of Chromatography A, Amsterdam, v. 1108, p. 76-82, 2006.

JAPÓN-LUJÁN, R.; CASTRO, M. D. L. Small branches of olive tree: a source of biophenols complementary to Olive Leaves. Journal of Agricultural and Food Chemistry, Washington, v. 55, p. 4584-4588, 2007.

JAPON-LUJAN, R.; LUQUE DE CASTRO, M.D. Liquid-liquid extraction for the enrichment of edible oils with phenols from olive leaf extracts. Journal of Agricultural and Food Chemistry, Washington, v. 56, p. 2505-2511, 2008. 
JIMENEZ, P. et al. Oxidative stability of oils containing olive leaf extracts obtained by pressure, supercritical and solvent-extraction. European Journal of Lipid Science and Technology, Weinheim, v. 113, p. 497-505, 2011.

JORGE, R. O. Caracterização de azeites virgem extra "gourmet" varietais e "blends" comercializados no mercado do rio grande do sul. 2010. $103 \mathrm{f}$. Tese (Doutorado) - Faculdade de Agronomia Eliseu Maciel, Universidade Federal de Pelotas, Pelotas, 2010.

KAJDZANOSKA, M.; PETRESKA, J.; STEFOVA, M. J. Comparison of different extraction solvente mixtures for characterization of phenolic compounds in strawberries. Journal of Agricultural and Food Chemistry, Washington, v. 59, p. 5272-5278, 2011

KIRITSAKIS, K. et al. Composition and antioxidant activity of olive leaf extracts from greek olive cultivars. Journal of the American Oil Chemists' Society, Heidelberg, v. 87, n. 4 , p. 369-376, 2010.

KLEJDUSA, B. et al. Solid- phase/supercritical- fluid extraction for liquid chromatography of phenolic compounds in fresh water microalgae and selected cyanobacterial species. Journal of Chromatography A, Amsterdam, v. 1216, p. 763-771, 2009.

KRICHENE, D. et al. Stability of virgin olive oil and behaviour of its natural antioxidants under medium temperature accelerated storage conditions. Food Chemistry, Amsterdam, v. 121, p. 171-177, 2010.

LALAS, S. et al. Enrichment of table olives with polyphenols extracted from olive leaves. Food Chemistry, Amsterdam, v. 127, p. 1521-1525, 2011.

LANG, Q.; WAI, C. M. Supercritical fluid extraction in herbal and natural product studies - a pratical review. Talanta, Amsterdam, v. 53, p. 771-782, 2001.

LE TUTOUR, B.; GUEDON, D. Antioxidant activities of Olea europaea leaves and related phenolic compounds. Phytochemistry, Kidlington, v. 31, p. 1173-1178, 1992.

LIMA, R. M. F.; LUZ, J. A. M. Análise granulométrica por técnicas que se baseiam na sedimentação gravitacional: Lei de Stokes. Revista da Escola de Minas, Ouro Preto, v. 54, n. 2, 2001. 
LOPES, P. S. Viveiros de oliveiras. Disponível em:

<http://soareslopes.tripod.com >. Acesso em: 20 fev. 2016.

LOZANO-SÁNCHEZ, J. et al. Recovering bioactive compounds from olive oil filter cake by advanced extraction techniques. International Journal of Molecular Sciences, Basel, v. 15, n. 9, p. 16270-16283, 2014.

LUQUE-GRACIA, J. L.; CASTRO, M. D. L. Ultrasound: a powerful tool for leaching. Trends in Analytical Chemistry, Amsterdam, v. 22, n. 1, 2003.

MARTíNEZ-VALVERDE, I.; PERIAGO, M. J.; ROS, G. Nutritional importance of phenolic compounds in the diet. Archivos Latinoamericanos de Nutricion, Caracas, v. 50, p. 5-18, 2000.

MARTINS, F. P.; GORDON, M. Enriched refined olive oil with olive tree phenolic compounds. In: ENCONTRO DE QUIMICA DE ALIMENTOS, 7., 2005, Viseu.

Anais... Viseu, 2005.

MARTINS, F. P.; PINTO, M. Isolation and Characterization of a new hydroxytyrosol derivative from olive (Olea europaea) leaves. Journal of Agricultural and Food Chemistry, Washington, v. 56, p. 5582-5588, 2008.

MASON, T. J.; PANIWNYK, L.; LORIMER, J. P. The uses of ultrasound in food 554 technology. Ultrasonics Sonochemistry, Amsterdam, v. 3, p. 253-260, 1996.

MERDASSA, Y.; LIU, J.; MEGERSA, N. Development of a one-step microwaveassisted extraction procedure for highly efficient extraction of multiclass fungicides in soils. Analytical Methods, Cambridge, v. 6, p. 3025-3033, 2014.

MICOL, V. et al. The olive leaf extract exhibits antiviral activity against viral haemorrhagic septcaemia rhabdovirus (VHSV). Antiviral Research, Amsterdam, v. 66, p. 129-136, 2005.

MILIC, P. S. et al. Kinetic modeling and optimization of maceration and ultrasoundextraction of resinoid from the aerial parts of white lady's bedstraw (Galium mollugo L.). Ultrasonics Sonochemistry, Amsterdam, v. 20, p. 525-534, 2013.

MIRANDA, J. L. et al. Olive oil and health: Summary of the II international conference on olive oil and health consensus report, Jaén and Córdoba (Spain) 2008. Nutrition, Metabolism and Cardiovascular Diseases, Oxford, v. 20, p. 284-294, 2010. 
MKAOUAR, S. et al. Instant controlled pressure drop texturing for intensifying ethanol solvent extraction of olive (Olea europaea) leaf polyphenols. Separation and

Purification Technology, Kidlington, v. 145, p. 139-146, 2015.

MOSCA, M. et al. Role of emulsifier layer, antioxidants and radical initiators in the oxidation of olive oil-in-water emulsions. Food Research International, Kidlington, v. 50, p. 377-383, 2013.

MUSTAFA, A.; TURNER, C. Pressurized liquid extraction as a green approach in food and herbal plants extraction: a review. Analytica Chimica Acta, Amsterdam, v. 703, p. 8-18, 2011.

NAWAR, W. W.; FENNEMA, O. R. (Eds.). Lipids. New York: Marcel Dekker, 1985. $139 \mathrm{p}$.

PACETTA, C. F. Estudos de diferentes metodologias para a obtenção de extratos de folhas de oliveira (Olea europaea) contendo oleuropeína. 2013. $82 \mathrm{f}$. Dissertação (Mestrado) - Faculdade de Zootecnia e Engenharia de Alimentos, Universidade de São Paulo, Pirassununga, 2013.

PAIVA-MARTINS, F.; GORDON, M. H. Isolation and characterization of the Antioxidant Component 3, 4-Dihydroxyphenylethyl 4-formyl-3-formylmethyl4-hexenoate from Olive (Olea europaea) leaves. Journal of Agriculture and Food Chemistry, Washington, v. 49, p. 4214-4219, 2001.

PAIVA-MARTINS, F. et al. Effects of enrichment of refined olive oil with phenolic compounds from olive leaves. Journal of Agricultural and Food Chemistry, Washington, v. 55, p. 4139-4143, 2007.

PEDROSA, S. S. S. Análise dos componentes do azeite utilizando métodos quimiométricos. 2010. Dissertação (Mestrado) - Departamento de Química, Universidade de Aveiro, Aveiro, 2010.

PEREIRA, A. et al. Phenolic compounds and antimicrobial activity of olive (Olea europaea L. Cv. Cobrançosa) leaves. Molecules, Basel, v. 12, p. 1153-1162, 2007.

PEREZ-JIMENEZ, F. et al. International conference on the healthy effect of virgin olive oil. European Journal of Clinical Investigation, Chichester, v. 35, p. 421-424, 2005. 
POKORNY, J. Natural antioxidants for food use. Trends Food Science

Technology, Kidlington, v. 2, p. 223-227, 1991.

PRAKASH, L.; MAJEED, M. Natural ingredients for anti-ageing skin care. Household Personal Care, v. 2, p. 44-46, 2009.

PRONIK, C.; MAZZA, G. Design and scale-up of pressurized fluid extractors for food and bioproducts. Journal of Food Engineering, London, v. 95, p. 215-226, 2009.

RAFECAS, M. et al. Liquid chromatographic determination of phenolic antioxidants in bakery products. Journal of Chromatography A, Amsterdam, v. 822, n. 2, p. 305-309, 1998.

RAMALHO, V. C.; JORGE, N. Antioxidantes utilizados em óleos, gorduras e alimentos gordurosos. Química Nova, São Paulo, v. 29, n. 4, p. 755-760, 2006.

RANALLI, A. et al. Factors Affecting the contents of iridoid oleuropein in Olive Leaves (Olea europaea L.). Journal of Agricultural and Food Chemistry, Washington, v. 54, p. 434-440, 2006.

REVERCHON, E.; DE MARCO, I. Supercritical fluid extraction and fractionation of natural matter. Journal Supercritical Fluids, Amsterdam, v. 38, p. 146-166, 2006.

RIACHY, M. E. et al. Hydrophilic antioxidants of virgin olive oil. Part 1: hydrophilic phenols: a key factor for virgin olive oil quality. European Journal of Lipid Science and Technology, Weinheim, v. 113, p. 678-691, 2011.

RICHTER, B. E. et al. Accelerated solvent extraction: a new technique for sample preparation. Analytical Chemistry, Rajkot, v. 68, p. 1033-1039, 1997.

RYAN, D.; ROBARDS, K.; LAVEE, S. Phenolic compounds in olives: critical review. The Analyst, Cambridge, v. 123, p. 31R-44R, 1999.

SAHIN, S.; BILGIN, M.; DRAMUR, M. U. Investigation of oleuropein content in Olive Leaf extract obtained by supercritical fluid extraction and soxhlet methods.

Separation Science and Technology, Philadelphia, v. 46, p. 1829-1837, 2011. 
SALTA, F. N. et al. Oxidative stability of edible vegetable oils enriched in polyphenols with olive leaf extract. Food Science and Technology International, London, v. 13, p. 413-421, 2007.

SAVOURNIN, C. et al. Rapid high-performance liquid chromatography analysis for the, quantitative determination of oleuropein in Olea europaea Leaves. Journal Agriculture and Food Chemistry, Amsterdam, v. 49, p. 619-621. 2001.

SCHARLACK, N. K. Estudo do efeito do tipo e grau de hidratação de solventes alcoólicos na extração simultânea de óleo e ácidos clorogênicos de torta de sementes de girassol. 2015. 126 f. Dissertação (Mestrado) - Faculdade de Zootecnia e Engenharia de Alimentos, Universidade de São Paulo, Pirassununga, 2015.

SHIRSATH, S. R.; SONAWANE, S. H.; GOGATE, P. R. Intensification of extraction of natural products using ultrasonic irradiations - a review of current status. Chemical Engineering and Processing, Amsterdam, v. 53, p.10-23, 2012.

SIGMA ALDRICH - A Part of Millipore Sigma. Disponível em: <https://www.sigmaaldrich.com/united-states.html >. Acesso em: 10 abril. 2016.

SILVA, S. et al. Phenolic Compounds and Antioxidant Activity of Olea europaea L. Fruits and Leaves. Food Science and Technology International, London, v. 12, n. 5, p. 385-395, 2006.

SIMIC, M. G.; JAVANOVIC, S. V. Inactivation of oxygen radicals by dietary phenolic compounds in anticarcinogenesis. In: HO, C. T.; OSAWA, T.; HUANG, T. M.; ROSEN, R. T. (Eds.). Food phytochemicals for cancer prevention. Washington: American Chemical Society, 1994, p. 20.

SOARES LOPES (2015). Disponível em:<http://soareslopes.tripod.com>. Acesso em: 10 dez. 2015.

SONAGLIO, D. et al. Desenvolvimento tecnológico e produção de fitoterápicos. In: SIMÕES, C. M. O. et al. Farmacognosia da planta ao medicamento. Porto Alegre, Brazil: Editora da UFRG/ Editora da UFSC. 2007. p. 289-326.

STAMATOPOULOUS, $\mathrm{K}$ et al. Optimization of multistage extraction of Olive Leaves for recovery of phenolic compounds at moderated temperatures and short extraction times. Foods, Basel, v. 3, p. 66-81, 2014. 
SUMIYOSHI, M.; KIMURA, Y. Effects of Olive Leaf extract and its main component oleuroepin on acute ultraviolet b irradiation-induced skin changes in C57BL/6J Mice. Phytotherapy Research, Chichester, v. 24, p. 995-1003, 2010.

TASIOULA-MARGARI, M.; OLOGERI, O. Isolation and characterization of virgin olive oil phenolic compounds by HPLC/UV and GC/MS. Journal of Food Science, Hoboken, v. 66, p. 530-534, 2001.

TAAMALI, A. et al. Use of advanced techniques for the extraction of phenolic compounds from Tunisian olive leaves: phenolic composition and cytotoxicity against human breast cancer cells. Food and Chemical Toxicology, Kidlington, v. 50, p. 1817-1825, 2012.

TAN, H. W. et al. Simultaneous determination of oleuropein and hydroxytyrosol in rat plasma using liquid chromatography with fluorescence detection. Journal of Chromatography B, Amsterdam, v. 191, p. 785-187, 2003.

TSIMIDOU, M.; BOSKOU, D. Antioxidant activities of essential oils from the plants of the Lamiaceae family. In: CHARALAMBOUS, G. Spices, herbs and edible fungi. Amsterdam: Elsevier, 1994. p. 273-284.

TRIPOLI, E. et al. The phenolic compounds of olive oil: structure, biological activity and beneficial effects on human health. Nutrition Research Reviews, Cambridge, $v$. 18, p. 98-112, 2005.

VALERO, M. et al. Effects of 624 ultrasonic treatments in orange juice processing. Journal of Food Engineering, London, v. 80, p. 625 509-516, 2007.

VEILLET, S.; TOMAO, V.; CHEMAT, F. Ultrasound assisted maceration: An original procedure for direct aromatization of olive oil with basil. Food Chemistry, Amsterdam, v. 123, p. 905-911, 2010.

VINATORU, M. et al. The use of ultrasound for the extraction of bioactive principles from plant materials. Ultrasonics Sonochemistry, Amsterdam, v. 4, p. 135-139, 1997.

VILLA, F.; OLIVEIRA, A. F. Origem e expansão da oliveira na América Latina. In: OLIVEIRA, A. F. (Org.). Oliveira no Brasil: tecnologias de produção. Belo Horizonte: EPAMIG, 2012. cap. 1. p. 21-38. 
VILKHU, K. et al. Applications and opportunities for ultrasound assisted extraction in the food industry - a review. Innovative Food Science and Emerging Technologies, Amsterdam, v. 9, p. 161-169, 2008.

VISIOLI, F.; BELLOSTA, S.; GALLI, C. Oleuropein, the bitter principle of olives, enhances nitric oxide production by mouse macrophages. Life Sciences, The Hague, v. 62, p. 541-546, 1998.

VISIOLI, F.; POLI, A.; GALLI, C. Antioxidant and other biological activities of phenols from olives and olive oil. Medicinal Research Review, Hoboken, v. 22, p. 65-75, 2002.

WALTER, W. M.; FLEMING, H. P.; ETCHELLS, J. P. Preparation of antimicrobial compounds by hidrolysis of oleuropein from green olives. Applied Microbiology, Washington, v. 26, n. 5, p. 773-779, 1973.

XYNOS, N. et al. Development of a green extraction procedure with super/subcritical fluids to produce extracts enriched in oleuropein from olive leaves. The Journal of Supercritical Fluids, Amsterdam, v. 67, p. 89-93, 2012.

$\mathrm{XIE}, \mathrm{P}$. et al. Reduced pressure extraction of oleuropein from olive leaves (Olea europaea L.) with ultrasound assistance. Food and Bioproducts Processing, London, v. 93, p. 29-38, 2013.

YANG Y.; ZHANG F. Ultrasound-assisted extraction of rutin and quercetin from Euonymus alatus (Thunb.). Ultrasonics Sonochemistry, Amsterdam, v. 15, p. 308313, 2008.

ZENEBON, O.; PASCUET, N. S.; TIGLEA, P. Métodos físico-químicos para análise de alimentos. São Paulo: Instituto Adolfo Lutz, 2008, p. 148-154.

ZOIDOU, E. et al. Oleuropein as a bioactive constituent added in milk and yogurt. Food Chemistry, Amsterdam, v. 158, p. 319-324, 2014. 